\title{
The fossil Osmundales (Royal Ferns) - a phylogenetic network analysis, revised taxonomy, and evolutionary classification of anatomically preserved trunks and rhizomes
}

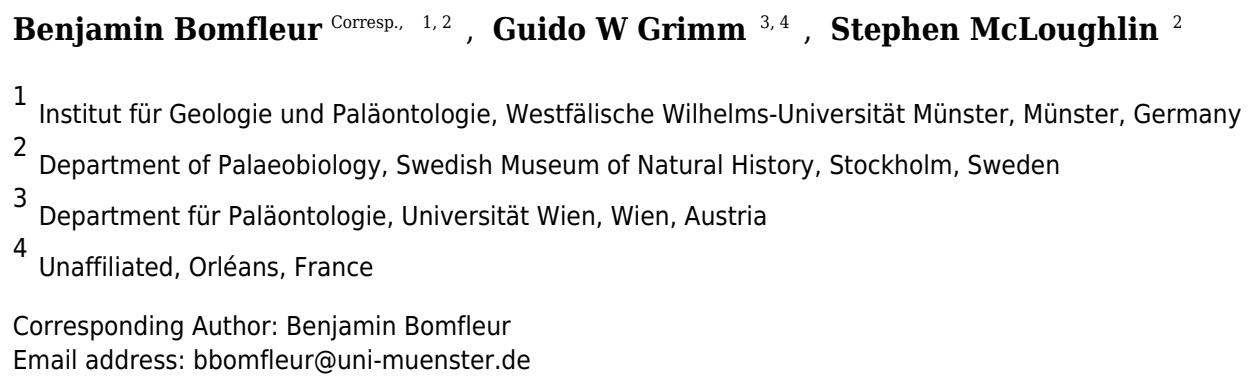

The Osmundales (Royal Fern order) originated in the late Palaeozoic and is the most ancient surviving lineage of leptosporangiate ferns. In contrast to its low diversity today (less than 20 species in six genera), it has the richest fossil record of any extant group of ferns. The structurally preserved trunks and rhizomes alone are referable to more than 100 fossil species that are classified in up to twenty genera, four subfamilies, and two families. This diverse fossil record constitutes an exceptional source of information on the evolutionary history of the group from the Permian to the present. However, inconsistent terminology, varying formats of description, and the general lack of a uniform taxonomic concept renders this wealth of information poorly accessible. To this end, we provide a comprehensive review of the diversity of structural features of osmundalean axes under a standardized, descriptive terminology. A novel morphological character matrix with 45 anatomical characters scored for 15 extant species and for 114 fossil operational units (species or specimens) is analysed using networks in order to establish systematic relationships among fossil and extant Osmundales rooted in axis anatomy. The results lead us to propose an evolutionary classification for fossil Osmundales and a revised, standardized taxonomy for all taxa down to the rank of (sub)genus. We introduce several nomenclatural novelties: (1) a new subfamily Itopsidemoideae (Guaireaceae) is established to contain Itopsidema, Donwelliacaulis, and Tiania; (2) the thamnopteroid genera Zalesskya, legosigopteris, and Petcheropteris are all considered synonymous with Thamnopteris; (3) twelve species of Millerocaulis and Ashicaulis are assigned to modern genera (tribe Osmundeae); (4) the hitherto enigmatic Aurealcaulis is identified as an extinct subgenus of Plenasium; and (5) the poorly known Osmundites tuhajkulensis is assigned to Millerocaulis. In addition, we consider Millerocaulis stipabonettiorum a possible member of Palaeosmunda and Millerocaulis estipularis as probably constituting the earliest 
representative of the (Todea-)Leptopteris lineage (subtribe Todeinae) of modern Osmundoideae. 
1 The fossil Osmundales (Royal Ferns) — a phylogenetic network analysis,

2 revised taxonomy, and evolutionary classification of anatomically

3 preserved trunks and rhizomes

4 Benjamin Bomfleur ${ }^{1,2 *}$, Guido W. Grimm ${ }^{3,4}$, Stephen McLoughlin ${ }^{2}$

5 'Institut für Geologie und Paläontologie, Westfälische Wilhelms-Universität Münster, Münster,

6 Germany

$7 \quad{ }^{2}$ Department of Palaeobiology, Swedish Museum of Natural History, Stockholm, Sweden

$8{ }^{3}$ Department für Paläontologie, Universität Wien, Wien, Austria

9 4Present address: Unaffiliated, Orléans, France

$10{ }^{*}$ Corresponding author

11 Email addresses:

12 BB: bbomfleur@uni-muenster.de; benjamin.bomfleur@nrm.se

13 GWG: grimmiges@gmail.com

14 SM: steve.mcloughlin@nrm.se 
15 Abstract. The Osmundales (Royal Fern order) originated in the late Palaeozoic and is the most 16 ancient surviving lineage of leptosporangiate ferns. In contrast to its low diversity today (less

17 than 20 species in six genera), it has the richest fossil record of any extant group of ferns. The 18 structurally preserved trunks and rhizomes alone are referable to more than 100 fossil species that are classified in up to twenty genera, four subfamilies, and two families. This diverse fossil record constitutes an exceptional source of information on the evolutionary history of the group

21 from the Permian to the present. However, inconsistent terminology, varying formats of

22 description, and the general lack of a uniform taxonomic concept renders this wealth of

23 information poorly accessible. To this end, we provide a comprehensive review of the diversity

24 of structural features of osmundalean axes under a standardized, descriptive terminology. A

25 novel morphological character matrix with 45 anatomical characters scored for 15 extant species 26 and for 114 fossil operational units (species or specimens) is analysed using networks in order to 27 establish systematic relationships among fossil and extant Osmundales rooted in axis anatomy.

28 The results lead us to propose an evolutionary classification for fossil Osmundales and a revised, 29 standardized taxonomy for all taxa down to the rank of (sub)genus. We introduce several 30 nomenclatural novelties: (1) a new subfamily Itopsidemoideae (Guaireaceae) is established to 31 contain Itopsidema, Donwelliacaulis, and Tiania; (2) the thamnopteroid genera Zalesskya,

32 Iegosigopteris, and Petcheropteris are all considered synonymous with Thamnopteris; (3) twelve 33 species of Millerocaulis and Ashicaulis are assigned to modern genera (tribe Osmundeae); (4)

34 the hitherto enigmatic Aurealcaulis is identified as an extinct subgenus of Plenasium; and (5) the 35 poorly known Osmundites tuhajkulensis is assigned to Millerocaulis. In addition, we consider 36 Millerocaulis stipabonettiorum a possible member of Palaeosmunda and Millerocaulis 
37 estipularis as probably constituting the earliest representative of the (Todea-)Leptopteris lineage

38 (subtribe Todeinae) of modern Osmundoideae.

\section{Introduction}

40 The Royal Ferns (Osmundales) form the most ancient surviving lineage of leptosporangiate

41 ferns. The order comprises about twenty extant species originally placed in three or four genera

42 with four (three) subgenera. The recently published, first comprehensive classification of the

43 Pteridophyte Phylogeny Group (PPG) recognizes all former subgenera of Osmunda as distinct

44 genera (PPG I, 2016). Osmundales has arguably the richest and most informative fossil record of

45 any extant group of ferns (e.g., Arnold, 1964; Miller, 1971; Tidwell \& Ash, 1994). Detached

46 fertile foliage (e.g., Anomopteris Brongn., 1828, Todites Seward, 1900, Cladotheca T.Halle,

47 1911, Osmundopsis T.M.Harris, 1931, Cacumen Cantrill \& J.A.Webb, 1987, and Osmunda L.,

48 1753, and possibly Damudopteris D.D.Pant \& P.K.Khare, 1974 and Dichotomopteris Maithy,

49 1974), together with morphologically similar sterile fronds (e.g., Cladophlebis Brongn., 1849)

50 and dispersed spores (e.g., Osmundacidites Couper, 1953, Todisporites Couper, 1958), are

51 probably the most common organs of Osmundales in the fossil record but, in many cases, these

52 remains are difficult to discriminate with confidence from other fern orders. Moreover, foliage

53 adpressions and spores typically lack the character resolution necessary for confident attribution

54 to families and genera within Osmundales (Escapa \& Cúneo, 2012). Anatomically preserved

55 trunks and rhizomes of Osmundales occur in the fossil record since the Permian (matching the

56 stratigraphic range of fossil foliage and spores), and show an extraordinary taxic and structural

57 diversity (e.g., Arnold, 1964; Miller, 1971; Tidwell \& Ash, 1994; Tian et al., 2008; Wang et al.,

58 2014b; Supplemental Figure S1). The most comprehensive and detailed synthesis of the fossil 
59 record of osmundalean rhizomes remains C. N. Miller's (1971) 'Evolution of the fern family

60 Osmundaceae based on anatomical studies'. Miller compiled, analysed, and evaluated an

61 unparalleled amount of data on the axis structure of most extant and all fossil Osmundaceae

62 known at that time, and provided systematic descriptions and taxonomic treatments for all

63 included taxa in a standardized format; he also carefully designed and analysed character

64 matrices in order to reconstruct the phylogenetic history of the group from the Permian to the

65 present. However, since that time, well over 50 additional species, twelve new genera, four new

66 subfamilies, and one new family of Osmundales have been established based on new finds or

67 alternative interpretations of permineralized axes alone (see reviews of, e.g., Tidwell \& Ash,

68 1994; Tian et al., 2008; Wang et al., 2014b; Supplemental Figure S1). Hence, our knowledge

69 about the diverse structural architectures in osmundalean axes has advanced considerably,

70 providing a sound basis for a re-evaluation of the significance of anatomical features for

71 taxonomic delimitation and systematic classification. Unfortunately, not all subsequent authors

72 adopted Miller's standardized terminology and format of description; consequently, studies of

73 the anatomy of fossil Osmundales are riddled with inconsistent terminology and taxonomy,

74 which renders any attempt at an exhaustive analysis problematic.

75 Here, we present and discuss the results of a novel systematic-phylogenetic analysis of 129

76 osmundalean axes, including all currently known fossil records (accepted species plus synonyms

77 and additional separately described specimens) plus 14 extant representatives. We briefly review

78 the diversity of anatomical features of osmundalean axes using a revised, uniform, descriptive

79 terminology, and introduce a new morphological character matrix consisting of 45 architectural

80 characters of the plant axis. The matrix serves two main purposes: the standardized description

81 and identification of specimens and the characterisation of natural groups. The latter incorporates 
82 results of customized phylogenetic network analyses of this matrix. Based on these results, we

83 propose an anatomy-based classification for fossil Osmundales that is as natural as possible, with

84 a revised and standardized taxonomy listing diagnostic axis characters for all taxa down to the

85 rank of (sub)genus. For practicality, we also accept several explicitly paraphyletic taxa as valid

86 taxonomic units. Appendices provide the formal taxonomic treatments of nomenclatural

87 novelties (Appendix A), a glossary of terms and abbreviations (Appendix B), a polytomous

88 identification key (Appendix C), and a tutorial and example analysis (Supplemental File S5) to

89 aid the taxonomic placement of future discoveries of fossil Osmundales axes.

\section{Axis anatomy in Osmundales-a critical reappraisal}

91 Osmundalean axes range from small, creeping or shortly erect rhizomes to huge, arborescent

92 trunks, and they display a remarkable diversity in anatomical structure. Features that are

93 common to all osmundalean axes — extant and extinct — include (1) radial symmetry; (2) helical

94 phyllotaxis; (3) a central cylindrical stele; (4) a single peripheral metaxylem siphon surrounding

95 the stem core; and (5) a single, primarily C-shaped (i.e., adaxially concave), entire vascular

96 bundle in the base of the stipe (Fig. 1). Most osmundalean stems have a prominent cortex (except

97 species of Osmundacaulis) and are surrounded by a prominent mantle of roots and persistent

98 stipe bases (except some Guaireaceae).

99 Stem core

100 In Guaireaceae and in most Osmundaceae, the stem core consists primarily of a parenchymatous

101 pith, in some cases with varying amounts of additional sclerenchyma and, more rarely, tracheids

102 or 'medullary traces'; in thamnopteroid Osmundaceae, the stem core is composed of tracheids 
103 that may be short, elongated, or enlarged and 'parenchyma-like' (Fig. 2). Thus, three basic types

104 have traditionally been described to occur in Osmundales: 'protosteles' (characterizing subfamily

105 Thamnopteroideae) and more-or-less modified 'siphonosteles' and 'dictyosteles' (characterizing

106 subfamily Osmundoideae and family Guaireaceae, respectively).

107 This classification, however, falls short of recognizing that the stele of thamnopteroid

108 Osmundaceae is neither a true protostele (like those of Grammatopteris and Rastropteris,

109 considered by some authors to be ancient relatives of Osmundales) nor a true siphonostele, but

110 rather an intermediate between the two (Fig. 2): it lacks a true parenchymatous pith yet has a

111 distinct peripheral metaxylem siphon that can be entire or perforated just like those of other

112 Osmundales. We consider this shared presence of a distinct peripheral metaxylem siphon in all

113 Osmundales as more significant than the variable tissue composition of the stem core: in the

114 latter, a gradual transition can be drawn from long tracheids (Thamnopteris gracilis) to short

115 parenchyma-like tracheids (most Thamnopteroideae) to short tracheids with interspersed

116 parenchyma (Thamnopteris kidstonii) to parenchyma with interspersed tracheids (e.g.,

117 Millerocaulis lutziae, M. kolbei, Claytosmunda beardmorensis) to parenchyma (and secondary

118 sclerenchyma; most Osmundoideae) to fully sclerified stem cores (e.g., Todea) (Fig. 2). Thus,

119 the stele type of thamnopteroid Osmundaceae corresponds structurally and functionally to a

120 siphonostele, regardless of the varying proportions of tracheids or parenchyma it contains.

121 Current terminology and classification of stele architectures does not cover such a type (see

122 Schmid, 1982), and we contend that a descriptive terminology should be used instead of

123 categorical classification in the systematic description of these stele types: "Stem core consisting

124 of $[\ldots]$ ". as opposed to, e.g., "Stem protostelic". 
125 Stele

126 The stele of all Osmundales is characterized by a distinct, peripheral metaxylem siphon (Figs 1,

127 3). Whereas in a few species of Thamnopteroideae this siphon may appear completely entire and

128 uninterrupted throughout its length (e.g., T. kidstonii), the departing leaf traces usually leave

129 more or less prominent notches or gaps in the stele periphery (Fig. 3). Furthermore, a protoxylem

130 cluster in the stele may become associated with a parenchyma pocket that increases in size

131 distally and that may eventually break through towards the pith before the leaf trace departs the

132 stele, thus creating a deep notch or embayment along the internal margin of the stele; in these

133 cases, a given stem transverse section may show one or more inverse U-shaped (parts of) xylem

134 segments with the openings directed toward the pith (e.g., Chasmatopteris principalis;

135 Osmundoideae; Osmundacaulis spp.; Fig. 3).

136 Traditionally, the stems of Thamnopteroideae have been described as having a gapless and

137 imperforate stele consistent with their classification as being protostelic (see, e.g., Wang et al.,

138 2014b). In most thamnopteroids, however, the departure of a leaf trace does leave a noticeable

139 gap in the form of at least a shallow peripheral incision in the external surface of the metaxylem

140 siphon (e.g., Thamnopteris schlechtendahlii). In Chasmatopteris principalis, this incision may

141 even perforate the xylem siphon completely; thus, except for its stem core consisting presumably

142 of enlarged tracheids rather than parenchyma, the stele of Chasmatopteris equates to the

143 'dictyoxylic siphonostele' found in most other Osmundoideae.

144 The degree of perforation of the metaxylem siphon is commonly used as a diagnostic

145 feature in taxonomic treatments of Osmundales (e.g., Miller, 1971; Tidwell \& Ash, 1994; Tian et

146 al., 2008; Wang et al., 2014b), but authors disagree about the significance of this character (see

147 Vera, 2008; Herbst, 2015). In Osmundales, the stele perforation embraces a continuous 
148 spectrum, ranging from a simple, straight, imperforate tube (e.g., Thamnopteris kidstonii) to a

149 highly complex, reticulate network of stelar xylem segments (e.g., Osmundacaulis, Lunea; Fig.

150 3; Supplemental Table S1). Whereas classification of end members in this spectrum is rather

151 straightforward, the range of variation represented - especially in the diverse array of Mesozoic

152 osmundoid rhizomes - makes a categorical classification difficult (Vera, 2008). This is further

153 complicated by the fact that the development of complete perforations in the xylem cylinder

154 depends on the ontogenetic stage of the individual specimen and on the level at which it is

155 sectioned (Vera, 2008; see also Seward \& Ford, 1903; Wardlaw, 1946, 1947; Hewitson, 1962;

156 Gould, 1970; Cantrill, 1997; Herbst, 2001, 2006; Fig. 4). In addition, the presence of complete

157 leaf-gap perforations may be obscured by taphonomic effects (Kidston \& Gwynne-Vaughan,

158 1907: 760), or perforations may be so short or transect the stele at such an acute angle that no

159 single transverse section of the xylem siphon will show a complete perforation (e.g., Sharma,

160 1973; Vera, 2008; see also Fig. 4).

161 We agree with Vera (2008) that the degree of stele perforation should not be emphasized as

162 a character for generic distinction within Osmundoideae. Considering Osmundales as a whole,

163 highly perforate steles certainly evolved more than once, but are nonetheless characteristic of

164 particular lineages within the Osmundaceae (e.g., Osmundacaulis, Plenasium subgenus

165 Aurealcaulis in Osmundoideae) and Guaireaceae (Guairea in Guaireoideae). This applies also to

166 the opposite extreme: (nearly) imperforate steles are characteristic of Thamnopteroideae in

167 Osmundaceae and of Itopsidemoideae in Guaireaceae. Finally, we argue that an unusually high

168 degree of perforation can also be characteristic of a particular species or even genus within a

169 group with otherwise imperforate or only moderately perforated steles (consider, e.g., the highly

170 perforated stele of Millerocaulis kolbei or the perforate stele of Chasmatopteris in 
171 Thamnopteroideae). Altogether, the significance of the degree of stele perforation depends on the

172 context of the individual fossil and its putative relatives.

173 The peripheral xylem siphon usually measures 10 to 20 , rarely up to 25 tracheid cells in

174 radial thickness; exceptions to this rule are Guairea, Donwelliacaulis, and Osmundacaulis, in

175 which the siphon is particularly thick and ranges from about 30 to, in extreme cases

176 (Donwelliacaulis, Osmundacaulis pruchnickii), more than 70 cells in radial thickness

177 (Supplemental Table S1). In nearly all Osmundales, the siphon consists of metaxylem tracheids

178 with more-or-less evenly distributed protoxylem poles in mesarch or subexarch position; in many

179 taxa, developing leaf-trace protoxylem clusters become associated distally with pockets of

180 parenchyma. In this respect, Itopsidema, Donwelliacaulis, and Tiania (Guaireaceae:

181 Itopsidemoideae) are unique in that the peripheral xylem siphon consists of a spongy admixture

182 of xylem tracheids with diffusely interspersed 'nests' of parenchyma that are not immediately

183 related to protoxylem clusters of early-developing leaf traces (dotted xylem signature in Fig. 3).

184 Endodermis and phloem are usually only external to the stele. In some taxa, they may

185 occur also internally, and even connect through leaf gaps and completely ensheath individual

186 xylem segments in a given stem transverse section. In these latter types, cortical tissues may then

187 invaginate through the leaf gaps into the pith (or vice versa). Such particularly complex stele

188 types have been referred to as 'dissected-siphonostelic' (in cases where endodermal layers

189 connect) and 'dictyostelic' (in cases where phloem layers connect) (see Miller, 1971). This

190 differentiation, however, is difficult to use for the classification of extant and extinct

191 Osmundales; in many fossils, imperfect preservation makes it difficult to distinguish between

192 phloem, endodermis and cortical parenchyma and, hence, to identify siphonostelic, dissected-

193 siphonostelic, and dictyostelic conditions (Herbst, 2015). Furthermore, anatomical studies of 
194 more than 150 rhizomes of Osmundastrum cinnamomeum have shown that occurrence and

195 configuration of phloem and endodermis are so variable that practically all three of these stele

196 types can occur in just this single extant species; proper recognition of the stele type would then

197 depend on the individual plant and on the position at which it is sectioned (Faull, 1910;

198 Hewitson, 1962; Miller, 1967; Tidwell \& Ash, 1994). In most cases, special modifications have

199 been observed to occur below incipient rhizome bifurcations (see Hewitson, 1962; Miller, 1971).

200 Stem cortex

201 The structure of the stem cortex (Fig. 5) is an important feature for higher-level taxonomic

202 classification in Osmundales. In Guaireaceae, the cortex is composed primarily of parenchyma

203 with interspersed sclerotic nests or secretory ducts, and is not differentiated into distinct layers.

204 In Osmundaceae, by contrast, it is differentiated into an inner, primarily parenchymatous layer

205 and an outer sclerenchymatous layer (Fig. 5). The composition of the outer cortex is usually

206 homogeneous, but has distinct cylinders of particularly thick-walled fibres surrounding the leaf

207 traces in Leptopteris and Todea (e.g., Miller, 1971). The structure of the stem cortex also

208 determines the makeup of the stipe cortex (see there).

\section{Leaf traces}

210 Leaf traces in Osmundales develop from protoxylem poles that appear initially in subexarch to

211 mesarch position in the peripheral metaxylem siphon of the stele (Figs 4, 6). At a specific point

212 in the upward and outward course of the leaf trace through the stem, the protoxylem becomes

213 'exposed' at the adaxial surface of the trace (thereby making the trace endarch), and begins to

214 divide as the trace widens and its curvature increases. Once outside the stem, the trace forms a

215 strongly adaxially curved, endarch, entire vascular bundle with incurved or recurved tips (Figs 6, 
216 7). The number of initial protoxylem poles per leaf trace and the points of exposure and first

217 division of the protoxylem in the stem represent important diagnostic criteria (Fig. 6).

218 Miller (1971) described and illustrated three modes of leaf-trace and gap formation in

219 Osmundaceae, which have been adopted in many comparisons and included in morphological

220 matrices. In reference to earlier descriptions (Kidston \& Gwynne-Vaughan, 1910; Miller, 1967),

221 two of these examples were labelled 'delayed gap' and 'immediate gap', respectively, depending

222 on whether the gap breaks through to the pith upon or after the departure of the trace from the

223 stele; the third example was termed 'Plenasium-type gap', characterized primarily by the fact

224 that each leaf trace is formed from two independent protoxylem poles from two adjacent xylem

225 segments. Tidwell and Ash (1994) illustrated three additional, complex types of leaf-trace

226 formation occurring in Osmundacaulis species, two being termed 'semi-plenasoid' (Tidwell \&

227 Jones, 1987) and one 'plenasoid'; these types are superficially similar to those of Plenasium, but

228 differ in that all originate from just a single protoxylem pole and not from two independent poles

229 as in Plenasium.

230 These aforementioned types, however, should not be considered as fixed categories, but

231 rather regarded as selected examples of the wide range of leaf-trace modes that are now known

232 to occur in osmundalean axes (Figs 4, 6). Again, we propose to use descriptive (point-by-point)

233 rather than generalized categorical - and to a large degree interpretative - terminology to

234 accommodate this structural diversity.

235 Important features for characterizing the development of the leaf trace include (1) the

236 number of protoxylem poles from which a leaf trace is formed; (2) the position in which the

237 protoxylem first appears in the stele; (3) the point at which the protoxylem becomes exposed at

238 the adaxial surface of the trace, i.e., at which the trace becomes endarch; (4) the point at which 
239 the protoxylem undergoes first (and subsequent) divisions; and (5) changes in the overall shape

240 of the leaf trace in its course through the stem. Consequently, we score leaf-trace development in

241 our matrix in a series of eight characters that describe the number and position(s) of protoxylem

242 poles in the stele, upon departure of the trace, in the central part of the cortex, and upon

243 departure from the stem (Fig. 6).

\section{Stipe bases}

245 Stipe bases of all Osmundales contain a single vascular bundle that is strongly curved adaxially,

246 i.e., with the opening directed towards the stem. In Osmundaceae, the adaxial margins of the

247 bundle can be straight or incurved, giving the bundle a characteristic horseshoe-shape in

248 transverse section; in Guaireaceae, the margins of the bundle are typically recurved or

249 constricted, giving the bundle an inverse omega-shape or a flask-shape in transverse section (Fig. $2507)$.

251 The anatomy of the stipe derives from the tissues that the leaf trace passes in its course

252 through the stem. The structure of the stipe cortex thus mirrors that of the stem cortex.

253 Consequently, the stipes of Osmundaceae have an inner parenchymatous groundmass that is

254 surrounded by a robust sclerenchyma cylinder, and these resistant stipe bases form a thick

255 persistent mantle around the stem. Furthermore, the stipes in Osmundaceae typically have a pair

256 of basal stipular wings. The stipes of Guaireaceae, by contrast, are primarily parenchymatous

257 like the stem cortex; presumably owing to the lack of mechanical resistance, they do not form a

258 persistent mantle and are rarely preserved. Based on the occurrence of simple petioles lacking

259 stipular wings in Lunea jonesii, however, it has been suggested that guaireaceaen stipes lack

260 stipular wings in general (Tidwell, 1991). The stipe bases of Itopsidema vancleavii and of the 
261 poorly known Bathypteris rhomboidea bear large, multicellular spines (Daugherty, 1960; see 262 Miller, 1971).

263 Of special importance for the classification of Osmundaceae is the occurrence, distribution 264 and distalward differentiation of sclerenchyma at particular levels and in particular tissue regions 265 of the stipe. Characteristic sclerenchyma configurations can be found in the concavity of the 266 vascular bundle, the inner cortex surrounding the bundle, the sclerenchyma cylinder (i.e., the 267 stipe outer cortex), and the stipular wings (Fig. 7). In the primarily parenchymatous ground-mass 268 of the (inner) cortex and the stipular wings, sclerenchyma may occur in the form of isolated 269 scattered cells (commonly refrerred to as 'fibres') or of larger masses whose positions and shapes 270 may change from the base of the stipe distally (Fig. 7). Typical patterns include, for instance:

271 solid or interrupted bands of sclerenchyma lining the adaxial or the abaxial side of the trace 272 concavity; one central mass or two lateral masses of sclerenchyma inside the trace concavity, or 273 one or several elongate patches of sclerenchyma in the centre of each stipular wing (Fig. 7).

274 Of further importance is the occurrence and development of masses of particularly thick275 walled fibres within the sclerenchymatic outer cortex of the petiole, i.e., in the 'sclerenchyma 276 ring' or 'sclerenchyma cylinder' of the stipe (Fig. 7). In all modern Osmundaceae (genera with 277 extant representatives, i.e., Todea, Leptopteris, Claytosmunda, Osmundastrum, Osmunda, and 278 Plenasium), the composition of this sclerenchyma cylinder is heterogeneous and shows 279 distinctive configurations of patches of thick-walled sclerenchyma cells. Differentiation of the 280 cylinder typically begins with the development of an arch or crescent of thicker-walled cells

281 lining the abaxial periphery of the ring in cross-section. This abaxial arch then begins to 282 differentiate further into characteristic patterns that are diagnostic of particular genera, 283 subgenera, and species (Fig. 7): in extant Todea, Leptopteris, and Plenasium, the arch 
284 differentiates distally into a complete ring of thicker-walled cells at the outer periphery of the

285 sclerenchyma ring; in Osmundastrum, it differentiates into two lateral masses and one abaxial

286 mass; in Claytosmunda, it differentiates into just two lateral masses; and in extant Osmunda, it

287 develops initially into two lateral masses that, further along the stipe, conjoin along the adaxial

288 side of the ring to form an adaxial arch. Additional patterns may occur in other fossil

289 representatives of modern Osmundoideae, although most of the Mesozoic fossil rhizomes of

290 modern Osmundoideae typically have configurations that are similar to those represented in the

291 extant Osmundastrum and Claytosmunda.

292 Roots

293 Roots in all Osmundales contain a single, diarch vascular bundle with two opposite protoxylem

294 poles in exarch position. In a few Permian Osmundaceae (i.e., Chasmatopteris, Palaeosmunda,

295 some Thamnopteris), the root vascular bundles may also (rarely) be triarch (see Gould, 1970). In

296 most cases, the root cortex consists of parenchyma surrounded by a sclerenchymatic sheath. In

297 Osmundaceae, roots generally arise from the stele or laterally from departing leaf traces, whereas

298 they may also arise abaxially from leaf traces further out in the cortex in Guaireaceae. Outside

299 the stem, the roots in many arborescent taxa accumulate to form a dense root mantle (e.g., most

300 Guaireaceae; see, e.g., Tidwell \& Ash, 1994), or may gradually replace softer tissues in the

301 mantle of stipe bases (in Osmundaceae; see, e.g., Miller, 1971). 
302 Material and Methods

\section{A novel morphological character matrix}

304 In order to resolve systematic relationships among extant and fossil Osmundales based on axis

305 anatomy and to aid description and taxonomic assessment of forthcoming material, we

306 developed a novel morphological character matrix (Supplemental Files S1 and S2). The basic

307 organization of this matrix follows that of a previous study (Bomfleur et al., 2015), which in turn

308 was based on that of C.N. Miller's (1971) analyses. Our previous matrix consisted of 34

309 operational units and 33 binary or ternary characters; it was designed specifically for placing

310 extinct members of modern Osmundaceae genera into a phylogenetic reconstruction

311 incorporating molecular data from extant species. The new matrix presented below (129

312 operational units and 45 unweighted binary or ternary characters; Supplemental Files S1 and S2)

313 is, by contrast, designed to better accommodate the morphological disparity in extinct

314 Osmundales as a whole. Its main purpose is to provide a standard framework for the description,

315 identification, and classification of 'natural' taxa, which may provide a more solid basis for

316 reconstructing the evolution of the order. An annotated version of the matrix (NEXUS-

317 formatted) is included in the Supplementary Data Archive (SDA) included in the Supplemental

318 Information linked to this paper.

319 Annotated character list

320 Character 1. Stem core: tracheids: (0) absent; (1) accessory; (2) forming main tissue. 
321 Character 2. Stem-core tracheids (separated and modified from character I.A of Miller, 1971:

322 (0) long (up to ten or more times longer than broad); (1) short (one to three times, rarely up to

323 five times longer than broad).

324 Character 3. Stem core: parenchyma: (0) absent; (1) accessory; (2) forming main tissue.

325 Character 4. Stem core: sclerenchyma: (0) absent; (1) present, scattered; (2) variable, up to 326 entirely sclerified. [character II.B of Miller, 1971 and character 8 of Bomfleur et al., 2015]

327 Character 5. Stele: (0) solid or diffusely heterogeneous; (1) heterogeneous with a distinct 328 peripheral xylem siphon. [Modified from character I.A of Miller, 1971 and from character 4 of 329 Bomfleur et al., 2015]

330 Character 6. Thickness of stelar xylem siphon: $(0)<30$ tracheids thick; $(1)>30$ tracheids thick. 331 [Modified from character II.C of Miller, 1971 and from character 9 of Bomfleur et al., 2015]

332 Character 7. Leaf gaps (i.e., external notches or incisions into the metaxylem siphon above 333 departing leaf traces): (0) absent; (1) shallow (shallower than leaf-trace thickness); (2) prominent 334 (deeper than leaf-trace thickness). [Replaces characters 4 and 5 of Bomfleur et al., 2015]

335 Character 8. Degree of stele perforation: (0) (nearly) imperforate: $\leq 3$ complete perforations; (1) 336 moderately to densely perforated: 4-15 complete perforations, number of complete perforations 337 per mm stele perimeter $(P m m S) 0.11-2.45$; (2) highly perforated: $\geq 16$ complete perforations and $338 P m m S \geq 0.30$. [Modified from character III.R of Miller, 1971; replaces characters 4, 5, and 10 of 339 Bomfleur et al., 2015]

340 This categorisation is based on the results of $k$-median clustering analyses undertaken with 341 Cluster 3.0 (de Hoon et al., 2004; see Bomfleur et al., 2015 for configuration details) and $k=3$ 
342 (see File S1) based on (a) the absolute number of complete perforations and (b) the relative

343 number of complete perforations per mm of stele perimeter $(P m m S)$ expressed in the formula

344

345

346

348

350

351

352

353

354

355

356

360

361

362

363

364

$$
P m m S=\frac{N(C P)_{\max }}{(d(\text { Stele }) * \pi)} \text { (Formula 1) }
$$

in which $N(C P)_{\max }$ is the maximum number of complete perforations in a given transverse section of the stelar xylem cylinder; $d$ (Stele) the stele diameter (see

$$
\text { Supplemental Table S1). }
$$

The $P m m S$ value was included to check for potential cylinder thickness influence on the number of perforations. For instance, xylem cylinders of Guairea have a moderate maximum number of complete perforations (12-18) but very large steles. Consequently, they appear much less perforated than, e.g., Millerocaulis herbstii and Osmunda shimokawaensis with the same maximum number of complete perforations (18), which are much more densely spaced $(P m m S=$ 1.42 compared to $0.11-0.13$ in Guairea). Final values range between entirely imperforate to highly perforate with 75 complete perforations (Plenasium dakotense) and 2.45 perforations per mm stele perimeter (Millerocaulis amarjolensis). Inferred cut-off values of the clusters were $\leq 4$, $5-15$, and $\geq 16$ for complete perforations and $\leq 0.56$ and $\geq 0.6(k=2)$ or $\leq 0.32,0.36-0.95$, and $\geq 0.99(k=3)$, respectively.

Most operational units in the first cluster have no or only few complete perforations and accordingly low $P m m S$ values $(\leq 0.19)$; those were scored as '(nearly) imperforate' (Supplemental Table S1). The two operational units with four complete perforations have much higher PmmS values $(0.64,0.75)$, comparable to values found frequently in operational units with five or more perforations, hence, these were scored as 'moderately perforate'. One of the 35 operational units with $\geq 16$ complete perforations (scored as 'highly perforate') has an extremely 
365 low PmmS value (Guairea braziliensis, 18 complete perforations; PmmS $=0.11$ ), hence this

366 species was scored as 'moderately perforate' by analogy with its congeners with similar PmmS

367 but fewer complete perforations (12-14). Next lowest PmmS values in the group of operational

368 units scored as 'highly perforate' are found in three Osmundacaulis species $(P m m S=0.30-0.32$;

369 value gradually increases in other species of the same genus). The $5-15$ complete perforations in

370 the remainder (49 operational units) can be widely or densely spaced. We categorized these as

371 'moderately to densely perforate'.

372 Character 9. Internal embayments in xylem siphon (indicative of an incipient complete leaf-gap

373 formation): (0) none; (1) fewer than peripheral incisions; (2) as many as or more than peripheral

374 incisions. [This descriptive character records the relative degree to which a complete perforation

375 extends down- and inwards into the stele, resulting in the occurrences of inverse U-shaped

376 transverse sections of (parts of) xylem segments]

377 Character 10. Parenchyma interspersed in stelar xylem, creating 'spongy' structure: (0) absent;

378 (1) present. [New character that was included to recognize the different tissue composition in the

379 steles of Itopsidema, Donwelliacaulis, and Tiania]

380 Character 11. Dissected condition, i.e., with external and internal endodermal layers connecting

381 through leaf gaps: (0) absent or very rare; (1) usually present. [Modified from character II.D of

382 Miller, 1971 and character 7 of Bomfleur et al., 2015]

383 Character 12. Dictyostelic condition, i.e., with external and internal phloem connecting through

384 leaf gaps: (0) absent or very rare; (1) usually present. [Modified from character II.D of Miller,

3851971 and from character 6 of Bomfleur et al., 2015]

386 Character 13. Relative thickness of cortex (RTC): $(0)<1.2 ;(1)[1.2 ; 2.8] ;(2)>2.8$. The relative 387 thickness of the cortex was quantified using Formula 2. As in the case of Character 8, a $k$ - 
388 median clustering with three classes $(k=3)$ was used to define thresholds for each character

389 state.

390

$$
R T C=\frac{d(\text { Stem })_{\max }-d(\text { Stele })_{\max }}{d(\text { Stele })_{\max }} \text { (Formula 2) }
$$
in which $d(\text { Stem })_{\max }$ is the maximum stem diameter; $d(\text { Stele })_{\max }$ the maximum stele diameter.

393 Final values for $R T C$ ranged between 0.14 in Osmundacaulis zululandensis and 13.62 in 394 Bathypteris rhomboidea (Supplemental Table S1).

395 Character 14. Third, entirely parenchymatous inner cortex layer: (0) absent; (1) present. [New 396 character accounting for the distinct third cortex layer in outgroup taxa]

397 Character 15. Composition of the inner cortex (the inner one of two main layers): (0) 398 parenchyma only; (1) parenchyma with scattered sclerenchyma cells; (2) parenchyma with a 399 patch of fibres adaxial to each departing leaf trace. [Character II.G of Miller, 1971]

400 Character 16. Sclerenchymatous outer cortical layer: (0) absent; (1) thinner than

401 parenchymatous layer; (2) thicker than parenchymatous layer. [Modified from characters I.B and 402 II.F of Miller, 1971 and from character 16 of Bomfleur et al., 2015]

403 Character 17. Sclerenchymatous outer cortical layer: (0) homogeneous; (1) heterogeneous with 404 a distinct cylinder of thicker-walled sclereids surrounding each leaf trace. [New character 405 accounting for the heterogeneous composition of the outer cortex in Todea and Leptopteris; see 406 Hewitson, 1962; Chandler, 1965; Miller 1967, 1971; compare character 1243 of Jud et al., 2008]

407 Character 18. Number of initial protoxylem poles per leaf trace: (0) one; (1) two; (2) more than 408 two. [Character 16 of Wang et al., 2014b and character 11 of Bomfleur et al., 2015] 
409 Character 19. Leaf-trace protoxylem initiation in stele: (0) subexarch in peripheral bulge; (1)

410 mesarch. [New character accounting for the different position of protoxylem in the stems of

411 Thamnopteroideae; see Miller, 1971]

412 Character 20. Number of leaf-trace protoxylem strands upon departure from stele: (0) one; (1)

413 two; (2) more than two. [Modified, descriptive coding of characters I.F, II.H, and III.E of Miller, 414 1971]

415 Character 21. Position of leaf-trace protoxylem strands upon departure from stele: (0) lateral;

416 (1) mesarch; (2) endarch. [Modified from character I.D of Miller, 1971]

417 Character 22. Shape of leaf-trace immediately after departure from stele: (0) oblong or slightly 418 curved adaxially; (1) strongly curved adaxially; (2) two individual segments. [New character 419 based on observations by Chandler, 1965 and Miller, 1971]

420 Character 23. Number of leaf-trace protoxylem strands in central part of cortex: (0) one; (1)

421 two; (2) more than two. [Modified, descriptive coding of characters I.F, II.H, and III.E of Miller, $422 \quad 1971]$

423 Character 24. Position of leaf-trace protoxylem strands in central part of cortex: (0) mesarch;

424 (1) endarch. [Expanded from modified character I.D of Miller, 1971]

425 Character 25. Number of leaf-trace protoxylem strands upon departure from stem: (0) one; (1)

426 two; (2) more than two. [Modified, descriptive coding of characters I.F, II.H, and III.E of Miller, 427 1971]

428 Character 26. Shape of stipe bundle immediately after departure from stem: (0) oblong or only 429 slightly curved adaxially; (1) strongly curved adaxially. 
430 Character 27. Lateral tips of stipe bundle immediately after departure from stem: (0) straight or

431 incurved; (1) recurved.

432 Character 28. Sclerenchyma lining stipe bundle abaxially: (0) absent; (1) interrupted; (2)

433 continuous.

434 Character 29. Sclerenchyma in stipe-bundle concavity: (0)absent; (1) free mass; (2) lining band.

435 Character 30. Sclerenchyma in stipe-bundle concavity, special states: (0) solid; (1)

436 interrupted/scattered; (2) bifurcating.

437 Character 31. Appearance of sclerenchyma in stipe-bundle concavity: (0) in stipe only; (1)

438 extending proximally into stem cortex; (2) extending proximally into stele.

439 Character 32. Scattered sclerenchyma in inner cortex of stipe: (0) absent; (1) present.

440 Character 33. Stipe cortex with distinct outer sclerenchyma cylinder: (0) absent; (1) present.

441 Character 34. Sclerenchyma cylinder of stipe base: (0) homogeneous or diffusely

442 heterogeneous; (1) heterogeneous, having a distinct abaxial arch of thick-walled fibres in basal

443 cross-sections.

444 Character 35. Abaxial arch developing distally into a complete ring: (0) absent; (1) present.

445 Character 36. Abaxial arch differentiating distally into two lateral masses: (0) absent; (1)

446 present.

447 Character 37. Abaxial arch (or two lateral masses) differentiating distally into two lateral

448 masses and one abaxial mass: (0) absent; (1) present.

449 Character 38. Two lateral masses developing distally into an adaxial arch: (0) absent; (1)

450 present. 
451 Character 39. Stipular extensions: (0) none; (1) wings; (2) spines.

452 Character 40. Scattered sclerenchyma fibres in stipular wings: (0) absent; (1) present.

453 Character 41. Distinct sclerenchyma masses in stipular wings: (0) absent; (1) one mass in each 454 wing; (2) Two or more masses in each wing.

455 Character 42. Shape or arrangement of distinct sclerenchyma masses in cross-sections of 456 stipular wings: (0) irregular; (1) elongate along lateral extent of stipular wing.

457 Character 43. Point of root emergence: (0) always from stele; (1) from leaf trace upon emission 458 from stele; (2) from leaf trace further out in cortex.

459 Character 44. Number of roots per leaf trace: (0) one, sporadically two; (1) two, sporadically 460 one.

461 Character 45. Predominant orientation of roots in mantle cross-section as an indicator of 462 arborescence: (0) primarily vertical; (1) primarily radial.

464 The more differentiated 'operational units' (typically taxa) are coded into a character matrix, the 465 better-substantiated the inferences will be. In this respect, the increasing use of the genus as the 466 basic category in evolutionary studies is problematic because genera are often arbitrarily 467 circumscribed, non-equivalent concepts that do not exist in reality (Hendricks et al., 2014).

468 Arbitrary blending of the varied morphological information from a pool of species or specimens 469 into a single 'generic-level composite' eliminates potentially informative data from the analysis, 470 just like subjective exclusion of operational units does. The optimal solution would be to use not 471 just species, but specimens as the basic operational units in a morphological character matrix 472 (see, e.g., Upchurch et al., 2004; Tschopp et al., 2015). However, an all-specimen-level analysis 
473 of fossil Osmundales is impossible at present because species descriptions that are based on more

474 than one specimen usually do not list specimen data separately but summarize all morphological

475 information available in the form of ranges of values, ratios and dimensions.

476 Nevertheless, we aim to include as much in-group information in our analysis as possible.

477 Therefore, the matrix includes not just all currently accepted species, but also additional

478 operational units that contain independently coded information either from synonymous species

479 or from separate, individually documented fossil records (Supplemental Table S1; Supplemental

480 Files S1 and S2). As a result, (1) Plenasium dowkeri (Carruth.) Bomfleur, G.Grimm \&

481 McLoughlin sensu Miller is separated into two operational units: Plenasium dowkeri (Carruth.)

482 Bomfleur, G.Grimm \& McLoughlin sensu Chandler (see Chandler, 1965) and Plenasium

483 chandleri (Arnold) Bomfleur, G.Grimm \& McLoughlin (see Arnold, 1952); (2) Guairea carnieri

484 (J.Schust.) R.Herbst is separated into two operational units Guairea carnieri (J.Schust.) R.Herbst

485 'sensu Miller' (see Schuster, 1911; Miller, 1971) and its junior synonym Osmundacaulis

486 braziliensis (H.N.Andrews) C.N.Mill. (see Andrews, 1950; Miller, 1971); (3) Millerocaulis

487 dunlopii (Kidst. \& Gwynne-Vaughan) Tidwell is separated into Millerocaulis dunlopii (Kidst. \& 488 Gwynne-Vaughan) Tidwell 'sensu Kidston \& Gwynne-Vaughan (1907)’ and its junior synonym

489 Osmundites aucklandicus P.Marshall (see Marshall, 1926); (4) Osmundacaulis hoskingii

490 R.E.Gould is separated into Osmundacaulis hoskingii var. hoskingii R.E.Gould and O. hoskingii

491 var. tabulatus R.E.Gould (see Gould, 1973); (5) Millerocaulis australis (E.I.Vera) E.I.Vera is

492 separated into two operational units, one being based on the original type specimen (Vera, 2007)

493 and the other being based on the later report of an additional specimen with slightly different

494 features (Vera, 2010); (6) Osmundastrum precinnamomeum (C.N.Mill.) Bomfleur, G.Grimm \&

495 McLoughlin, which some authors consider to be a junior synonym of $O$. cinnamomeum (L.) 
496 C.Presl (see Serbet \& Rothwell, 1999; Matsumoto \& Nishida, 2003), is coded as a separate

497 operational unit; and (7) Osmundastrum cinnamomeum is further separated into four operational

498 units based on information from extant material (see Miller, 1971) and from three individual

499 fossil occurrences of this species from the Neogene of Japan (Matsumoto \& Nishida, 2003) and

500 from the Cretaceous and Neogene of North America (Serbet \& Rothwell, 1999; Miller, 1967).

501 The selection of extant species is adopted from Miller (1971); the coding of these species is

502 based on Miller's (1971) character lists but has, whenever possible, been supplemented with

503 additional information from earlier literature on the anatomical structure of Osmundaceae (Faull,

504 1901; Seward \& Ford, 1903; Bower, 1911, 1926; Gwynne-Vaughan, 1911, 1914; Hewitson,

505 1962; Miller, 1967). Sources for revised data are provided in the form of comments either in the

506 final matrix (Supplemental Files S1 and S2) or in the spreadsheet listing morphological features

507 (Supplemental Table S1).

508 Outgroup operational units have been selected based on earlier suggestions that

509 Grammatopteris and Rastropteris belong to a group of filicalean ferns closely allied to

510 Osmundales (see Sahni, 1932; Miller, 1971; Galtier et al., 2001; Rößler \& Galtier, 2002). In

511 contrast to the most recent phylogenetic analysis (Wang et al., 2014b), we retain Grammatopteris

512 as an outgroup operational unit because it does not show sufficient diagnostic characteristics to

513 warrant assignment to Osmundales. Furthermore, we included the fossil Grammatocaulis

514 donponii as an additional outgroup operational unit because of its close similarity to

515 Grammatopteris (Tidwell \& Rozefelds, 1990).

516 In order to mitigate noise and poor definition of pairwise distances from uninformative

517 operational units with too much missing data, we excluded those operational units with more

518 than $60 \%$ missing characters (an arbitrary cut-off value) from the analyses. This applies to 
519 Anomorrhoea fischeri, Claytosmunda nathorstii, Osmunda kidstonii, Osmundacaulis janae, and

520 Todea papuana (Supplemental File S3). The status of Anomorrhoea fischeri is problematic

521 because too many diagnostic features essential for systematic classification are missing (see

522 Miller, 1971). Claytosmunda nathorstii, Osmunda kidstonii, and Osmundacaulis janae are only

523 known from petiole sections (see Miller, 1971; Tidwell \& Pigg, 1993) that, however, permit

524 unambiguous generic assignment. No detailed information has been published on the anatomical

525 structure of Todea papuana; the species remains in our matrix solely because it yielded

526 molecular information used in an earlier version of the matrix (Bomfleur et al., 2015; Grimm et

527 al., 2015).

\section{Data acquisition and character coding}

529 The character coding for the individual operational units is based on data from published

530 literature. Wherever possible, the coding was compiled on the basis of the original protologue of

531 the particular taxon. Data adopted from diagnoses and descriptions were critically checked with

532 information provided by accompanying illustrations. In case information was lacking from the

533 original text, coding of the operational unit was completed as far as possible using accompanying

534 illustrations or additional information from later references; in cases of conflict between figured

535 material and text descriptions, data were corrected according to the illustrations. Common

536 problems that we encountered concern, for instance, erroneous dimensions of stem features

537 resulting from the inconsistent use of the terms 'stele', 'stem' (i.e., stele plus cortex), and 'trunk'

538 or 'rhizome' (i.e., stele plus cortex plus mantle). Another source of error is the inconsistency in

539 counting stelar xylem segments, depending on whether they are counted as separate already

540 when they are deeply divided or only when they are entirely isolated from another ('Hewitson's

541 method'). In any case, corrected data are indicated as such in the form of annotations either in 
542 the spreadsheet compilation of morphological features (Supplemental Table S1) or in the final

543 matrix file (Supplemental Files S1 and S2).

\section{Phylogenetic analysis}

\section{Use of phylogenetic networks}

546 Classification of fossils should be based on morphology rather than theoretical concepts. The

547 study of evolutionary processes, however, requires phylogenetically meaningful (as opposed to

548 merely phenetic) 'natural' taxa, and the definition of such 'natural' groups requires an implicit

549 phylogenetic framework via the recognition of evolutionary lineages of common ancestry

550 (Darwin, 1859; Haeckel, 1866; Simpson, 1945; Fig. 8A). In the absence of extant representatives

551 of most Osmundales lineages, and hence, molecular data for these groups, the framework can

552 only be based on morphological traits - characters of uncertain evolutionary relevance (e.g.,

553 Scotland et al., 2003; Wiens, 2004) but with substantial impact on phylogenetic inferences (e.g.,

554 Hillis \& Wiens, 2000; Wiens, 2004; Müller \& Reisz, 2006; Cobbett et al., 2007).

555 Signals from morphological matrices are generally complex, especially if fossil

556 (presumably primitive) and modern (presumably derived) taxa from different time periods are

557 pooled (e.g., Cobbett et al., 2007; Denk \& Grimm, 2009). With more than 100 operational units

558 but fewer than 50 characters, our matrix dimensions are far from optimal. We refrained from

559 filtering homoplastic characters and those that are generally variable within potential lineages

560 because even those might still prove useful for discrimination at and above species level.

561 Phylogenetically unsorted, homoplastic signals (incompatible with the true tree) can outcompete

562 phylogenetically informative (compatible with the true tree) signals, eventually resulting in 
563 erroneous tree inferences, especially if parsimony is used as the optimality criterion (Scotland \&

564 Steel, 2015). Incongruent signals, i.e., in which different sets of characters prefer contrasting

565 topologies, are common and pose an additional problem for phylogenetic inference. On the other

566 hand, taxa sharing a common origin are typically more similar to each other than those not

567 sharing a common origin (e.g., Felsenstein, 2004).

568 Altogether, we tried to keep the phylogenetic analyses as simple and straightforward as

569 possible: we used a matrix of unsorted and unweighted characters to infer neighbour-net splits

570 graphs (Bryant \& Moulton, 2002, 2004) based on simple (Hamming) pairwise distances.

571 Neighbour nets are designed to better handle incompatible signals, and are more sensitive with

572 respect to actual ancestor-descendant relationships than are dichotomous trees (Spencer et al.,

573 2004; Denk \& Grimm, 2009). The distance between two tips in a Neighbour net reflects the

574 actual distance value, which is not necessarily the case in dichotomous trees (Bryant \& Moulton,

575 2004; Huson \& Bryant, 2006).

576 Analytical procedure

577 Neighbour nets were inferred from pairwise Hamming (mean) distance matrices, and were

578 visualized using SplitsTree v. 4.13 (Huson \& Bryant, 2006). Distances were computed with

579 PAUP* v. 4 b10 (Swofford, 2002) using the default settings on the complete set of operational

580 units and on selected taxon subsets (lineages; see Supplemental File S3 for details). As pairwise

581 distances become increasingly unrepresentative with the proportion of missing data, operational

582 units with more than 60\% undefined characters (Anomorrhoea fischeri, Claytosmunda nathorstii,

583 Osmunda kidstonii, Osmundacaulis janae, Todea papuana) were excluded from the analyses.For

584 each set analysed, we further excluded all invariant ('constant') characters before calculating the

585 pairwise distances so that the resulting distance matrices and neighbour-net splits graphs are 
586 based only on those characters that are variable (and thus effective) within the focal group;

587 hence, a 0.1 distance between two operational units indicates that they differ in $10 \%$ of those

588 characters that are variable within the selected set of operational units. This procedure allowed us

589 to focus on particular aspects of morphological diversity in osmundalean lineages. Furthermore,

590 it helped interpret bootstrap support values as approximations (in the ideal case) of the

591 proportion of characters supporting a given phylogenetic split (i.e. a clade in a rooted

592 phylogenetic tree) (Supplemental File S3).

593 The distance quality ('tree-likeness') of the signals from the entire matrix and from taxon

594 subsets was estimated using the mean delta value (MDV) and the range of individual delta values

595 (IDV) within (Holland et al., 2002; Auch et al., 2006; Göker \& Grimm, 2008; Supplemental File

596 S3). Delta values summarize the weight proportion between the two possible, competing edge

597 bundles for quartets of operational units ('four-taxon subsets'), either for the entire matrix (in

598 case of the MDV) or for all quartets including a selected recombinant operational unit (in case of

599 IDV) (see Holland et al., 2002, for the formula). A delta value $\sim 0$ indicates high distance quality

600 and thus a highly treelike signal; a delta value $\sim 1$ indicates poor distance quality with highly

601 ambiguous signals, with the resulting tree approaching the form of a star with equally long

602 terminal branches for all taxa.

603 To estimate robustness of support for inferred (or hypothesized) relationships, we used

604 non-parametric bootstrapping (BS; Felsenstein, 1985) under three optimality criteria: maximum

605 likelihood (ML), least-square (LS), and parsimony. For ML-BS, we used the fast bootstrapping

606 implemented in RAxML v. 8.2 (Stamatakis et al., 2008; Stamatakis, 2014; option -x); for ML

607 optimisation, we used Lewis' (2001) Mk substitution model for categorical characters, allowing

608 for between-site variation modelled as a Gamma distribution. For LS-BS, we used the BioNJ 
609 modification (Gascuel, 1997) of the neighbour-joining (NJ) algorithm (Saitou \& Nei, 1987)

610 implemented in PAUP* (Search=NJ/ BioNJ). BS under parsimony was performed using PAUP*

611 following Müller (2005): the 'MulTrees' option was deactivated and the heuristic search was set

612 to a single tree per BS replicate, which was optimized using the default TBR (tree-bisection-and-

613 reconnection) branch swapping (Search=Heuristic, NRep $=1$, AddSeq=Furthest). BS supports

614 (split frequencies) are based on 10,000 pseudoreplicates for ML, LS/NJ, and parsimony. The

615 ambiguous signals in the BS pseudoreplicate samples can be studied using bootstrap consensus

616 networks (Schliep et al., 2017; 'bipartition networks', Grimm et al., 2016), a special form of

617 consensus network (Holland \& Moulton, 2003) in which the edge lengths are proportional to the

618 frequency of the corresponding phylogenetic split (taxon bipartition) in the underlying BS

619 pseudoreplicate sample (option 'count' in SplitsTree). For clarity, all splits with a frequency of $<$

$62010 \%$ were filtered.

621 All (raw) files for analyses (input, batch and results files) are provided in the Supplemental Data

622 Archive.

623 Paraphyletic groups as valid taxonomic units

624 Classification was historically based on form regardless of evolutionary relationships (see Fig.

625 8B). By contrast, cladistics-based systematics - today the prevalent school of thought in

626 systematic biology - accepts as valid taxonomic units only holophyletic groups (i.e.,

627 'monophyletic' in the sense of Hennig, 1950 and not of Haeckel, 1866; see Ashlock, 1971; Mayr

628 \& Bock, 2002; Hörandl, 2006, 2007). Whether a group is holophyletic is either observed in the

629 form of at least one unique and derived ('synapomorphic') trait shared by all its members

630 (Hennig, 1950) or inferred from a cladogram or phylogram, in which holophyly — the inclusive

631 common ancestry of a group of taxa - is defined by the fact that two or more taxa comprise a 
632 single complete subtree (clade) in a rooted phylogenetic tree (Farris, 1983). In the case of

633 morphological matrices, the cladogram used as the basis for classification is usually inferred

634 using parsimony as the optimality criterion, presumably for no other reason than to be consistent

635 with traditional assertions by early cladists (Felsenstein, 2001, p. 466).

636 Albeit theoretically appealing owing to its simplicity and its sense of objectivity and

637 reproducibility, the ideal of a classification that accepts only holophyletic groups has severe

638 disadvantages in practice (e.g., Mayr \& Bock, 2002; Hörandl 2006, 2007; Van Wyk, 2007; see

639 Figs $8 \mathrm{C}-\mathrm{E}$ ). Just a single newly scored trait in a morphological matrix may change a clade in a

640 phylogenetic tree into a grade or vice versa, thwarting the aim of nomenclatural and taxonomic

641 stability (compare the results of Rothwell et al., 2009 with those of Crepet \& Stevenson, 2010);

642 imbalanced scoring of traits, homoplasy, and long-branch attraction can result in the recovery of

643 artificial clades that are polyphyletic in reality (e.g., Scotland \& Steel, 2015); new evidence may

644 reveal that a synapomorphy is a symplesiomorphy or even a convergently evolved trait; and

645 insufficient numbers of derived diagnostic features in ancestral members of an evolutionary

646 lineage may obstruct the recovery of a clade, which also applies to extinct sister lineages of

647 extant groups. Conversely, extinct groups might have independently evolved derived features

648 that occur today only in a single surviving lineage; hence, aut- or synapomorphies of modern

649 taxa may be convergences over time (Fig. 8A). Thus, comprehensive morphological matrices

650 that include extinct and extant organisms provide a combination of signals that is generally non-

651 treelike, i.e, that is too complex to enable the inference of a single phylogenetic tree as an

652 accurate representation of the systematic relationships of its taxa. Branches instead become

653 unstable, support is generally low, and topologies are drastically affected by character coding

654 (compare, e.g., comprehensive morphology-based seed-plant phylogenies obtained by Hilton and 
655 Bateman, 2006; Friis et al., 2007; Rothwell et al., 2009; and Crepet \& Stevenson, 2010). These

656 problems render any strict cladistic-phylogenetic classification inherently unstable in the case of

657 fossil plants or plant groups with fossil and extant members. Even if the evolutionary pathways

658 were known in detail (Fig. 8A), a cladistic classification, applied consistently above the species

659 level, remains problematic. If each genus would be inclusive for extinct and extant members of a

660 subtree that can be diagnosed by one or a few unique characters, or characteristically conserved

661 suites of characters, some fossils (such as ancestors of more than a single extant genus) would

662 need to remain unnamed (Fig. 8C). Alternatively, all species/specimens including the earliest

663 representative of the lineage would need to be included in one large and morphologically

664 disparate genus, to the effect that phylogenetically unambiguously resolved extant genera would

665 need to be renamed and 'down-graded' to subgenera (Fig. 8D). As a consequence, many

666 classifications of lineages with fossil and extant representatives are chimaeras (Fig. 8E) with the

667 modern taxa classified according to molecular-data-derived (i.e., assumedly holophyletic) clades

668 and the remaining fossil specimens being assigned variably to modern lineages or to more- or

669 less artificial 'form-genera', 'morphotaxa', or 'fossil taxa', for which holophyly need not be

670 established.

671 An improtant step towards resolving these problems may be to accept (potentially)

672 paraphyletic taxa as valid taxonomic units following the concept of 'evolutionary classification'

673 (see, e.g., Mayr \& Bock, 2002; Hörandl, 2006; Van Wyk, 2007: Fig. 8F). For instance, following

674 detailed comparative analysis, it should be valid to assign an ancestor of a group of extant genera

675 to the paraphyletic-per-definition stem genus of these genera if it shows the relevant (lack of)

676 diagnostic characters. Paraphyletic or not, all taxa in our systematic concept are considered

677 natural, monophyletic taxa that share a single common origin (monophyly in the original 
678 Haeckelian sense) and that correspond to evolutionary lineages — ancestral and modern ones-

679 within Osmundales.

680

681 The degree of taxonomic resolution and the number of ranks applied below the rank of order 682 683 684 685 686 687 688

\section{Taxonomic resolution}

vary in our classification depending on the degree of detail to which one taxon can be discriminated from others (see Supplemental Figure S1). Highest taxonomic resolution with up to six ranks (Family, Subfamily, Tribe, Subtribe, Genus, and Subgenus) is achieved only for modern members of Osmundaceae, i.e., those genera with (also) extant species. Extinct, but comparatively well-known lineages are moderately well-resolved in three or four ranks.

Naturally, the most poorly resolved taxa with only one or two ranks resolved are those with uncertain affinities, such as Shuichengella, Osmundacaulis, or Bathypteris.

\section{Nomenclatural remarks}

The electronic version of this article in Portable Document Format (PDF) will represent a published work according to the International Code of Nomenclature for algae, fungi, and plants (ICN), and hence the new names contained in the electronic version are effectively published under that Code from the electronic edition alone. In addition, new names contained in this work which have been issued with identifiers by IPNI will eventually be made available to the Global Names Index. The IPNI LSIDs can be resolved and the associated information viewed through any standard web browser by appending the LSID contained in this publication to the prefix "http://ipni.org/". The online version of this work is archived and available from the following digital repositories: PeerJ, PubMed Central, and CLOCKSS. 


\section{Results and discussion}

\section{Numerical phylogenetic framework}

701 The all-inclusive matrix (S00, all Osmundales + outgroup) provides partly incompatible signals

702 accompanied by substantial intertaxonomic diversity. The maximum pairwise distance found in

703 the Osmundales matrix is 0.81 ; the matrix Delta Value (mDV) is relatively high with 0.38

704 (Supplemental File S3), but is within the range expected for morphological matrices including

705 mainly fossil taxa (GWG, pers. obs.; Supplemental Table S2; see Göker \& Grimm, 2008). In

706 general, a tree derived from a matrix with a mDV $>0.2$ (Supplemental Table S2) can be assumed

707 to represent the signal in the underlying dataset only inadequately, occasionally including clades

708 that are incompatible with molecular data (e.g. Denk \& Grimm, 2005; Denk et al., 2005; Manos

709 et al., 2007; Friis et al. 2009, see also Sareela et al. 2009). In this most comprehensive all-taxa

710 matrix (matrix S00), signals from all operational units are more or less ambiguous; individual

711 Delta Values (iDV) range between 0.31 (Osmundacaulis skidegatensis) and 0.43 (Millerocaulis

712 tuhajkulensis), and the iDVs are largely decoupled from the proportion of missing data

713 (Supplemental File S3). The resulting neighbour-nets reflect the non-treelikeness of the signal in

714 showing pronounced box-like structures and in having generally low bootstrap (BS) support for

715 all known potential and alternative relationships (Supplemental File S3). Our matrix has been

716 optimized for taxonomic assessment. Thus, it includes many homoplastic traits and few generally

717 sorted (informative) individual characters, i.e. characters compatible with splits reflecting

718 potential phylogenetic lineages. Bootstrapping of such matrices produces many pseudoreplicate

719 matrices in which the few sorted, phylogenetically informative characters become replaced by 
720 uninformative ones that provide only diffuse signals. Nevertheless, the BS supports reflect a

721 consistent signal for certain relationships. Overall, the matrix signal is most decisive when using

$722 \mathrm{ML}$ or LS/NJ, whereas the overall support is lowest under parsimony. Apart from this, there are

723 very few apparent conflicts between the different optimization criteria. The diffusion effect from

724 homoplastic signals is mitigated when the analysis is narrowed to a particular taxon subset

725 (Supplemental File S3); for example, support for a clade including all modern Osmundastrum

726 rhizomes, including Cretaceous and younger fossils of $O$. cinnamomeum, is overall low in the

727 all-inclusive matrix $\left(\mathrm{BS}_{\mathrm{ML} / \mathrm{NJ} / \mathrm{MP}}=25 / 30 / 10\right)$, but increases to $\mathrm{BS}_{\mathrm{ML} / \mathrm{NJ} / \mathrm{MP}}=56 / 65 / 18$ for the least-

728 inclusive matrix (Osmundinae) including members of this lineage (Supplemental File S3).

729 The high amount of incompatible signals limits the utility of our matrix for inferring

730 explicit trees as phylogenetic scenarios, but it can to some degree be accommodated using

731 neighbour- nets instead. Taxa that belong to the same (putative) phylogenetic lineage (detailed

732 below), defined by notably similar character suites and sharing traits that are not or rarely found

733 outside the (putative) lineage, are typically grouped in the neighbour nets. The lineage-

734 corresponding edges are usually equivalent to the best-supported alternative(s) found in the BS

735 pseudoreplicates. Furthermore, by adding a new taxon to the matrix (or one of the taxon subsets),

736 its systematic affinities can be readily established (see example provided in Appendix D).

\section{Revised and annotated classification}

738 There is general agreement that Osmundales is holophyletic (see, e.g., Yatabe et al., 1999; Smith

739 et al., 2006; Schuettpelz \& Pryer, 2007; PPG I, 2016; Testo \& Sundue, 2016). Our subdivision of

740 Osmundales into two main families_-Osmundaceae and Guaireaceae — follows most previous

741 studies since Guairea and Guaireaceae were established (Herbst, 1981; see, e.g., Tidwell \& Ash, 
742 1994; Tian et al., 2008; Supplemental Figure S1). Those Guaireaceae taxa that possess perforated

743 (dissected) siphonosteles or dictyosteles (Guairea, Lunea, and Zhongmingella) are assigned to

744 subfamily Guaireoideae, whereas those that possess gapless steles that are composed of a spongy

745 mix of xylem and parenchyma are assigned to a new subfamily, Itopsidemoideae subfam. nov.

746 Osmundacaulis is included in Osmundaceae (see Tidwell \& Ash, 1994) instead of Guaireaceae

747 (see Wang et al., 2014b) because of the occurrence of a two-layered cortex, the C-shaped stipe

748 bundles with incurved tips, and the presence of stipular wings. Also Shuichengella is assigned to

749 Osmundaceae due to its similarly two-layered cortex. Owing to the peculiar cortex organisation

750 with a much thinner sclerenchymatic outer layer and to the otherwise unclear relationships to the

751 remaining taxa in Osmundaceae, we refrain from subfamily assignment of Osmundacaulis and

752 Shuichengella at present. Apart from the poorly known Bathypteris, whose position within

753 Osmundaceae remains uncertain, all other remaining taxa in Osmundaceae are resolved in two

754 subfamilies. Our analyses support Thamnopteroideae as a clearly delimitable subfamily (Miller,

755 1971; Tidwell \& Ash, 1994; see Supplemental Figure S1). Furthermore, Zalesskya,

756 Iegosigopteris, and Petcheropteris are so similar to Thamnopteris (see Zalessky, 1935; Miller,

757 1971) that we consider them synonymous. The remaining Osmundaceae genera, whose stem

758 centre is primarily parenchymatic and whose xylem siphon shows conspicuous leaf gaps, are

759 assigned to subfamily Osmundoideae in accordance with previous studies (see also Miller, 1971;

760 Tidwell \& Ash, 1994; Tian et al., 2008). Extinct genera of Osmundoideae include Palaeosmunda

761 (perhaps including 'Millerocaulis' stipabonettiorum) and Millerocaulis, which is characterized

762 by a plesiomorphic character suite including a homogeneous petiolar sclerenchyma ring without

763 distinct fibre patches. The differentiation of this petiolar sclerenchyma ring into distinct arches

764 and patches of thick-walled fibres is here considered diagnostic for the tribe Osmundeae, which 
765 comprises all six Osmundaceae genera with extant representatives (see PPG I, 2016): Todea and

766 Leptopteris in subtribe Todeinae and Claytosmunda, Osmundastrum, Osmunda, and Plenasium

767 in subtribe Osmundinae. One major taxonomic novelty resulting from our analysis is that

768 Aurealcaulis, whose systematic position has hitherto remained enigmatic (Tidwell \& Parker,

769 1987; Tidwell \& Medlyn, 1991; Tidwell \& Pigg, 1993; Tidwell \& Ash, 1994; Tian et al., 2008;

770 Wang et al., 2014b), is recognized as an extinct subgenus of Plenasium. In addition, several

771 fossil species that were previously included in Millerocaulis or Ashicaulis are recognized as

772 extinct species of subtribe Osmundinae (congruent with the former Osmunda sensu lato), most of

773 which belonging to Claytosmunda and some to Osmundastrum. 'Osmundacaulis' estipularis

774 from the Cretaceous of India (Sharma et al., 1979) is assigned to subtribe Todeinae, and may

775 represent a previously unrecognized fossil member of Leptopteris.

776 Detailed discussion and explanations of our classification are given below in the comments

777 section for the particular taxa.

778 Nomenclatural novelties. Our analysis warrants the following taxonomic changes for members

779 of fossil Osmundales as presently understood: (1) institution of the new subfamily

780 Itopsidemoideae (Guaireaceae) subfam. nov. to contain Itopsidema vancleaveii Daugherty,

781 Donwelliacaulis chlouberii S.R.Ash, and Tiania yunnanense (Bao-Lin Tian \& Jiang-Lin Chang

782 ex Shi-Jun Wang, J.Hilton, Galtier et al.) Shi-Jun Wang, J.Hilton, Galtier et al.; (2) institution of

783 two new subtribes within tribus Osmundeae, i.e., Todeinae subtribe. nov. and Osmundinae

784 subtribe. nov.; (3) synonymy of Zalesskya Kidst. \& Gwynne-Vaughan, Petcheropteris Zalessky,

785 and Iegosigopteris Zalessky with Thamnopteris Brongn. with the resulting new combinations: $T$.

786 diploxylon (Kidst. \& Gwynne-Vaughan) comb. nov., T. gracilis (Eichw.) comb. nov., T. javorskii

787 (Zalessky) comb. nov., T. splendida (Zalessky) comb. nov., T. uralica (Zalessky) comb. nov.; (4) 
788 recognition of a new species of Millerocaulis that was previously assigned to Osmundites, i.e.,

789 M. tuhajkulensis (Gorskii ex Pryn.) comb. nov.; (5) several new combinations in Osmundeae

790 ('modern' Osmundoideae) of species that were previously assigned to Ashicaulis and

791 Millerocaulis, including Claytosmunda beardmorensis (J.M.Schopf) comb. nov., C. chengii

792 nom. nov. (replacement name for a new combination based on Ashicaulis claytoniites

793 Y.M.Cheng), C. johnstonii (Tidwell, Munzing \& M.R.Banks) comb. nov., C. liaoningensis (Wu

794 Zhang \& Shao-Lin Zheng) comb. nov., C. plumites (N.Tian \& Y.D.Wang) comb. nov., $C$.

795 preosmunda (Y.M.Cheng, Yu F.Wang \& C.S.Li) comb. nov., C. sinica (Y.M.Cheng \& C.S.Li)

796 comb. nov., C. tekelili (E.I.Vera) comb. nov., C. wangii (N.Tian \& Y.D.Wang) comb. nov.,

797 Claytosmunda embreei (Stockey \& S.Y.Sm.) comb. nov., Osmundastrum indentatum (R.S.Hill,

798 S.M.Forsyth \& F.Green) comb. nov., and O. kidstonii (Stopes) comb. nov.; (6) new combinations

799 in Osmundinae resulting merely from the recent elevation of former subgenera of Osmunda to

800 separate genera (PPG I, 2016), i.e., Osmundastrum pulchellum (Bomfleur, G.Grimm \&

801 McLoughlin) comb. nov., Plenasium arnoldii (C.N.Mill.) comb. nov., Plenasium chandleri

802 (Arnold) comb. nov., and Plenasium dowkeri (Carruth.) comb. nov.; and (7) recognition of

803 Aurealcaulis as a subgenus of Plenasium with the resulting new species combinations, $P$.

804 bransonii (Tidwell \& Medlyn) comb. nov., P. burgii (Tidwell \& J.E.Skog) comb. nov., P. crossii

805 (Tidwell \& L.R.Parker) comb. nov., P. dakotense (Tidwell \& J.E.Skog) comb. nov., P. moorei

806 (Tidwell \& Medlyn) comb. nov., and P. nebraskense (Tidwell \& J.E.Skog) comb. nov. Formal

807 taxonomic treatment of these nomenclatural novelties is provided in Appendix A.

808 Note on orthography of taxon names. Several taxon names contained orthographical or

809 typographical errors that were corrected according to Articles 60 and 62 of the International

810 Code of Nomenclature for Algae, Fungi, and Plants (Melbourne Code, 2011). Corrected errors 
811 include, e.g., terminations of adjectival epithets not in accordance with the gender of the genus

812 (e.g., Millerocaulis indicus replacing Millerocaulis indica; see Articles 23.5 and 32.2 of the

813 Melbourne Code, 2012); terminations of honorific substantival epithets not in accordance with

814 the sex or number of the person(s) honoured, e.g., lutziae replacing lutzii (in honour of Dr Alicia

815 M. Lutz; see Note 4 on Art. 60 of the Melbourne Code, 2012) or stipabonettiorum replacing

816 stipabonettii (in honour or Drs Stipanicic and Bonetti; see Article 60.12 of the Melbourne Code,

817 2012); or formation of regular compounds not in accordance with classical usage, e.g.,

818 bromeliifolium replacing bromeliaefolium (see Recommendation 60G of the Melbourne Code,

819 2012).

820 General remarks. In the following treatment, the diagnostic axis characters accumulate with

821 increasing resolution of taxonomic rank, i.e., features considered diagnostic of the family are

822 included again also in the diagnosis for the subfamily, and those are together again repeated in

823 the diagnosis of the genus, and so forth. We follow this practice to account for parallelism owing

824 to potentially homoplastic but, nonetheless, informative morphological features: individual

825 features or feature combinations diagnostic of a taxon at a given rank within a given target group

826 may independently also be diagnostic of another distantly related taxon in another target group.

827 Following Miller (1971), we set those features of a diagnosis in italic font whose combination

828 serves best to differentiate this particular taxon from any other taxon at the same rank in the

829 same target group (rank-specific discriminating characters within the target group). By doing so,

830 potentially homoplastic, but nonetheless informative features (e.g., high degree of stele

831 perforation) can serve as differentiating diagnostic characters within a target group of closely

832 related taxa, even though these features may occur independently also within a more distantly

833 related group. 


\section{Order Osmundales Link, 1833}

835 (Figure 9)

836 Diagnostic axis characters. Stems radially symmetrical. Stele with a more or less modified,

837 distinct peripheral metaxylem siphon, with protoxylem initially mesarch or subexarch.

838 Phyllotaxis a tight spiral. Vascular bundle in the stipe base entire, strongly curved adaxially (e.g.,

839 C-, omega-, or horseshoe-shaped), with endarch protoxylem.

840 Status. Holophyletic, extant (relictual) with fossil representatives.

841 Known geochronologic range. Late Permian to present.

842 Comments. The holophyly of all Osmundales, extant and extinct, is universally accepted (see,

843 e.g., Yatabe et al., 1999; Smith et al., 2006; Schuettpelz \& Pryer, 2007). For the family and

844 subfamily subdivision indicated in Figure 9 see relevant descriptions and remarks below.

\section{$8451(\dagger)$ Family Guaireaceae R.Herbst, 1981}

846 (Figure 10)

847 Diagnostic axis characters. Stem and stipe cortex primarily parenchymatous and not

848 differentiated into distinct layers; where known, stipes lacking stipular wings and stipe bundle

849 with recurved tips (i.e., more or less omega-shaped); roots commonly arising from abaxial side

850 of leaf trace within the stem cortex.

851 Status. Putatively holophyletic, extinct.

852 Known geochronologic range. Late Permian to Early Jurassic.

853 Comments. Our subdivision of Osmundales into two main families-Osmundaceae and

854 Guaireaceae-follows most previous studies since Guairea and Guaireaceae were established 855 (Herbst, 1981; see, e.g., Tidwell \& Ash, 1994). The main difference from the most recent 
856 proposed classification (Wang et al., 2014b) is that we exclude Osmundacaulis and

857 Shuichengella from Guaireaceae and re-assign them to Osmundaceae. The corresponding clade

858 in that study is most likely a long-branch artefact. The neighbour net illustrates the

859 morphological disparity within the earliest (Permian) Guaireaceae, but also highlights the

860 relative scarcity of data for members of the family. In the all-inclusive data set, neither family

861 received measurable support $\left(\mathrm{BS}_{\mathrm{ML} / \mathrm{NJ} / \mathrm{MP}}<10\right)$, nor the alternative proposed by Wang et al.

862 (2014) of a family Guaireaceae including Osmundacaulis. Nonetheless, the character suites

863 found in the earliest Guiareaceae and Osmundaceae indicate that they represent potential sister

864 lineages within the Osmundales and that neither one evolved from the other. The position of the

865 Guaireaceae root is undetermined. By analogy with Osmundaceae, Itopsidemoideae may be

866 basal within Guaireaceae considering the imperforate steles of all its members.

$8671.1(\dagger)$ Subfamily Guaireoideae Z.M.Li, 1993

868 Diagnostic axis characters. Stele perforated; stem and stipe cortex primarily parenchymatous

869 and not differentiated into distinct layers; where known, stipes lacking stipular wings and stipe

870 bundle with strongly recurved tips; roots commonly arising from abaxial side of leaf trace within

871 the stem cortex.

872 Status. Possibly holophyletic, extinct.

873 Known geochronologic range. Late Permian to Early Jurassic.

874 Comments. We recognize those Guaireaceae taxa that possess perforated (dissected)

875 siphonosteles or dictyosteles (Guairea, Lunea, and Zhongmingella) as being sufficiently similar

876 to each other and sufficiently distinct from other Guaireaceae (Fig. 9) that we assign them to one

877 subfamily: Guaireoideae. Although (highly) perforated steles also evolved independently in other 
878 Osmundales (in particular, Osmundacaulis; as reflected by $\mathrm{BS}_{\mathrm{ML} / \mathrm{NJ}} \geq 20$ for an artificial

879 Guairea + Osmundacaulis clade using the all-inclusive matrix), they are typically restricted to 880 distinct sublineages with a probable inclusive common origin. The split between Guaireoideae 881 and Itopsidemoideae is well supported $\left(\mathrm{BS}_{\mathrm{ML} / \mathrm{NJ} / \mathrm{MP}} \geq 70\right)$ if the taxon set is restricted to only 882 Guaireacae (Fig. 10).

\section{$1.1 .1(\dagger)$ Genus Guairea R.Herbst, 1981}

Diagnostic axis characters. Stems forming large arborescent trunks (reaching up to about 10 885 $\mathrm{cm}$ in diameter); stelar xylem siphon very thick (up to $>50$ tracheids in radial thickness), 886 moderately perforated; endodermis external and internal and connecting through leaf gaps; pith and stem cortex parenchymatous only and not differentiated into distinct layers; ca 20-35 leaf traces in a given stem transverse section; roots commonly arising from abaxial side of leaf trace within the stem cortex.

Status. Holophyletic or paraphyletic, extinct.

891 Known geochronologic range. Late Permian to Middle Triassic.

892 Comments. Guairea species are very similar to each other and sufficiently distinct from other 893 Permian Osmundales to be recognized as a genus. The close similarity of the individually scored 894 Osmundites braziliensis, which is the reason for the high BS of the according split under ML and $895 \mathrm{LS} / \mathrm{NJ}\left(\mathrm{BS}_{\mathrm{ML} / \mathrm{NJ}} \geq 75\right)$, supports its synonymy with G. carnieri (see Herbst, 1981). A Guairea896 clade would receive (moderately) high support $\left(\mathrm{BS}_{\mathrm{ML} / \mathrm{NJ} / \mathrm{MP}} \geq 67\right)$. However, the lack of 897 additional Triassic Guaireaceae fossils makes it difficult to assess the relationship of Guairea 898 and Zhongmingella to the Jurassic Lunea (they may be precursors, i.e., forming a paraphyletic 899 group, or ancient holophyletic sister lineages with no ancestor-descendant relationship). 
900 Included species:

901 • $(\dagger)$ G. carnierii (J.Schust) R.Herbst, 1981 including Osmundites braziliensis of

902 H.N.Andrews, 1950 [Late Permian: Paraguay, Rio Grande do Sul, Brazil; Middle

903 Triassic: Rio Grande do Sul, Brazil]

904 • $(\dagger)$ G. milleri R.Herbst, 1981 [Late Permian: Paraguay]

905 References. Andrews (1950), Ash (1994), Bower (1926), Herbst (1981), Herbst et al. (2012),

906 Kidston \& Gwynne-Vaughan (1914), Miller (1971), Schuster (1911), Tidwell (1991), Tidwell \& 907 Ash (1994).

908 1.1.2 (†) Genus Lunea Tidwell, 1991

909 Diagnostic characters. Stems rhizomatous to erect; stelar xylem siphon thin (less than ca 20

910 tracheids in radial thickness), moderately perforated; endodermis external only; pith and cortices

911 of stem and stipes parenchymatous with abundant scattered masses of sclerenchyma fibres; ca

912 25-35 leaf traces in a given stem transverse section; stipes lacking stipular wings and stipe

913 bundle with strongly recurved tips; roots commonly arising from abaxial side of leaf trace within

914 the stem cortex.

915 Status. Monotypic, extinct.

916 Known geochronologic range. Early Jurassic.

917 Comments. The Guaireaceae-matrix signal regarding the placement of Lunea is ambiguous (Fig.

918 10). The higher support for a Lunea + Zhongmingella clade compared to the alternative of a

919 Lunea + Guairea clade may be artificial: Lunea is relatively distinct from the (much older)

920 Guairea spp., Zhongmingella even more so, and all are substantially distinct from the members 
921 of Itopsidemoideae. There are no traits shared by Lunea and Zhongmingella to the exclusion of

922 Guairea that would support a sister relationship of the former two.

923 Included species:

924 • (†) L. jonesii Tidwell, 1991 [Early Jurassic: Tasmania, Australia]

925 References. Tidwell (1991), Ash (1994), Tidwell \& Ash (1994).

$9261.1 .3(\dagger)$ Genus Zhongmingella Shi-Jun Wang, J.Hilton, Xiao-Yuan He

927 et al., 2014

928 Diagnostic characters. Stems rhizomatous; stelar xylem siphon moderately thick (reaching up to

929 ca 30 tracheids in radial thickness), moderately perforated, dictyostelic with internal and external

930 phloem connecting through leaf gaps; pith and stem cortex parenchymatous with abundant

931 scattered fibre masses; stem cortex not differentiated into distinct layers; more than 40 leaf

932 traces in a given stem transverse section; roots commonly arising from abaxial side of leaf trace

933 within the stem cortex.

934 Status. Monotypic, extinct.

935 Known geochronologic range. Late Permian (Changhsingian).

936 Comments. The pith and cortex of Zhongmingella contain structural elements that have been

937 described variously as groups or clusters of secretory cells or of sclerenchyma (Li, 1983; Wang

938 et al., 2014b). We follow the coding in the matrix of Wang et al. (2014b) and consider these

939 elements to be sclerenchyma masses. Perhaps owing to its peculiar cortex construction with a

940 seemingly distinct innermost zone, Zhongmingella is unlike other members of Osmundales

941 according to phylogenetic reconstructions (Fig. 10).

942 Included species: 
945 References. Li (1983), Wang et al. (2014b).

\section{$9461.2(\dagger)$ Subfamily Itopsidemoideae Bomfleur, G.Grimm \& McLoughlin,}

\section{7 subfam. nov.}

948 Diagnostic characters. Stelar xylem siphon lacking discrete leaf gaps, composed of a spongy

949 admixture of metaxylem and more-or-less diffusely interspersed patches of parenchyma; stem

950 and stipe cortex primarily parenchymatous and not differentiated into distinct layers; stipes

951 lacking stipular wings and stipe bundle with recurved tips (i.e., more or less omega-shaped);

952 roots commonly arising from abaxial side of leaf trace within the stem cortex.

953 Status. Holophyletic or paraphyletic, extinct.

954 Known geochronologic range. Late Permian to Middle Triassic.

955 Comments. We consider the unique stele composition and structure of three Guaireaceae taxa-

956 Itopsidema, Donwelliacaulis, and Tiania - to be so substantially different from those of the

957 Guaireoideae to warrant the erection of this new subfamily. Itopsidemoideae might be a

958 holophyletic sister lineage of the Guaireoideae — both lineages having appeared about the same

959 time, and the unusual spongy metaxylem tissue representing a unique trait within the

960 Osmundales - or include members from which the Guaireoideae with their much more complex

961 steles have evolved, analogous to the presumed evolution of Osmundoideae from

962 Thamnopteroideae in Osmundaceae. The less complex steles in combination with traits not

963 found in Osmundaceae, account for the relatively high support for Itopsidemoideae vs. all other

964 splits for the all-inclusive $\left(\mathrm{BS}_{\mathrm{ML} / \mathrm{NJ} / \mathrm{MP}}=42 / 47 / 32\right)$ and Guaireaceae (Fig. 10) matrices. 
965 1.2.1 (†) Genus Itopsidema Daugherty, 1960

966 Diagnostic characters. Pith parenchymatous with interspersed tracheids; stelar xylem siphon

967 thin (reaching ca 20 tracheids in radial thickness), lacking discrete leaf gaps, composed of a

968 spongy admixture of metaxylem and more-or-less diffusely interspersed patches of parenchyma;

969 stem and stipe cortex primarily parenchymatous and not differentiated into distinct layers;

970 numerous (reaching >100) leaf-traces visible in a given stem transverse section; stipe bundle

971 with recurved tips (i.e., inverse omega-shaped or mushroom-shaped); stipe cortex with masses of

972 secretory cells; surface of stem and stipes covered in multicellular spines with interspersed

973 trichomes; roots commonly arising from abaxial side of leaf trace within the stem cortex.

974 Status. Monotypic, extinct.

975 Known geochronologic range. Middle Triassic.

976 Comments. Unfortunately, the diagnosis, description, and documentation of Itopsidema and its

977 type species I. vancleavei (Daugherty, 1960) followed an unconventional format that makes it

978 difficult to compare them with other, probably closely related taxa. Important information

979 missing from the protologue concerns, for instance, the origination and development of leaf-trace

980 protoxylem from the stele through the trace and into the stipe. This lack of information makes it

981 impossible at present to determine how, for instance, Tiania yunnanense (see below) differs

982 structurally from Itopsidema vancleavei; the separation of these taxa in the neighbour net (Fig. 9)

983 is partly a consequence of a poorly defined pairwise distance owing to missing data. Poor data

984 overlap may be one reason that BS analysis provides support for Itopsidema + Tiania

$985\left(\mathrm{BS}_{\mathrm{ML} / \mathrm{NJ} / \mathrm{MP}}=38 / 36 / 15\right)$ as alternative to Itopsidema + Donwelliacaulis $\left(\mathrm{BS}_{\mathrm{ML} / \mathrm{NJ} / \mathrm{MP}}=59 / 58 / 63\right.$;

986 see below).

987 Included species: 
992 Diagnostic characters. Stems exceeding $25 \mathrm{~cm}$ in diameter and forming very large arborescent 993 trunks reaching more than $40 \mathrm{~cm}$ in diameter; pith parenchymatous with interspersed tracheid 994 bundles; stelar xylem siphon very thick (reaching >70 tracheids in radial thickness), lacking 995 discrete leaf gaps, composed of a spongy admixture of metaxylem and more-or-less diffusely 996 interspersed patches of parenchyma; stem cortex primarily parenchymatous with interspersed 997 sclerenchyma masses, not differentiated into distinct layers, containing rather few (ca 20) widely 998 separated leaf traces in a given stem transverse section; stipe bundle inverse omega-shaped with 999 recurved tips.

1000 Status. Monotypic, extinct.

1001 Known geochronologic range. Middle Triassic.

1002 Comments. Hundreds of Donwelliacaulis trunk fragments have been collected from the 1003 Holbrook Member of the Moenkopi Formation of east-central Arizona (Ash, 1994), whence also 1004 the type and only specimen of Itopsidema derives (Daugherty, 1960). Owing to the small sample 1005 size and the incomplete knowledge of important diagnostic characters and about the range of 1006 variation in Itopsidema vancleavii, it remains unclear in which characters Donwelliacaulis differs 1007 structurally from Itopsidema apart from those that might be related to ontogeny and development 1008 (e.g., much larger size or fewer leaf traces). Their close relationship is reflected by the BS values 
1009 for the according split (Fig. 10). We consider the two genera to be at least closely related, and

1010 suggest that they might represent different growth stages of the same type of natural plant.

1011 Cells that were originally interpreted as protoxylem are '[...] about 24 to 36 um in diameter

1012 and with walls about 3-5 $\mu$ m thick' (Ash, 1994: p. 6). These dimensions are much too large for

1013 true protoxylem. Instead, we interpret those cells as small, early-formed metaxylem tracheids as

1014 they occur in the stele periphery of all Osmundaceae (see Ash, 1994: pl. 5, fig. 2; pl. 6, fig. 7).

1015 Hence, protoxylem maturation in Donwelliacaulis should no longer be considered exarch as

1016 originally proposed (see also remarks for Aurealcaulis).

1017 Included species:

1018 • (†) D. chlouberii Ash, 1994 [Middle Triassic: Arizona, USA]

1019 References. Ash (1994), Tidwell \& Ash (1994).

1020

\subsection{2 (†) Genus Tiania Shi-Jun Wang, J.Hilton, Galtier et al., 2014[a]}

1021 Diagnostic characters. Pith primarily parenchymatous; stelar xylem siphon thin (up to ca 10

1022 tracheids in radial thickness), lacking discrete leaf gaps, composed of a spongy admixture of

1023 metaxylem and more-or-less diffusely interspersed patches of parenchyma; stem cortex primarily

1024 parenchymatous and not differentiated into distinct layers, containing scattered masses of

1025 secretory cells and sclerenchyma; numerous (reaching >100) leaf-traces visible in a given stem

1026 transverse section; leaf-trace protoxylem single and mesarch in stele, dividing into two and

1027 becoming endarch before departure from stele; leaf trace with more than four endarch

1028 protoxylem strands upon departure from stem; roots commonly arising from abaxial side of leaf

1029 trace within the stem cortex.

1030 Status. Problematic (possibly synonymous with Itopsidema). 
1031 Known geochronologic range. Late Permian.

1032 Comments. Tiania appears to differ from Itopsidema mainly in preservational aspects and in the 1033 accompanying protologue: the former has more fully documented features of the leaf traces but 1034 lacks preserved stipes (Wang et al., 2014a), whereas the type material of the latter has a few 1035 attached stipe bases but lacks documented features of leaf-trace emission (see Daugherty, 1960).

1036 Tiania might be a junior synonym of Itopsidema, but formal taxonomic treatment should be 1037 based on a re-examination of the type material of Itopsidema and acquisition of more completely 1038 preserved axes.

1039 Included species:

1040 • (†) T. yunnanense (Bao-Lin Tian \& Jiang-Lin Chang ex Shi-Jun Wang, J.Hilton, Galtier et 1041 al.) Shi-Jun Wang, J.Hilton, Galtier et al., 2014a [Late Permian: Yunnan, China]

1042 References. Li \& Cui (1995), Wang et al. (2014a).

\section{Family Osmundaceae Martynov, 1820}

1044 (Figure 11)

1045 Diagnostic axis characters. Cortex of stems and stipes two-layered, differentiated into inner, 1046 primarily parenchymatous cylinder and outer sclerenchymatous cylinder. Stipes with a pair of 1047 stipular wings; stipe bundle with incurved tips (i.e., more or less horseshoe-shaped). Peripheral 1048 xylem siphon typically with leaf gaps [except some Thamnopteroideae].

1049 Status. Natural, possibly paraphyletic with respect to Guaireaceae, extant with fossil 1050 representatives.

1051 Known geochronologic range. Late Permian to present. 
1052 Comments. Unlike Wang et al. (2014b), we include Osmundacaulis and Shuichengella in

1053 Osmundaceae instead of Guaireaceae. We argue that Osmundacaulis may appear affiliated with

1054 Guaireaceae, and with Guairea in particular (Fig. 9), because they share several features that are

1055 highly homoplastic and are known to vary between closely related taxa or even between

1056 individuals of the same species. Such characters include the degree of stele perforation (see Vera,

1057 2008); the occurrence of simple or dissected-siphonostelic or dictyostelic conditions (see Faull,

1058 1901; Hewitson, 1962; Miller, 1971; Serbet \& Rothwell, 1999); and the occurrence of tracheids

1059 or medullary bundles in the pith (see Gwynne-Vaughan, 1914; Hewitson, 1962). Therefore, we

1060 consider the placement of Osmundacaulis closer to Guaireaceae in the trees of Wang et al.

1061 (2014b) and in the comprehensive neighbour nets presented here (Fig. 9) to be artificial and a

1062 result of a combination of long-branch attraction and overestimated signals from homoplastic

1063 features.

1064 By contrast, Osmundacaulis shares with other Osmundaceae (1) the two-layered cortex of

1065 stems and stipes with an inner, primarily parenchymatous cylinder and an outer

1066 sclerenchymatous cylinder (as opposed to a homogeneous, un-layered cortex of stems and stipes

1067 in Guaireaceae); (2) a C-shaped or horseshoe-shaped vascular bundle with more-or-less incurved

1068 tips in the stipe base (as opposed to omega-shaped or mushroom-shaped bundles with recurved

1069 tips); (3) the presence of stipular wings; and (4) the formation of a prominent mantle of many

1070 persistent leaf bases and roots (as opposed to a mantle of mainly roots with no or few persistent

1071 stipe bases). These features are invariant characteristics distinguishing Osmundaceae (including

1072 Osmundacaulis) from Guaireaceae, and represent conserved traits in all extant Osmundaceae.

1073 We consider these latter features to have much greater phylogenetic and systematic significance

1074 than those used previously, and re-assign Osmundacaulis to Osmundacaeae. Shuichengella is 
1075 also assigned to Osmundaceae based on the observation that it has a similarly two-layered

1076 cortex. The fact that it is not resolved as a close relative in the Osmundales neighbour net (Fig. 8)

1077 but nested instead within Guaireaceae is probably an analytical artefact related to the dearth of

1078 preserved diagnostic characters. No split placing Shuichengella received $\mathrm{BS}_{\mathrm{ML} / \mathrm{NJ} / \mathrm{MP}} \geq 10$. When

1079 the data matrix is reduced to only include Osmundaceae, Shuichengella groups with

1080 Osmundacaulis, and the corresponding split represents the best-supported alternative $\left(\mathrm{BS}_{\mathrm{ML} / \mathrm{NJ} / \mathrm{MP}}\right.$ $1081=42 / 32 / 22 ;$ all other alternatives $\left.\mathrm{BS}_{\mathrm{ML} / \mathrm{NJ} / \mathrm{MP}}<10\right)$. Hence, if Shuichengella is accurately

1082 interpreted as belonging to Osmundaceae, it probably is part of the same lineage that gave rise to 1083 Osmundacaulis. If future studies should produce further support for this hypothesis, it may

1084 become appropriate to re-institute the subfamily Shuichengelloideae Z.M.Li, 1993 for these two 1085 genera.

\section{$2.1(\dagger)$ Subfamily Thamnopteroideae C.N.Mill., 1971}

1087 (Figure 12)

1088 Diagnostic characters. Stems typically forming large, arborescent trunks. Stem core consisting 1089 primarily of tracheids. Peripheral metaxylem siphon typically entire and imperforate [most taxa] 1090 or with few leaf gaps [Chasmatopteris, some Thamnopteris spp.] or sparse perforations

1091 [Chasmatopteris]. Leaf-trace protoxylem initiating subexarch in peripheral bulge, becoming 1092 endarch typically in cortex. Cortex of stems and stipes two-layered, differentiated into inner, 1093 primarily parenchymatous cylinder and outer sclerenchymatous cylinder. Stipes with a pair of 1094 stipular wings; stipe bundle with incurved tips (i.e., more or less horseshoe-shaped).

1095 Status. Holophyletic or paraphyletic, extinct.

1096 Known geochronologic range. Late Permian. 
1097 Comments: Species included in this subfamily are rather similar to each other; the group-limited

1098 matrix (including Bathypteris rhomboidea, see below) comprises only 20 partly defined and

1099 variable characters (sites). Species included in Thamnopteris (nine variable sites) are generally

1100 similar in their preserved traits, hence 10 out of 55 pairwise distances are zero, and little

1101 phylogenetic structuring is evident (Fig. 12; Supplemental File S3) within the subfamily.

1102 2.1.1 (†) Genus Thamnopteris Brongn., 1849

1103 Synonyms here assigned:

1104 - Iegosigopteris Zalessky, 1935

1105 - Petcheropteris Zalessky, 1931[b]

1106 - Zalesskya Kidst. \& Gwynne-Vaughan, 1909

1107 Diagnostic characters. Stems typically forming large, arborescent trunks. Stem core consisting

1108 primarily of tracheids. Peripheral metaxylem siphon typically entire and imperforate. Leaf-trace

1109 protoxylem initiating subexarch in peripheral bulge, becoming endarch typically in cortex.

1110 Cortex of stems and stipes two-layered, differentiated into inner, primarily parenchymatous

1111 cylinder and outer sclerenchymatous cylinder. Stipes with a pair of stipular wings; stipe bundle

1112 with incurved tips (i.e., more or less horseshoe-shaped).

1113 Status. Putatively monophyletic, extinct.

1114 Known geochronologic range. Late Permian.

1115 Comments. Many species and several genera of large, 'protostelic' osmundaceous trunks have

1116 been described from Upper Permian strata of the Ural Mountains (Eichwald, 1842, 1860;

1117 Kidston \& Gwynne-Vaughan, 1908; Zalessky, 1924, 1931a, b, 1935). Zalessky himself (1935)

1118 and later Miller (1971) remarked that the delimitation of several of these genera is problematic 
1119 and probably artificial. The main feature distinguishing Petcheropteris from Thamnopteris, i.e.,

1120 the more sinuous outlines of the stipe sections in the mantle, is ' $[\ldots]$ due to compression prior to

1121 preservation' (Miller, 1971: p. 141). Iegosigopteris combines features of Thamnopteris (e.g., the

1122 more rhombic shapes of sclerenchyma rings in TS) and of Zalesskya (e.g., longer tracheids in the

1123 stem centre) (Zalessky, 1935; see Miller, 1971). Furthermore, the different tracheid length might

1124 result from a misinterpretation, since the original descriptions and illustrations (Zalessky, 1935;

1125 p. 2: fig. 1, pl. 3, fig. 2) show the stem-core tracheids to be rather short and indeed more like

1126 those of Thamnopteris. Finally, we note that the main features distinguishing Zalesskya from

1127 Thamnopteris are a greater number of leaf-traces in the cortex, a thicker inner cortex,

1128 incompletely preserved outer cortex, and missing information on mantle and petiole bases.

1129 Therefore, we see no reason to consider Zalesskya anything but a particularly large and

1130 incomplete Thamnopteris trunk. Consequently, the three genera listed above are treated here as

1131 junior synonyms of Thamnopteris.

1132 Overall, the most distinct species of the genus (pairwise distances of $0.21-0.42$ based on

1133 the Thamnopteroideae-matrix) are T.javorskii (13 out of 20 characters unambiguously defined)

1134 and T. splendida (15/20). Interspecies relationships are largely unclear; a limiting factor is the

1135 lack of overlap in the unambiguously defined characters. For instance, the 0.42 distance between

1136 T. javorskii and T. kidstonii (16/20 characters unambiguously defined) translates into six

1137 different out of 14 unambiguously defined characters for both species.

\section{Included species:}

1139 • $\dagger$ ) T. diploxylon (Kidst. \& Gwynne-Vaughan, 1908) comb. nov. [Late Permian: Russia]

1140 • (†) T. gracilis (Eichw., 1860) comb. nov. [Late Permian: Russia]

1141 • (†) T. gwynnevaughanii Zalessky, 1924 [Late Permian: Russia] 
1142

1143

1144

1145

1146

1147

1148

1149

1150

1151

1152

1153

1154

1155

1156

1157

1158

1159

1160

1161

1162

1163

- (†) T. javorskii (Zalessky, 1935) comb. nov. [Late Permian: Russia]

- (†) T. kazanensis Zalessky, 1927 [Late Permian: Russia]

- (†) T. kidstonii Zalessky, 1924 [Late Permian: Russia]

- $(\dagger)$ T. schlechtendalii (Eichw.) Brongn., 1849 [Late Permian: Russia]

- (†) T. splendida (Zalessky, 1931) comb. nov. [Late Permian: Russia]

- $(\dagger)$ T. uralica (Zalessky, 1924) comb. nov. [Late Permian: Russia]

References. Bower (1926), Brongniart (1849), Eichwald (1842, 1860), Gould (1970), Kidston \& Gwynne-Vaughan (1908, 1909), Miller (1971), Zalessky (1924, 1927, 1931b, 1935).

\subsection{2 (†) Genus Chasmatopteris Zalessky, 1931[a]}

Diagnostic characters. Stems typically forming large, arborescent trunks. Stem core consisting primarily of tracheids. Peripheral metaxylem siphon with leaf gaps and sparse perforations. Leaf-trace protoxylem initiating subexarch in peripheral bulge, becoming endarch typically in cortex. Cortex of stems and stipes two-layered, differentiated into inner, primarily parenchymatous cylinder and outer sclerenchymatous cylinder. Stipes with a pair of stipular wings; stipe bundle with incurved tips (i.e., more or less horseshoe-shaped).

Status. Monotypic, extinct.

Known geochronologic range. Late Permian.

Comments. In light of our critical reappraisal of the significance of the degree of stele perforation for systematic classification (see also Vera, 2008), one can argue whether the presence of complete perforations in the xylem siphon merits the separate generic status of Chasmatopteris principalis. This is especially so given that we propose a rather broad definition of its closest relative Thamnopteris (see above), into which C. principalis would otherwise be 
1164 merged. However, given that the entire subfamily Thamnopteroideae is otherwise composed of

1165 species with consistently imperforate xylem siphons, we consider the combination of having a

1166 stem core of more or less entirely tracheids ('protostelic') but a truly perforated ('dictyoxylic')

1167 stelar xylem siphon to be so unique as to warrant the separate generic status of C. principalis

1168 within Thamnopteroideae. Otherwise, the special significance of $C$. principalis as the single

1169 taxon having a stele construction somewhat intermediate between that of the remaining

1170 Thamnopteroideae and those of Osmundoideae might not be adequately emphasized in its

1171 systematic classification.

1172 Chasmatopteris is the most distinct (derived) known Thamnopteroideae (Fig. 12; MD =

$11730.38-0.54$ based on the Thamnopteroideae-matrix, see Supplemental File S3; the relatively low

1174 distance to $T$. kazanensis, $\mathrm{MD}=0.17$, is unrepresentative and an artefact of missing data).

1175 Should Chasmatopteris represent an extinct genus in its own right, it probably evolved from a

1176 Thamnopteris-like ancestor, rendering the latter genus paraphyletic.

1177 Included species:

1178 • (†) C. principalis Zalessky, 1931a [Late Permian: Russia]

1179 References. Zalessky (1931a), Gould (1970), Miller (1971).

$1180 \quad$ 2.2 Subfamily Osmundoideae R.Br. ex Sweet, 1826

1181 (Figure 13)

1182 Diagnostic characters. Stem core a primarily parenchymatous pith. Stelar xylem siphon usually

1183 thin (up to $c a 20$ tracheids in radial thickness) and with prominent leaf gaps. Leaf protoxylem

1184 poles initiating in mesarch position in stele, becoming endarch in stele or (rarely) in cortex.

1185 Cortex of stems and stipes two-layered, differentiated into inner, primarily parenchymatous 
1186 cylinder and outer sclerenchymatous cylinder. Inner cortex usually thinner than outer cortex,

1187 rarely about equally thick. Stipes with a pair of stipular wings; stipe bundle with incurved tips

1188 (i.e., more or less horseshoe-shaped).

1189 Status. Holophyletic, extant with fossil representatives.

1190 Known geochronologic range. Permian to present.

1191 Comments. The signal of characters instrumental for the recognition of subfamily

1192 Osmundoideae is completely outcompeted by the signal from homoplastic characters and

1193 differentiation within its sublineages in the case of the all-inclusive Osmundales matrix and the

1194 Osmundaceae matrix $\left(\mathrm{BS}_{\mathrm{ML} / \mathrm{N} J / \mathrm{P}}<10\right)$. Further taxon-reduction (81 taxa vs. 124 in the all-

1195 inclusive matrix), however, has the effect that the most distinct genera within the Osmundoideae

1196 (Palaeosmunda, Plenasium) not only receive higher support from bootstrapping (Supplemental

1197 File S3), but also become apparent in the neighbour net graphs. Notably, the Osmundoideae

1198 matrix includes $c a 25 \%$ fewer characters than the all-inclusive matrix (33 vs 45), but also has a

1199 lesser proportion of missing and ambiguous data cells (16\% vs. $20 \%)$.

\section{2.2.1 (†) Genus Palaeosmunda R.E.Gould, 1970}

1201 Diagnostic characters. Stems erect, forming arborescent trunks. Stem core a primarily

1202 parenchymatous pith. Stelar xylem siphon thin with variably developed leaf gaps. Leaf-trace

1203 protoxylem poles initially single and in mesarch position in stele, becoming endarch and, in

1204 some cases, first bifurcating before departure from stele; leaf-trace protoxylem further dividing

1205 repeatedly within stem cortex; leaf trace departing from stem with at least four (commonly more

1206 than ten) protoxylem strands. Cortex of stems and stipes two-layered, differentiated into inner,

1207 primarily parenchymatous cylinder and outer sclerenchymatous cylinder, containing few to many 
1208 (reaching ca 45) leaf traces in a given stem transverse section; inner cortex about as thick as

1209 outer cortex. Stipes with a pair of stipular wings; stipe bundle with incurved tips (i.e., more or

1210 less horseshoe-shaped); stipe sclerenchyma cylinder somewhat rhombic to fusiform in cross-

1211 section, with lateral margins usually thinner than abaxial and adaxial portions, distally

1212 becoming extended laterally into flanges that partially or completely replace the stipules.

1213 Status. Probably holophyletic, extinct.

1214 Known geochronologic range. Late Permian, possibly extending to the Late Triassic.

1215 Comments. The position of Palaeosmunda with respect to the other Osmundoideae genera and

1216 in particular the (putatively) paraphyletic Millerocaulis is not entirely clear (Fig. 13).

1217 Independent of the optimality criterion used, bootstrapping fails to recover any preferred

1218 placement of Palaeosmunda within alternative tree topologies $\left(\mathrm{BS}_{\mathrm{ML} / \mathrm{NJ} / \mathrm{MP}}\right.$ of all possible

1219 alternatives $<10$ ). Nevertheless, the genus seems to represent an early-diverged, distinct sister

1220 lineage when analysed in a larger taxonomic context (Figs 9, 11). Both their morphology (see

1221 Diagnostic characters; Fig. 6) and stratigraphic occurrence (Upper Permian to possibly Upper

1222 Triassic) can be taken as arguments against the alternative hypotheses that this genus represents a

1223 lineage that evolved from a Millerocaulis-type ancestor, or that it could represent the ancestral

1224 stock from which the remaining Osmundoideae evolved. 'Millerocaulis' stipabonettiorum has

1225 several features that are unusual among Millerocaulis species and more reminiscent of

1226 Palaeosmunda (Herbst, 1995); the most conspicuous similarities are the rhombic to fusiform

1227 shape of the stipe sclerenchyma rings and the absence of sclerenchyma patches or fibres

1228 associated with either leaf traces or stipe vascular bundles (Herbst, 1995). Unfortunately,

1229 protoxylem - whose distribution and development should enable unambiguous assignment to

1230 either Millerocaulis or Palaeosmunda - is not preserved in the single available specimen. 
1231 Nevertheless, since (1) we refrain from using Millerocaulis as a 'waste-basket taxon' for left-

1232 over species that cannot be positively assigned to any of the other taxa of Osmundoideae; (2) all

1233 our subset analyses consistently place 'Millerocaulis' stipabonettiorum closer to Palaeosmunda

1234 than to any other representative of Millerocaulis (the only splits involving 'Millerocaulis'

1235 stipabonettiorum receiving $\mathrm{BS}_{\mathrm{ML} / \mathrm{NJ}}>10$ are those with Palaeosmunda or one of its species); and

1236 (3) generic assignment of this species should thus be considered provisional anyway, we

1237 tentatively group 'Millerocaulis' stipabonettiorum with Palaeosmunda and exclude it from our

1238 analyses of Millerocaulis (Fig. 13).

1239 Included species:

1240 • (†) P. playfordii R.E.Gould, 1970 [Late Permian: Queensland, Australia]

1241 • (†) P. williamsii R.E.Gould, 1970 [Late Permian: Queensland, Australia]

1242 Tentatively included:

$1243 \quad \bullet(\dagger)$ 'Millerocaulis’ (?Palaeosmunda) stipabonettiorum [Late Triassic: Argentina]

1244 References. Gould (1970), Herbst (1995), McLoughlin (1992); see also Li (1983).

$12452.2 .2(\dagger)$ Genus Millerocaulis Erasmus ex Tidwell emend. E.I.Vera,

12462008

1247 (Figure 14)

1248 Diagnostic characters. Stems usually rhizomatous to small (semi-)erect. Stem core a primarily

1249 parenchymatous pith. Stelar xylem siphon usually thin (up to ca 20 tracheids in radial thickness)

1250 and with prominent leaf gaps. Protoxylem poles in stele initially single and mesarch, becoming

1251 endarch in stele or (rarely) in cortex. Cortex of stems and stipes two-layered, differentiated into

1252 thin inner, primarily parenchymatous cylinder and thick outer sclerenchymatous cylinder. Stipes 
1253 with a pair of stipular wings; stipe bundle with incurved tips (i.e., more or less horseshoe-

1254 shaped). Sclerenchyma ring in stipe base circular to elliptic in cross-section, homogenous to

1255 gradually or diffusely heterogeneous.

1256 Status. Probably paraphyletic with respect to Osmundeae.

1257 Known geochronologic range. Triassic to mid-Cretaceous.

1258 Comments. Vera (2008) proposed merging Millerocaulis Erasmus ex Tidwell emend. Tidwell

1259 (1994; with imperforate steles) and Ashicaulis Tidwell (1994; with perforate steles) into a single

1260 genus, the broadly defined Millerocaulis Tidwell emend. E.I.Vera, which we follow here.

1261 Members of Millerocaulis, explicitly circumscribed here as a paraphyletic taxon, can be

1262 either precursors or belong to sister lineages of the 'modern' Osmundaceae (classified as

1263 Osmundeae). In the light of the notable size and disparity of the genus, it is tempting to

1264 subdivide it further. With the available information, however, a consistent further subdivision is

1265 difficult to achieve. The neighbour net focussing on Millerocaulis is essentially a 'spider-web'

1266 (Fig. 14), and the same holds true for support consensus networks (Supplemental Data Archive),

1267 illustrating the lack of consistent sorting signals in the underlying matrix. The traditional

1268 subdivision based on the degree of stele perforation (informal groups as in the listing below) is,

1269 therefore, not supported by any further evidence. Furthermore, the data compiled here show that

1270 imperforate and highly perforate steles are end members of a complete transformation series in

1271 Osmundoideae and, thus, provide a poor basis for classification above species level. A much

1272 deeper understanding of character conservation and evolution in the Osmundoideae would be

1273 necessary to propose a finer subdivision. Moreover, it is conspicuous that the net (Fig. 14) shows

1274 several boxes that are composed of species of similar age and similar geographic occurrence that

1275 plot closely together (e.g., Millerocaulis limewoodensis with M. dunlopii and M. aucklandicus all 
1276 from the Middle Jurassic of eastern Australasia); we suspect that more complete knowledge of

1277 the natural variability of anatomical features of the constituent species might prove some of those

1278 to represent variants of the same natural species, as has been suggested for M. dunlopii and $M$.

1279 aucklandicus (Miller, 1971; Tidwell, 1986; zero pairwise distance here). Further potential sister

1280 species pairs including candidates for further taxonomic revision are listed in Table 1. The

1281 association of the Triassic M. herbstii with the Cretaceous M. kolbei is probably an artefact: both

1282 taxa differ from all other Millerocaulis as much as from each other.

1283 Although Millerocaulis is defined mainly on the absence of traits diagnostic of other

1284 genera of Osmundoideae, it should not be considered a 'waste-basket' or 'form-taxon' for

1285 Osmundoideae of uncertain affinity. We suggest that if in a new fossil osmundoid rhizome

1286 critical characters, such as stelar xylem siphon or the stipe sclerenchyma ring, are not adequately

1287 preserved, or if the fossil in question is insufficiently comparable with other fossil osmundoid

1288 taxa, it should not automatically be described as a new Millerocaulis species. Instead, we suggest

1289 that such specimens should be described in open nomenclature and labelled with the lowest

1290 taxonomic rank to which they can be confidently assigned (e.g., "undetermined osmundoid

1291 rhizome" or "Osmundoideae gen. and sp. indet."). The name Millerocaulis should be reserved

1292 for Osmundoideae rhizomes with a distinctly plesiomorphic character suite compared with the

1293 other genera of the subfamily and, in particular, Osmundeae.

\section{Included species:}

1295 'Millerocaulis s.str.' group (low degree of stele perforation; see Char. 8):

1296 - (†) M. chubutensis (R.Herbst) Tidwell, 1994 [Late Jurassic: Argentina]

1297 • $\dagger$ M. Monponii Tidwell \& Clifford, 1995 [Middle Jurassic: Australia] 
1298

1299

1300

1301

1302

1303

1304

1305

1306

1307

1308

1309

1310

1311

1312

1313

1314

1315

1316

1317

1318

1319

1320

- (†) M. dunlopii (Kidst. \& Gwynne-Vaughan) Tidwell, 1994, including Osmundites aucklandicus P.Marshall, 1926 [Middle Jurassic: New Zealand]

- $(\dagger)$ M. indicus (B.D.Sharma) Tidwell, 1994 [Early Cretaceous: India]

- (†) M. juandahensis Tidwell \& Clifford, 1995 [Middle Jurassic: Australia]

- (†) M. limewoodensis Tidwell \& Clifford, 1995 [Middle Jurassic: Australia]

'Ashicaulis' group (moderate degree of stele perforation; see Char. 8):

- (†) M. amarjolensis (B.D.Sharma) Tidwell, 1986 [Early Cretaceous: India]

- $(\dagger)$ M. australis (E.I.Vera) E.I.Vera, 2008 [Early Cretaceous: West Antarctica]

- (†) M. beipiaoensis (N.Tian, Y.D.Wang, Wu Zhang et al., 2013) comb. nov. [Middle Jurassic: Liaoning, China]

- (†) M. broganii Tidwell, Munzing \& M.R.Banks, 1991 [?Triassic: Tasmania, Australia]

- (†) M. gibbianus (Kidst. \& Gwynne-Vaughan) Tidwell, 1986 [Middle Jurassic: New Zealand]

- (†) M. guptai (B.D.Sharma) Tidwell, 1986 [Early Cretaceous: India]

- (†) M. hebeiensis (Ziquiang Wang) Tidwell, 1986 [Middle Jurassic: Hebei, China]

- (†) M. herbstii (S.Archang. \& de la Sota) Tidwell, 1986 [Late Triassic: Argentina]

- $(\dagger)$ M. livingstonensis (Cantrill) E.I.Vera, 2008 [Late Cretaceous: West Antarctica]

- (†) M. lutziae (R.Herbst) R.Herbst, 2006 [Late Triassic: Argentina]

- (†) M. macromedullosus (M.Matsumoto, K.Saiki, Wu Zhang et al.) E.I.Vera, 2008 [Middle Jurassic: Hebei, China]

- (†) M. patagonicus (S.Archang. \& de la Sota) Tidwell, 1986) [Middle-Late Jurassic: Argentina]

- (†) M. rajmahalensis (K.M.Gupta) Tidwell, 1986 [Early Cretaceous: India] 
1321

1322

1323

1324

1325

1326

1327

1328

1329

1330

1331

1332

1333

1334

1335

1336

1337

1338

1339

1340

1341

- $(\dagger)$ M. richmondii Tidwell, 1992 [?Triassic: Tasmania, Australia]

- $(\dagger)$ M. sahnii (Vishnu-Mittre) Tidwell, 1986 [Early Cretaceous: India]

- (†) M. santaecrucis (R.Herbst) R.Herbst, 1995 [Middle-Late Jurassic: Argentina]

- $(\dagger)$ M. spinksii Tidwell, Munzing \& M.R.Banks, 1991 [?Triassic: Tasmania, Australia]

- (†) M. swanensis Tidwell, Munzing \& M.R.Banks, 1991 [?Triassic: Tasmania, Australia]

- $(\dagger)$ M. wadei (Tidwell \& S.R.Rushforth) Tidwell, 1986 [Late Jurassic: Utah, USA]

- $(\dagger)$ M. websteri Tidwell, Munzing \& M.R.Banks, 1991 [?Triassic: Tasmania, Australia]

- (†) M. woolfei (G.W.Rothwell, Ed.L.Taylor \& T.N.Taylor) E.I.Vera, 2008 [Middle Triassic: East Antarctica]

- (†) M. wrightii Tidwell, Munzing \& M.R.Banks, 1991 [?Early Jurassic: Tasmania, Australia]

'Millerocaulis kolbei' type (high degree of stele perforation; see Char. 8)

- $(\dagger)$ M. kolbei (Seward) Tidwell, 1986 [Cretaceous: South Africa]

References. Archangelsky \& de la Sota (1962, 1963), Bower (1926), Cantrill (1997), Cheng (2011), Cheng \& Li (2007), Cheng et al. (2007), Edwards (1933), Gupta (1970), GwynneVaughan (1911), Herbst (1977, 1994, 1995, 2001, 2006, 2008), Kidston \& Gwynne-Vaughan (1907, 1910), Marshall (1926), Matsumoto et al. (2006), Miller (1971), Prynada (1974), Rothwell et al. (2002), Seward (1907), Sharma (1973), Sinnott (1914), Tian et al. (2008, 2013, 2016), Tidwell (1986, 1992, 1994, 2002), Tidwell \& Ash (1994), Tidwell \& Clifford (1995), Tidwell \& Rushforth (1970), Tidwell et al. (1991), Vera (2007, 2008, 2010), Vishnu-Mittre (1955), Wang (1983). 
1342 2.2.3 Tribus Osmundeae Hook. ex Duby, 1828 ('modern’ Osmundaceae)

1343 (Figure 15)

1344 Diagnostic axis characters. Stem core a primarily parenchymatous pith. Stelar xylem siphon 1345 typically thin (up to 15 , rarely up to 20 tracheids in radial thickness) and with prominent leaf 1346 gaps. Leaf protoxylem poles initiating in mesarch position in stele, becoming endarch in stele or 1347 (rarely) in cortex. Cortex of stems and stipes two-layered, differentiated into inner, primarily 1348 parenchymatous cylinder and outer sclerenchymatous cylinder. Inner cortex usually thinner than 1349 outer cortex. Stipes with a pair of stipular wings; stipe bundle with incurved tips (i.e., more or 1350 less horseshoe-shaped). Stipe sclerenchyma ring heterogeneous: differentiation beginning in the 1351 stipe base usually with the formation of an abaxial arch of particularly thick-walled fibres that, 1352 distally, may differentiate further into massive sclerotic rings, patches, or arches in 1353 characteristic configurations.

1354 Status. Natural, holophyletic.

1355 Known geochronological range. Triassic to present.

1356 Comments. Traditionally, the occurrence of a heterogenous sclerenchymatic ring in the stipe 1357 bases has been used to differentiate modern Osmundaceae (genera with extant taxa:

1358 Claytosmunda, Osmunda, Osmundastrum, Plenasium, Leptopteris, Todea) from extinct, ancient 1359 Osmundoideae (Ashicaulis-Millerocaulis group; Osmundacaulis sensu Miller; Palaeosmunda).

1360 Under the widely shared assumption that all extant Osmundaceae are holophyletic (e.g., Metzgar 1361 et al., 2008; Bomfleur et al., 2015; PPG I, 2016; Testo \& Sundue, 2016), the heterogenous ring 1362 represents the synapomorphy for this clade. Thus, all fossil taxa with heterogenous sclerenchyma 1363 rings showing similar differentiation from an abaxial arch of thick-walled fibres should be 1364 classified as members of one of the modern genera, or be accommodated in new genera if they 
1365 have character suites that clearly distinguish them from extant Osmundeae. We recognize two

1366 mutually holophyletic subtribes (see Bomfleur et al. 2015; but see Yatabe et al., 1999, Metzgar et

1367 al. 2008): Todeinae, the lineage leading to and including Leptopteris and Todea, and

1368 Osmundinae (former genus Osmunda), the lineage including Claytosmunda, Osmunda,

1369 Osmundastrum, and Plenasium with two subgenera (Aurealcaulis and Plenasium).

\subsubsection{Subtribus Todeinae Bomfleur, G.Grimm \& McLoughlin subtrib.}

1371 nov.

1372 Diagnostic stem characters. Stem core a primarily parenchymatous pith. Stelar xylem siphon

1373 typically thin (up to 15 tracheids in radial thickness) and with prominent leaf gaps. Leaf

1374 protoxylem poles initiating in mesarch position in stele, becoming endarch in stele or (rarely) in

1375 cortex, first bifurcating as leaf-trace departs from stem. Cortex of stems and stipes two-layered,

1376 differentiated into inner, primarily parenchymatous cylinder and outer sclerenchymatous

1377 cylinder; inner stem cortex usually thinner than outer stem cortex; outer stem cortex

1378 heterogeneous, with a distinct ring of fibres surrounding each leaf trace. Stipes with a pair of

1379 stipular wings; stipe bundle with incurved tips (i.e., more or less horseshoe-shaped); stipe

1380 sclerenchyma ring heterogeneous, differentiating upwards into a thin band of particularly thick-

1381 walled fibres forming the outer margin of the sclerenchyma ring.

1382 Status. Holophyletic; extant with fossil representatives.

1383 Known geochronologic range. Early Cretaceous to present.

1384 Comments. Our concept of a Todeinae subtribe inferred solely on the basis of stem anatomy is

1385 equivalent to the informal 'leptopteroid clade' of Escapa and Cuneo (2012) inferred from the

1386 frond-compression fossil record. Stems of Todeinae are readily distinct from those of their 
1387 potential sister clade Osmundinae (cf. Bomfleur et al., 2015; but see Yatabe 1999 and Metzgar et

1388 al., 2008). Detailed analysis of rhizome evolution and more fossils representing this lineage will

1389 be needed to decide whether the Todeinae stems $(i)$ can be derived from the basic type

1390 represented in Osmundinae ('paraphyletic Osmunda' scenario discussed by Bomfleur et al.,

13912015 ) or (ii) represent their actual sister lineage ('monophyletic Osmunda' scenario of Bomfleur

1392 et al., 2015). An important question in this context is also whether Osmundaceae foliage (Todea-

1393 type vs. Claytosmunda/Osmundastrum-type) found from the Triassic onwards (see Escapa et al.,

1394 2012; Grimm et al., 2015), can be associated with either one of the subtribes. So far, only two

1395 relatively young stem fossils with characteristic Todeinae anatomy have been found. Todeinae

1396 may simply be greatly under-represented in the fossil rhizome record, or earliest (pre-

1397 Cretaceous) Todeinae had a less differentiated, Osmundinae-like stem.

1398 2.2.3.1.1 Genus Todea Willd. ex Bernh., 1801

1399 Diagnostic axis characters. Stem core a primarily parenchymatous pith. Stelar xylem siphon

1400 typically thin (generally less than 10, rarely reaching 15 cells in radial thickness) and with

1401 prominent leaf gaps. Leaf protoxylem poles initiating in mesarch position in stele, becoming

1402 endarch in stele or (rarely) in cortex, first bifurcating as leaf-trace departs from stem. Cortex of

1403 stems and stipes two-layered, differentiated into inner, primarily parenchymatous cylinder and

1404 outer sclerenchymatous cylinder; inner stem cortex usually thinner than outer stem cortex,

1405 containing a patch of thick-walled fibres adaxial to each leaf trace; outer stem cortex

1406 heterogeneous, with a distinct ring of fibres surrounding each leaf trace. Stipes with a pair of

1407 stipular wings; stipe bundle with incurved tips (i.e., more or less horseshoe-shaped); stipe inner

1408 cortex with numerous small sclerenchyma strands scattered throughout; stipe sclerenchyma ring 
1409 heterogeneous, differentiating upwards into a thin band of particularly thick-walled fibres

1410 forming the outer margin of the sclerenchyma ring.

1411 Status. Holophyletic, extant with one putative fossil representative

1412 Known geochronologic range. Early Cretaceous to present.

1413 Comments. Recent phylogenetic analyses support the inclusion of the fossil Todea tidwellii in

1414 the Todea-Leptopteris lineage, but are ambiguous regarding the question whether it represents a 1415 potential precursor or relative of modern Todea (making Todea as defined here holophyletic) or 1416 related to the common ancestor of Todea and Leptopteris (making Todea, as defined here, 1417 paraphyletic) (Bomfleur et al., 2015). The Early Cretaceous age of T. tidwellii coincides with the 1418 estimated divergence of the two extant genera and would allow for both scenarios (Grimm et al., 1419 2015). In the neighbour nets used here, T. tidwellii groups consistently with $T$. barbara (see also 1420 Table 2), and a corresponding clade would receive moderate to high support for all matrices 1421 including these taxa $\left(\mathrm{BS}_{\mathrm{ML}}=64-73 ; \mathrm{BS}_{\mathrm{LS}}=66-75 ; \mathrm{BS}_{\mathrm{MP}}=43-52\right)$, which provides ample 1422 support for the conclusion of Jud et al. (2007) that $T$. tidwellii is an early respresentative of the 1423 modern genus Todea.

\section{Included species:}

1425 - T. barbara (L.) T.Moore, 1857 [Extant: South Africa, Australia].

1426 - T. papuana Hennipman, 1968 [Extant: Papua New Guinea].

1427 - (†) T. tidwellii Jud, G.W.Rothwell \& Stockey, 2008 [Early Cretaceous: British Columbia, 1428 Canada].

1429 References. Seward \& Ford (1903), Bower (1926), Gwynne-Vaughan (1911), Hewitson (1962), 1430 Kidston \& Gwynne-Vaughan (1907), Miller (1971), Jud et al. (2008). 
1431 2.2.3.1.2 Genus Leptopteris C.Pres1, 1845

1432 Diagnostic axis characters. Stem core a primarily parenchymatous pith. Stelar xylem siphon

1433 typically thin (up to 15 , rarely up to 20 tracheids in radial thickness) and with prominent leaf

1434 gaps. Leaf protoxylem poles initiating in mesarch position in stele, becoming endarch in stele or

1435 (rarely) in cortex, first bifurcating as leaf-trace departs from stem. Cortex of stems and stipes

1436 two-layered, differentiated into inner parenchymatous cylinder and outer sclerenchymatous

1437 cylinder; inner stem cortex usually thinner than outer cortex, lacking sclerenchyma patches;

1438 outer stem cortex heterogeneous, with a distinct ring of fibres surrounding each leaf trace. Stipes

1439 with a pair of stipular wings; stipe bundle with incurved tips (i.e., more or less horseshoe-

1440 shaped); stipe inner cortex lacking sclerenchyma strands; stipe sclerenchyma ring

1441 heterogeneous, differentiating distally into a thin band of particularly thick-walled fibres forming

1442 the outer margin of the sclerenchyma ring.

1443 Status. Holophyletic, extant with one equivocal fossil record.

1444 Known geochronologic range. Possibly Early Cretaceous to present.

1445 Comments. A single, rather poorly preserved specimen of a fossil osmundaceous stem from

1446 Lower Cretaceous strata of the Rajmahal Hills, India, was described under the name

1447 Osmundacaulis estipularis B.D.Sharma, D.Bohra \& R.Singh (Sharma et al. 1979). The species

1448 was supposed to be distinct from most other Osmundaceae in lacking stipular wings (hence the

1449 epithet estipularis = lat. 'without stipules'). We disagree with this assumption, and point out

1450 several features of the specimen based on which we propose an alternative interpretation: (1)

1451 preservation of the holotype is imperfect, and parenchyma is mostly lacking throughout the

1452 specimen; (2) there are abundant transverse sections of unusually thick roots visible between the

1453 sclerenchyma cylinders of stipes throughout the mantle of the trunk; and (3) the composition of 
1454 the outer stem cortex appears heterogeneous with clearly distinct rings surrounding each leaf

1455 trace already in the outer cortex. Based on these observations we argue that the type and only

1456 specimen of $O$. estipularis represents a poorly preserved fossil of an arborescent osmundoid

1457 trunk in which the strong vertical roots penetrating downwards through the mantle, together with

1458 the imperfect preservation of parenchyma, hamper the identification of stipular wings.

1459 Furthermore, the outer stem cortex is heterogeneous in a manner typical of Todea and

1460 Leptopteris, and what is visible of the inner cortex shows no evidence of sclerenchyma patches

1461 that would be diagnostic of Todea; in fact, the entire aspect of the specimen is very similar to the

1462 basal stem section of the extant arborescent Leptopteris wilkesiana reproduced by Miller (1971:

1463 compare figs 3 and 4 of Plate II), in which the roots have removed most of the parenchymatic

1464 stipular wings. We hypothesize that this specimen represents the only known fossil trunk of a 1465 Leptopteris yet discovered, but definite assignment should await a re-investigation of the type 1466 material.

1467 In contrast to Todea, character suites of Leptopteris rhizomes provide a highly ambiguous 1468 phylogenetic signal as reflected in the much lower supports for a potential Leptopteris clade $1469\left(\mathrm{BS}_{\mathrm{ML} / \mathrm{LS} / \mathrm{MP}} \leq 16\right.$ including the fossil described as Osmundacaulis estipularis; $\mathrm{BS}_{\mathrm{ML}}<10, \mathrm{BS}_{\mathrm{LS}}=$ $147026-34 ; \mathrm{BS}_{\mathrm{MP}}=16-18$ for a clade comprising all extant species). Under ML, a competing,

1471 presumably inaccurate split (see, e.g., Metzgar et al. 2008; Bomfleur et al. 2015; see also Fig. 15) 1472 associates the extant Leptopteris fraseri with the Todea $\mathrm{spp} .\left(\mathrm{BS}_{\mathrm{ML}}=39-47\right)$. Mutual holophyly 1473 of Leptopteris and Todea, however, is well-supported by distance data (Fig. 15; Table 2).

\section{Included species:}

1475 - L. fraseri (Hook. \& Grev.) C.Presl, 1845 [Extant: Australia]

1476 - L. hymenophylloides (A.Rich.) C.Presl, 1845 [Extant: Australia, New Zealand] 
1477

1478

1479

1480

1481

1482

1483

1484 (1971); see also Sharma et al. (1979).

Tentatively included: Cretaceous: India]

\section{5}

1486

1487

1488

1489

1490

1491

1492

1493

1494

1495

1496 1497 fibres.

1498 Status. Holophyletic (cf. Bomfleur et al. 2015), extant with fossil representatives.

\subsubsection{Subtribus Osmundinae Bomfleur, G.Grimm \& McLoughlin}

subtrib. nov.

(Fig. 16)

Diagnostic stem characters. Stem core a primarily parenchymatous pith. Stelar xylem siphon typically thin (up to ca 20, rarely up to 25 tracheids in radial thickness) and with prominent leaf gaps. Leaf protoxylem poles initiating in mesarch position in stele, becoming endarch in stele or (rarely) in cortex. Cortex of stems and stipes two-layered, differentiated into inner, primarily parenchymatous cylinder and outer sclerenchymatous cylinder; outer stem cortex homogeneous, thicker than inner stem cortex. Stipes with a pair of stipular wings commonly containing strands of thick-walled fibers of various shapes and sizes; stipe bundle with incurved tips (i.e., more or less horseshoe-shaped). Stipe sclerenchyma ring heterogeneous: differentiation typically initiating in the stipe base with the formation of an abaxial arch of particularly thick-walled

- L. superba (Colenso) C.Presl, 1848 [Extant: Australia, New Zealand]

- L. wilkesiana (Brack.) Christ, 1897 [Extant: Tropical Pacific Islands including Fiji, Samoa, Vanuatu, New Caledonia, and possibly others]

- $(\dagger)$ ?Leptopteris estipularis (B.D.Sharma, D.Bohra \& R.Singh, 1979) comb. nov. [Early

References. Bower (1926), Hewitson (1962), Kidston \& Gwynne-Vaughan (1907), Miller 
1499 Known geochronologic range. Triassic to present.

1500 Comments. In analyses of molecular datasets that are based also on conserved coding

1501 chloroplast and mitochondrial genes, the outgroup-inferred root is consistently placed between

1502 Osmundastrum and a clade comprising all remaining extant Osmundaceae (Yatabe et al., 1999;

1503 Metzgar et al., 2008). Combining several lines of evidence, such as detailed analysis of the signal

1504 from molecular data, fossilized birth-death dating using frond fossils, rhizome anatomical

1505 evidence, and hybridisation capacity, Bomfleur et al. (2015) argued that this is an outgroup-

1506 ingroup (long) branching artefact. In a recent comprehensive pteridophyte analysis aiming to

1507 capture rate shifts in the evolution of fern lineages (Testo \& Sundue, 2016), the distances

1508 between the hypothetical most recent common ancestor (MRCA) of living Osmundaceae to the

1509 extant species is much smaller than the distances between the Osmundaceae-MRCA and the

1510 Osmundaceae root based on fossil evidence and between the Osmundaceae-MRCA and the -tips

1511 and the root-tips of Marattiales (having diverged earlier) and Hymenophyllaceae (having

1512 diverged later; PPG I, 2016; Testo \& Sundue, 2016). In such a case, ingroup-outgroup (long)

1513 branching artefacts and accordingly misplaced ingroup roots may be inevitable. Thus, we see no

1514 reason to not recognize Osmundinae as holophyletic (Bomfleur et al., 2015; Grimm et al., 2015).

1515 With respect to axis anatomy, the signals from the few but consistent traits that differentiate

1516 members of Millerocaulis, Todeinae and Osmundinae appear to become outcompeted by signals

1517 from convergent traits. Moreover, some early members of Osmundinae (especially of

1518 Claytosmunda) lack the derived features typical of its modern relatives, and have many

1519 presumably primitive traits shared with species of Millerocaulis. Consequently, pairwise

1520 distances between (early) members of the Osmundinae and of Millerocaulis can be smaller than 
1521 those within each lineage, which may explain the poor support for an Osmundinae clade and the

1522 Osmundastrum and Osmunda-lineages (Table 3).

1523 In the case of Osmundinae and its genera, the practical advantage of an 'evolutionary'

1524 classification (Fig. 8G,H) in contrast to a strict 'cladistic' classification (Fig. 8D,E) becomes

1525 vital. Even if unambiguous fossil evidence should prove that Todeinae evolved from an

1526 Osmundinae-like ancestor and confirm the outgroup-defined root, Osmundinae can remain valid 1527 and usable as a well-defined paraphyletic taxon. A cladistic classification, on the other hand, 1528 would require major taxonomic changes: in addition to rejecting the subtribe subdivision, many 1529 early Osmundinae axes would need to remain nameless (see comments below for each genus).

1530 We follow PPG I (2016) in recognising four genera in the Osmundinae, which have mostly 1531 been treated as subgenera of Osmunda. Even though this subdivision is supported also by 1532 vegetative and reproductive features and by molecular data (see Bomfleur et al., 2015), all four 1533 genera can be diagnosed and well distinguished solely on the basis of axis anatomy. Three of the 1534 genera are (likely) holophyletic (Osmundastrum, Osmunda, Plenasium), whereas Claytosmunda, 1535 which probably represents the most primitive suite of axis anatomical characters (see Bomfleur 1536 et al. 2015), is monotypic but paraphyletic (Claytosmunda) when fossils are included.

\section{2.2.3.2.1 Genus Claytosmunda (Y.Yatabe, N.Murak. \& K.Iwats.)}

1538 Metzgar \& Rouhan, 2016

1539 Diagnostic axis characters. Stem core a primarily parenchymatous pith. Stelar xylem siphon 1540 typically thin (up to 15, rarely up to 20 tracheids in radial thickness) and with prominent leaf 1541 gaps. Leaf protoxylem poles initiating in mesarch position in stele, becoming endarch in stele or 1542 (rarely) in cortex, first bifurcating in outermost cortex or outside the stem. Cortex of stems and 
1543 stipes two-layered, differentiated into inner, primarily parenchymatous cylinder and outer

1544 sclerenchymatous cylinder; outer stem cortex homogeneous, thicker than inner stem cortex.

1545 Stipes with a pair of stipular wings commonly containing strands of thick-walled fibers of

1546 various shapes and sizes; stipe bundle with incurved tips (i.e., more or less horseshoe-shaped).

1547 Stipe sclerenchyma ring heterogeneous with an abaxial arch of particularly thick-walled fibres

1548 that may further develop into two opposite, separate or thinly connected lateral masses.

1549 Status. Partly ancestral (paraphyletic per definition) to Osmunda, Plenasium, and possibly

1550 Osmundastrum; extant with fossil representatives.

1551 Known geochronologic range. Middle Triassic to present.

1552 Comments. In a previous phylogenetic analysis with fewer characters and fewer operational

1553 units, we concluded that '[...] a subdivision into two putatively monophyletic subgenera

1554 Osmunda sensu Yatabe et al. and Claytosmunda generates two taxa without discriminating

1555 anatomical and morphological features' (Bomfleur et al., 2015, pp. 15f). Based on the more

1556 comprehensive analysis of structural and morphological characters in Osmundales presented

1557 here, however, we agree that species of Claytosmunda are in fact distinguishable from the

1558 remaining Osmunda species based on the combination of (italicized) anatomical characters as

1559 outlined above. The plesiomorphic features of Claytosmunda include the protoxylem division

1560 occurring only outside the stem (shared with Osmundastrum) and the sporadic occurrence of

1561 mesarch leaf traces in the inner or rarely outer cortex (the one prominent difference between $C$.

1562 beardmorensis and C. claytoniana, as far as the two species can be compared). The main

1563 diagnostic rhizome trait is the composition of the heterogenous sclerenchymatic ring in the leaf

1564 trace. 
Claytosmunda. In most cases, the similarity and inferred relationship of each of these species to

1567 Osmundinae in general and to genus Claytosmunda in particular (i.e., including also some

1568 species of Osmunda sensu Miller, 1971) has already been suggested by the original authors in the

1569 respective comparative discussion. For example, having noted the remarkable similarity of

1570 Osmunda plumites to C. claytoniana, Tian and colleagues noted that the species '[...] should

1571 also be a member of this paraphyly' (Tian et al., 2014a: p. 217). Also Claytosmunda chengii, $C$.

1572 preosmunda, C. sinica, C. tekelili, and C. wangii were immediately interpreted to be close

1573 relatives and possible precursors of Claytosmunda claytoniana, the only extant representative of

1574 the genus (Cheng \& Li, 2007: p. 258; Cheng et al., 2007: pp. 1357f.; Cheng, 2011: p. 102; Vera,

1575 2012: p. 43; Tian et al., 2014b). Precursors of the remaining lineages Osmunda, Plenasium, and,

1576 possibly, Osmundastrum would probably be diagnosed as members of Claytosmunda. The

1577 paraphyletic nature of species with Claytosmunda-rhizome anatomy is well represented in the

1578 neighbour net, where species included in this genus occupy positions between the better defined

1579 (morphologically more distinct) genera of the Osmundinae (Fig. 16; or Osmundeae: Figs 11, 13,

1580 15). Claytosmunda is more or less equally similar to all other members of Osmundeae and shows

1581 no apparent preference towards any extant species. Accordingly, no member of Claytosmunda,

1582 including the extant C. claytoniana, would be supported as a member of a clearly defined clade

$1583\left(\mathrm{BS}_{\mathrm{ML} / \mathrm{LS} / \mathrm{MP}} \leq 10\right.$; Supplemental File S3; see the BS support networks in the Supplemental Data

1584 Archive).

1585 Although Claytosmunda nathorstii from the Palaeogene of Svalbard is known only from

1586 isolated stipes and was thus excluded from the phylogenetic analyses owing to it lacking too

1587 many characters, the species is clearly allied with Claytosmunda based on its characteristic stipe 
1588 structure with two lateral masses of thick-walled fibres in the sclerenchyma cylinder and with an

1589 elongate mass of fibres in each stipular wing (Miller, 1967).

1590 Included species:

1591 - C. claytoniana (L., 1753) comb. nov. [Extant: East Asia and eastern North America]

1592 - $\dagger$ C. beardmorensis (J.M.Schopf, 1978) comb. nov. [Middle Triassic: East Antarctica]

$1593 \quad \bullet(\dagger)$ C. chengii nom. nov. [Middle Jurassic: Liaoning, China]

1594 - $\dagger$ ) C. johnstonii (Tidwell, Munzing \& M.R.Banks, 1991) comb. nov. [?Early Jurassic:

$1595 \quad$ Tasmania, Australia]

1596 - (†) C. embreii (Stockey \& S.Y.Sm., 2000) comb. nov. [Early Cretaceous: California, USA]

1597 - $(\dagger)$ C. liaoningensis (Wu Zhang \& Shao-Lin Zheng, 1991) comb. nov. [Middle Jurassic:

$1598 \quad$ Liaoning, China]

$1599 \quad \bullet(\dagger)$ C. nathorstii (C.N.Mill., 1967) comb. nov. [Palaeogene: Svalbard

1600 - $(\dagger)$ C. plumites (N.Tian \& Y.D.Wang, 2014a) comb. nov. [Middle Jurassic: Liaoning, 1601 China].

1602 - $\dagger_{\dagger}$ C. preosmunda (Y.M.Cheng, Yu F.Wang \& C.S.Li, 2007) comb. nov. [Middle Jurassic:

$1603 \quad$ Liaoning, China]

1604 - $(\dagger)$ C. sinica (Y.M.Cheng \& C.S.Li, 2007) comb. nov. [Middle Jurassic: Liaoning, China]

1605 - $(\dagger)$ C. tekelili (E.I.Vera, 2012) comb. nov. [Early Cretaceous: West Antarctica]

1606 - $\dagger$ C. wangii (N.Tian \& Y.D.Wang, 2014b) comb. nov. [Middle Jurassic: Liaoning, China]

1607 • $(\dagger)$ C. wehrii (C.N.Mill., 1982) comb. nov. [Miocene: Washington, USA]

1608 References. Bomfleur et al. (2015), Bower (1926), Cheng (2011), Cheng \& Li (2007), Cheng et 1609 al. (2007), Hewitson (1962), Kidston \& Gwynne-Vaughan (1907), Miller (1967, 1971, 1982), 
1610 Schopf (1978), Stockey \& Smith (2000), Tian et al. (2014a,b), Tidwell et al. (1991), Vera

1611 (2012), Zhang \& Zheng (1991).

\section{2.2.3.2.2 Genus Osmundastrum C.Presl, 1847}

1613 Diagnostic stem characters. Stem core a primarily parenchymatous pith. Stelar xylem siphon

1614 thin and with prominent leaf gaps. Leaf protoxylem poles initiating in mesarch position in stele,

1615 becoming endarch in stele, first bifurcating in outermost cortex or outside the stem. Cortex of

1616 stems and stipes two-layered, differentiated into inner, primarily parenchymatous cylinder and

1617 outer sclerenchymatous cylinder; outer stem cortex homogeneous, thicker than inner stem cortex.

1618 Stipes with a pair of stipular wings commonly containing strands of thick-walled fibers of

1619 various shapes and sizes; stipe bundle with incurved tips (i.e., more or less horseshoe-shaped).

1620 Stipe sclerenchyma ring heterogeneous with an abaxial arch or mass and two opposite, separate

1621 or thinly connected lateral masses of particularly thick-walled fibres.

1622 Status. Holophyletic; extant with fossil representatives.

1623 Known geochronologic range. Triassic to present.

1624 Comments. The recently described Osmunda pulchella Bomfleur, G.Grimm \& McLoughlin

1625 from the Lower Jurassic of Sweden is sufficiently similar to extant and other fossil

1626 Osmundastrum species to warrant assignment to this genus (Bomfleur et al., 2015; see also

1627 Grimm et al., 2015; Fig. 16), even though it lacks the fibre patch adaxial to each leaf trace that is

1628 characteristic of the other species. We also include another pre-Cretaceous species in

1629 Osmundastrum, $O$. indentatum, which is less derived and, as a consequence, overall more similar

1630 to the basic type within Osmundinae as seen in members of Claytosmunda and Osmunda (to

1631 some degree), and accordingly placed in the neighbour nets. 
more distinct from extant $O$. cinnamomeum than other specimens that have been included in the

1634 latter species, thus we accept is as a separate species. Whether (some) fossil O. cinnamomeum

1635 are better treated as distinct species requires a better understanding of the extant diversity in this

1636 species. We note that the diversity evident in the fossils is as high or higher than between species

1637 of other (extinct and extant) genera (see also Supplemental File S3); a O. cinnamomeum-only

1638 clade would receive low or diminishing support. Overall these modern-type Osmundastrum

1639 rhizomes (O. cinnamomeum, O. precinnamomeum) nevertheless form a coherent group distinct

1640 from other Osmundinae or Osmundoideae; a corresponding clade would receive moderate

1641 support under ML and LS (low under MP; Table 3). Osmundastrum pulchellum (Bomfleur,

1642 G.Grimm \& McLoughlin) comb. nov. from the Lower Jurassic of Sweden is a probable

1643 precursor of modern Osmundastrum, which ranges from the Late Cretaceous onwards (Bomfleur

1644 et al., 2015). Hence, we include it in this holophyletic genus, even though it lacks the fibre patch

1645 adaxial to each leaf trace that is characteristic of the modern members. The intermediate,

1646 bridging nature of this fossil is also apparent in the neighbour nets provided here, where it

1647 consistently occupies a position between modern Osmundastrum and early representatives with

1648 putatively primitive axis anatomy as seen in early Claytosmunda. This placement underscores its

1649 great similarity to its more derived congeners $(\mathrm{MD} \geq 0.08)$ and to early members of the

1650 Claytosmunda-Osmunda(-Plenasium) lineage (MD $\geq 0.10)$. If forced into a tree, O. pulchellum

1651 would be placed close to modern Osmundastrum (Table 3; see also BS support networks in the

1652 Supplemental Data Archive), as expected for an early member of this lineage.

1653 Molecular dating using the frond fossil record confirms a Triassic split between

1654 Osmundastrum and the remainder of the Osmundinae (Bomfleur et al., 2015; Grimm et al., 
1655 2015). Triassic Osmundaceae fossils include Osmundinae rhizomes with a heterogenous

1656 sclerenchyma ring in the leaf traces, usually exhibiting the pattern typical of many Jurassic

1657 Osmundinae and the extant Claytosmunda claytoniana. An exception is Australosmunda

1658 indentata (Hill et al., 1989), which has the typical Osmundastrum configuration. In other aspects

1659 (e.g., stele dissection), this species is most similar to the Jurassic Claytosmunda embreii, and to a

1660 lesser degree, $C$. sinica and C. preosmunda; corresponding clades would receive low but

1661 consistent support based on our matrices (Table 3). Given the high conservatism and diagnostic

1662 value of the organisation of the heterogenous sclerenchyma ring in all extant members of

1663 Osmundaceae (Osmundeae; see, e.g., Hewitson, 1962; Miller, 1967, 1971; Bomfleur et al., 2015;

1664 this study), we nevertheless regard Millerocaulis indentata as an early member of the

1665 Osmundastrum lineage. We consider its association with early Claytosmunda spp. in the graphs

1666 to be a methodological artefact due to the dominance of shared primitive (such as a nearly

1667 imperforate stele and commonly mesarch basal leaf traces) or generally homoplastic features

1668 encoded in our matrix among the earliest members of both lineages within Osmundinae

1669 (compare also the neighbour nets with potential tree, BS-best supported topologies). This

1670 example cautions that classification of fossil taxa should always consider the actual traits shared

1671 or not by two taxa resolved as potential sisters in trees or grouped in networks. A further hint to

1672 the existence of two already differentiated, modern lineages in the Triassic is the higher diversity

1673 between the Triassic Osmundinae species ( $\mathrm{MD}=0.14$ between the purported sister species

1674 Osmundastrum indentatum and Claytosmunda embreii; $\mathrm{MD}=0.42$ between $C$. beardmorensis

1675 and Osmundastrum indentatum) in comparison to the situation from the Jurassic onwards (e.g.,

$1676 \mathrm{MD} \geq 0.08$ vs. $\geq 0.10$ between Osmundastrum pulchellum and other Osmundastrum or

1677 Claytosmunda/Osmunda). 


\section{Included species:}

1679

1680

1681

1682

1683

1684

1685

1686

1687

1688

1689

1690

- O. cinnamomeum (L.) C.Presl, 1847 [Extant: East Asia, eastern North America to eastern South America; Miocene: Hokkaido, Japan and Washington, USA; Cretaceous: Alberta, Canada]

- $(\dagger)$ O. precinnamomeum (C.N.Mill., 1967), comb. nov. [Paleocene: North Dakota, USA]

- $(\dagger)$ O. pulchellum (Bomfleur, G.Grimm \& McLoughlin, 2015) comb. nov. [Early Jurassic: Sweden]

- $(\dagger)$ O. indentatum (R.S.Hill, S.M.Forsyth \& F.Green, 1989) comb. nov. [Triassic: Tasmania, Australia]

References. Bomfleur et al. (2014, 2015), Bower (1926), Faull (1901, 1910), Grimm et al. (2015), Gwynne-Vaughan (1911), Hewitson (1962), Hill et al. (1989), Kidston \& GwynneVaughan (1907), Matsumoto \& Nishida (2003), Miller (1967, 1971), Serbet \& Rothwell (1999), Wardlaw (1946).

1691

\subsection{Osmunda L., 1753}

1692 Diagnostic axis characters. Stem core a primarily parenchymatous pith. Stelar xylem siphon 1693 thin and with prominent leaf gaps. Leaf protoxylem poles initiating in mesarch position in stele, 1694 becoming endarch in stele or rarely in cortex; leaf trace either arising with single protoxylem 1695 strand that bifurcates in inner or outer cortex or rarely arising from stele already with two 1696 protoxylem strands. Cortex of stems and stipes two-layered, differentiated into inner

1697 parenchymatous cylinder and outer sclerenchymatous cylinder; outer stem cortex homogeneous, 1698 thicker than inner stem cortex. Stipes with a pair of stipular wings commonly containing strands 1699 of thick-walled fibers of various shapes and sizes; stipe bundle with incurved tips (i.e., more or 
1700 less horseshoe-shaped). Stipe sclerenchyma ring heterogeneous developing two opposite lateral

1701 masses that may extend and conjoin into an adaxial arch of particularly thick-walled fibers.

1702 Status. Holophyletic; extant with fossil representatives.

1703 Known geochronologic range. Paleocene to present.

1704 Comments. Based only on axis anatomy, it is difficult to distinguish clearly between Osmunda

1705 and the paraphyletic Claytosmunda, which comprises stem group members of the Osmundinae

1706 and members of the actual lineage leading to the extant $C$. claytoniana (note the placement of the

1707 extant $O$. lancea in neighbour-nets). According to a recent molecular dating that makes use of

1708 the entire rhizome and frond fossil record of modern Osmundaceae, the C. claytoniana-lineage

1709 diverged from the Osmunda-Plenasium lineage sometime in the Jurassic (Bomfleur et al., 2015;

1710 Grimm et al., 2015), with Osmunda and Plenasium separating in the Cretaceous. Thus, Jurassic

1711 and younger Osmundinae fossils likely represent members of either the C. claytoniana lineage or

1712 the Osmunda-Plenasium lineage. However, Palaeogene fossils (O. oregonensis, O. pluma) still

1713 appear intermediate between extant members of Osmunda and Claytosmunda in their

1714 development of leaf-trace protoxylem and development of fibre masses in the sclerenchyma ring.

1715 This is also well reflected by their intermediate position in the neighbour nets. Some fossil axes

1716 show the modern Osmunda feature of the leaf-trace protoxylem dividing already in the inner

1717 cortex, but also the retention of just two separate lateral fibre masses in the sclerenchyma ring

1718 instead of an adaxial arch, as is typical of Claytosmunda. Hence, we restrict Osmunda to only

1719 those species that have the adaxial arch in the sclerenchyma ring, and retain other early potential

1720 members of the Osmunda-lineage in Claytosmunda until more explicit phylogenetic hypotheses

1721 can be presented.

1722 Included species: 
1723

1724

1725

1726

1727

1728

1729

1730

1731

1732

1733

1734

1735

1736

1737

1738

1739

1740

1741

1742

1743 heterogeneous, differentiating distally into a thin band of particularly thick-walled fibres forming

1744 the outer margin of the sclerenchyma ring. 
1745 Status. Holophyletic; extant with fossil representatives

1746 Known geochronologic range. Early Cretaceous to present.

1747 Comments. Plenasium species differ from all remaining Osmundoideae in that their leaf-traces

1748 originate typically from two independent protoxylem poles in two adjacent xylem segments.

1749 2.2.3.2.4.1 (†) Plenasium subgenus Aurealcaulis (Tidwell \&

1750 L.R.Parker), 1987, comb. et stat. nov.

1751 Diagnostic characters. Stems arborescent, reaching great size; steles highly perforate and

1752 dissected, comparatively thick (up to ca 25 tracheids in radial thickness); leaf traces usually

1753 originating from two independent protoxylem poles from two adjacent stelar xylem segments

1754 [similar to Plenasium], departing from stele usually in the form of two separate bundles that fuse

1755 into a single C-shaped strand in their course through the cortex. Cortex of stems and stipes two-

1756 layered, differentiated into inner parenchymatous cylinder and outer sclerenchymatous cylinder;

1757 outer stem cortex homogeneous, thicker than inner stem cortex. Stipes with a pair of stipular

1758 wings typically containing a single or numerous distinct masses, commonly in elongate shape or

1759 arrangement; stipe bundle with incurved tips (i.e., more or less horseshoe-shaped). Stipe

1760 sclerenchyma ring heterogeneous, differentiating distally into a thin band of particularly thick-

1761 walled fibres forming the outer margin of the sclerenchyma ring.

1762 Status. Possibly ancestral (paraphyletic per definition) to subgenus Plenasium; extinct.

1763 Known geochronologic range. Early Cretaceous to ?mid-Eocene.

1764 Comments. Since Aurealcaulis was established (Tidwell \& Parker, 1987), it has been considered

1765 fundamentally different from other Osmundaceae because of its allegedly exarch leaf-trace

1766 protoxylem and its leaf traces arising in the form of two separate masses. The first feature is 
1767 plainly a misidentification: the putative 'protoxylem cells' that would render trace formation 1768 exarch (see arrow in fig. 17 of Tidwell \& Parker, 1987) are only smaller metaxylem cells at the 1769 stele periphery, just as in the stelar xylem of any other osmundaceous fern. The center left of the 1770 same figure shows a stelar xylem segment with an actual protoxylem pole in mesarch position.

1771 The second feature is that a given leaf trace usually arises in the form of two separate 1772 segments - each with one inward-facing protoxylem pole - that fuse into one C-shaped segment 1773 inside the cortex only at some distance from the stele. This seemingly unique feature, however, is 1774 merely an extreme form of the mode of leaf-trace formation represented in Plenasium. In extant 1775 Plenasium species, the tips of the two meristele segments first fuse with each other and then 1776 separate from the stele in the form of a single, deeply C-shaped trace (e.g., Miller, 1971). The 1777 Eocene Plenasium arnoldii and P. dowkeri are somewhat intermediate in that curvature of the 1778 basal leaf trace is so strong and the thickness of the strand so uneven that they adopt a curved 1779 dumbbell shape, with two thick xylem segments connected only by a thin band of tracheids (see, 1780 e.g., Chandler, 1965: figs 3, 4, 6, 7, 17; Arnold, 1952: figs 13, 14, 16). In fact, a few leaf traces 1781 appear to depart from the stele in the typical Aurealcaulis manner, i.e., in the form of two 1782 completely separate segments (see, e.g., Chandler, 1965: figs 6, 7). Conversely, basal leaf traces 1783 of Aurealcaulis arise sporadically in the form of a deeply indented, but nonetheless intact C1784 shaped strand just like those typical of $P$. chandleri and $P$. arnoldii. This type of leaf-trace 1785 formation is indeed common enough that Tidwell \& Parker referred to it as 'the other type of 1786 trace formation' in the original description of Aurealcaulis (Tidwell \& Parker, 1987: 807).

1787 Hence, the supposedly unique mode of trace formation in Aurealcaulis is one end member of a 1788 spectrum that also encompasses forms typical of extinct and, to a lesser degree, extant Plenasium 1789 species. 
Another problematic diagnostic feature relates to the heterogeneity of cells in the stipe

1791 sclerenchyma ring — the distinctive feature of all 'modern' Osmundoideae. Most recent

1792 taxonomic treatments of fossil Osmundaceae have adopted characters from the original

1793 publication without critical appraisal: e.g., that the sclerotic ring in Aurealcaulis petioles were

1794 homogeneous (Tidwell \& Parker, 1987: 805; see, e.g., Tian et al., 2008; Wang et al., 2014a, b).

1795 Cheng and Li (2007), however, already noted that the stipe sclerenchyma ring of Aurealcaulis

1796 has a heterogeneous composition. Tidwell and Parker (1987: p. 809) wrote in their original

1797 description 'the cells comprising this ring are generally uniform in size (50-70 $\mu \mathrm{m}$ in diam.) and

1798 wall thickness (10-25 $\mu \mathrm{m})$. However, a layer of fibers near the edge of the sclerotic ring is much

1799 thicker-walled and appears to be more resistant to decay than the remainder of the ring'

1800 (Tidwell \& Parker, 1987: p. 809). We consider this to represent just different phraseology for

1801 describing the type of heterogeneous sclerenchyma ring that occurs in Plenasium: 'While the

1802 sclerenchyma ring of the petiole base appears homogeneous in species of Plenasium, there is a

1803 very thin abaxial arch of thick-walled fibers visible in transverse sections near the stem. In

1804 sections more distant from the stem, the ring is completely surrounded by a narrow layer of these

1805 cells, and this situation persists throughout the stipular region' (Miller, 1967: p. 181)—or,

1806 alternatively: 'thick-walled fibers in sclerenchyma ring thin near attachment to stem extending to

1807 surround ring as a narrow band in lower one-third of stipular region' (Miller, 1971: p. 131).

1808 Finally, Aurealcaulis has been described to differ from all other Osmundaceae in that its

1809 roots arise directly from the trace and not from the stele (Tidwell \& Parker, 1987: p. 811).

1810 However, this is the regular mode of root formation in other Osmundaceae (e.g., Bower, 1926;

1811 Hewitson, 1962; Miller, 1967, 1971). 
With these supposed differences revised, we identify Aurealcaulis as being: (1) a typical

1813 member of Osmundaceae with mesarch protoxylem in the stem and endarch protoxylem in the

1814 leaf traces; (2) a member of Osmundeae (modern Osmundoideae) with a heterogeneous stipe

1815 sclerenchyma ring similar to those of Todea, Leptopteris, and Plenasium; (3) an extinct member

1816 of Osmundinae owing to its homogeneous outer cortex (unlike Todeinae; Tidwell \& Medlyn

1817 1991); and (4) a close relative and possible ancestor of extant species of Plenasium owing to

1818 their peculiar similarities of having two protoxylem initials per leaf trace, leaf traces arising in

1819 the form of two separate or thinly connected deeply indented masses, and a similar type of

1820 development of the sclerenchyma ring.

1821 Included species:

1822 - (†) P. bransonii (Tidwell \& Medlyn, 1991) comb. nov. [?Eocene: New Mexico, USA]

1823 - $(\dagger)$ P. burgii (Tidwell \& J.E.Skog, 2002) comb. nov. [Early Cretaceous: Nebraska, USA]

1824 - $(\dagger)$ P. crossii (Tidwell \& L.R.Parker, 1987) comb. nov. [Paleocene: Wyoming, USA]

1825 - (†) P. dakotense (Tidwell \& J.E.Skog, 2002) comb. nov. [Early Cretaceous: South Dakota,

$1826 \quad$ USA]

1827 • $\dagger$ P. Poorei (Tidwell \& Medlyn, 1991) comb. nov. [?Eocene: New Mexico, USA]

1828 - $(\dagger)$ P. nebraskense (Tidwell \& J.E.Skog, 2002) comb. nov. [Early Cretaceous: Nebraska,

$1829 \quad$ USA]

1830 References. Arnold (1945, 1952), Chandler (1965), Hewitson (1962), Miller (1967, 1971),

1831 Tidwell \& Medlyn (1991), Tidwell \& Parker (1987), Tidwell \& Skog (2002). 
1832

1833

1834

1835

1836

1837

1838

1839

1840

1841

1842

1843 sclerenchyma ring.

1844 Status. Holophyletic; extant with fossil representatives

1845 Known geochronologic range. Paleocene to present.

1846

1847

1848

1849

1850

1851

1852

1853

\subsection{Plenasium subgenus Plenasium} Included species: - P. javanicum (Blume) C.Presl, 1848 [Extant: Southeast Asia] - P. vachelii C.Pres1, 1848 [Extant: Southeast Asia] $(1967,1971)$.

Diagnostic stem characters. Stem core a primarily parenchymatous pith. Stelar xylem siphon thin (usually up to $c a 15$ tracheids in radial thickness) and with prominent leaf gaps; leaf protoxylem poles initiating in mesarch position in stele, becoming endarch in stele; leaf trace strongly curved adaxially upon departure from stele, usually arising with two protoxylem strands from two adjacent stelar xylem segments. Cortex of stems and stipes two-layered, differentiated into inner parenchymatous cylinder and outer sclerenchymatous cylinder; outer stem cortex homogeneous, thicker than inner stem cortex. Stipes with a pair of stipular wings typically containing numerous, small scattered strands of thick-walled fibers; stipe bundle with incurved tips (i.e., more or less horseshoe-shaped). Stipe sclerenchyma ring heterogeneous, differentiating distally into a thin band of particularly thick-walled fibres forming the outer margin of the

- P. banksiifolium C.Presl) C.Presl, 1836 [Extant: East and Southeast Asia] - P. bromeliifolium (C.Presl) C.Presl, 1836 [Extant: East and Southeast Asia] - (†) P. arnoldii (C.N.Mill., 1967), comb. nov. [Paleocene: North Dakota, USA] References. Chandler (1965), Hewitson (1962), Kidston \& Gwynne-Vaughan (1907), Miller 
1854 2.2.3.2.4.? Plenasium subgenus indet.

1855 Comments. Plenasium dowkeri and P. chandleri from the Palaeogene of North America and

1856 Europe occupy intermediate positions between species of subgenus Plenasium and species of

1857 subgenus Aureacaulis in the neighbour nets (Figs 11, 13, 15, 16). Information on axis anatomy is

1858 at present inadequate to determine whether these two species are better assigned to subgenus

1859 Plenasium or subgenus Aurealcaulis. Therefore, we retain these species simply as Plenasium

1860 subgenus indet.

1861 • $\dagger$ P. Phandleri (Arnold, 1952) comb. nov. [Eocene: Oregon, USA]

1862 • (†) P. dowkeri (Carruth., 1870) comb. nov. [Paleocene: North Dakota, USA; UK]

1863 2.? Family Osmundaceae, subfamily unknown

1864 2.?.1 (†) Genus Osmundacaulis C.N.Mill., 1967 emend. Tidwell, 1986

1865 (Figure 17)

1866 Diagnostic characters. Axes usually arborescent or erect, rarely rhizomatous. Cortex of stems

1867 and stipes two-layered, differentiated into inner, primarily parenchymatous cylinder and outer

1868 sclerenchymatous cylinder; inner stem cortex thicker than outer stem cortex. Peripheral xylem

1869 siphon with prominent leaf gaps, very thick (typically $>30$ tracheids in radial thickness),

1870 commonly highly perforated [except $O$. lemonii, O. nerii, O. tidwellii and O. whittlesii]; phloem

1871 external and internal and sporadically connecting through leaf gaps (i.e., dictyostelic). Leaf-trace

1872 protoxylem initially single and in mesarch position in stele, in most cases dividing repeatedly in

1873 stele and inner cortex [except O. bamfordae]; leaf trace strongly curved already upon departure 
1874 from stele. Stipes with a pair of stipular wings; stipe bundle with incurved tips (i.e., horseshoe1875 shaped).

1876 Status. Putatively holophyletic, extinct.

1877 Known geochronologic range. Jurassic to Cretaceous.

1878 Comments. Osmundacaulis is clearly distinct from other Osmundaceae in having an inner 1879 cortex that is thicker than the outer cortex, in having very thick and typically highly perforated 1880 stelar metaxylem cylinders, and in having leaf traces that are already strongly curved at the point 1881 of departure from the stele. These features served to distinguish first the species Osmundites 1882 skidegatensis Penh. (see Kidston \& Gwynne-Vaughan, 1908) and later the 'Osmundacaulis 1883 skidegatensis group' (Miller, 1971) that subsequently formed Osmundacaulis Miller emend. 1884 Tidwell as currently understood. Osmundacaulis contains a disparate array of morphologically 1885 distinct species that, analogous to Millerocaulis, are transitional from having highly perforated 1886 steles (e.g., O. skidegatensis) to only a few (e.g., O. nerii, O. tidwellii), or no perforations at all 1887 (O. lemonii).

1888 Included species:

$1889 \bullet(\dagger)$ O. andrewii Tidwell \& Pigg, 1993 [?Early Jurassic: Tasmania, Australia]

1890 - $\dagger$ ) O. atherstonei (Schelpe) C.N.Mill., 1971 [Early Cretaceous: South Africa]

1891 • $\dagger$ O. Oamfordae R.Herbst, 2015 [Early Cretaceous: South Africa]

1892 • $(\dagger)$ O. griggsii Tidwell \& Pigg, 1993 [Early Jurassic: Tasmania, Australia]

1893 • $($ †) O. hoskingii R.E.Gould, 1973 [Middle Jurassic: Queensland, Australia]

1894 • (†) O. janae Tidwell \& Pigg, 1993 [Early Jurassic: Tasmania, Australia]

1895 • (†) O. jonesii Tidwell, 1987 [Early Jurassic: Tasmania, Australia]

1896 • (†) O. lemonii Tidwell, 1990 [Late Jurassic: Utah, USA] 
1897

1898

1899

1900

1901

1902

1903

1904

1905

1906

1907

1908

1909

1910

1911

1912

1913

1914

1915

1916

1917 1918

- (†) O. natalensis (Schelpe) C.N.Mill., 1971 [Early Cretaceous: South Africa]

- (†) O. nerii Tidwell \& Ross Jones, 1987 [Early Jurassic: Tasmania, Australia]

- (†) O. pruchnickii Tidwell \& Pigg, 1993 [Early Jurassic: Tasmania, Australia]

- (†) O. richmondii Tidwell \& Pigg, 1993 [Early Jurassic: Tasmania, Australia]

- (†) O. skidegatensis (Penh.) C.N.Mill., 1967 [Early Cretaceous: British Columbia, Canada]

- $(\dagger)$ O. tasmanensis Tidwell \& Pigg, 1993 [Early Jurassic: Tasmania, Australia]

- (†) O. tehuelchensis R.Herbst, 2003 [Middle Jurassic: Argentina]

- $(\dagger)$ O. tidwellii R.Herbst, 2015 [Early Cretaceous: South Africa]

- (†) O. whittlesii McKenzie A.Smith, G.W.Rothwell et al., 2015 [Early Cretaceous: British Columbia, Canada]

- (†) O. zululandensis R.Herbst, 2015 [Early Cretaceous: South Africa]

References. Bower (1926), Gould (1973), Herbst (2003, 2008, 2015), Kidston \& GwynneVaughan (1907), Miller (1971), Penhallow (1902a,b), Schelpe (1955, 1956), Smith et al. (2015), Tidwell (1986, 1987, 1990, 2002), Tidwell \& Jones (1987), Tidwell \& Pigg (1993).

\section{2.?.2 (†) Genus Shuichengella Z.M.Li, 1993}

Diagnostic characters. Axes large, erect to arborescent. Cortex of stems and stipes two-layered, differentiated into inner, primarily parenchymatous cylinder and outer sclerenchymatous cylinder; inner stem cortex much thicker than outer stem cortex, containing numerous (up to 60) leaf traces in a given transverse section. Peripheral xylem siphon with sporadic narrow, complete leaf gaps, thin (typically ca 10 cells in radial thickness). Leaf trace strongly curved upon departure from stele, containing three protoxylem clusters in inner cortex.

Status. Monotypic, extinct. 
1919 Known geochronologic range. Late Permian.

1920 Comments. The precise systematic affinities of Shuichengella primitiva within Osmundaceae

1921 are unknown. It is notable, however, that the genus shares some rather unusual characters with

1922 Osmundacaulis, e.g., an inner cortex that is much thicker than the outer cortex, and the strong

1923 curvature and multiple protoxylem clusters of leaf traces already differentiated upon departure

1924 from the the stele. Li (1993) instituted the subfamily Shuichengelloideae for the monotypic

1925 genus; however, considering that, for instance, important information on stipe anatomy is lacking

1926 (see Tidwell \& Ash 1994) and that insufficient comparison can be made with other taxa, we

1927 consider Shuichengella to be too poorly known to warrant erection of a separate subfamily.

1928 Included species:

1929 • (†) S. primitiva (Z.M.Li) Z.M.Li, 1993 [Late Permian: Guizhou, China]

1930 References. Li (1983, 1993), Tidwell \& Ash (1994).

\section{$19312 . ? .3(\dagger)$ Genus Anomorrhoea Eichw., 1860}

1932 Status. Nomen dubium, extinct.

1933 Known geochronologic range. Late Permian.

1934 Comments. The holotype is a fragment of the mantle of roots and stipe bases with a small

1935 portion of outer cortex attached; stele, inner cortex, and most of the outer cortex is missing. It is,

1936 thus, too fragmentary to be identified with certainty (Kidston \& Gwynne-Vaughan, 1909;

1937 Zalessky, 1927; Miller, 1971). The sclerotic outer cortex and prominent stipular wings indicate

1938 affinities with Osmundaceae, but the lack of information on the stem-core composition makes it

1939 impossible to determine whether, for example, the genus belongs to Osmundoideae or to 
1940 Thamnopteroideae. We propose that use of the name should be abandoned until better and more

1941 completely preserved material enables more detailed comparison.

1942 Included species:

1943 • (†) A. fischeri Eichw., 1860 [Late Permian: Russia; here considered Osmundaceae gen.

1944 indet.]

1945 References. Kidston \& Gwynne-Vaughan (1909), Zalessky (1927), Miller (1971).

1946 2.2.4 (†) Genus Bathypteris Eichw., 1860

1947 Diagnostic characters. Stems forming large, arborescent trunks. Stem core consisting of

1948 tracheids with scalariform thickenings. Peripheral metaxylem siphon entire and imperforate.

1949 Cortex of stems and stipes two-layered, differentiated into inner parenchymatous cylinder and

1950 outer sclerenchymatous cylinder. Leaf-trace protoxylem single. Stipes lacking stipular wings but

1951 bearing multicellular spines; stipe bundle with incurved tips (i.e., more or less horseshoe-

1952 shaped), surrounded by sclerotic cells that form a narrow lining band. Sclerenchyma ring in stipe

1953 base circular to elliptic in cross-section, homogenous.

1954 Status. Monotypic, extinct.

1955 Known geochronologic range. Late Permian.

1956 Comments. The affinities of Bathypteris cannot be determined precisely; it has a two-layered

1957 cortex and horseshoe-shaped stipe bundle typical of Osmundaceae, but its petiole surfaces bear

1958 multicellular spines instead of the characteristic stipular wings — a feature otherwise known only

1959 from Itopsidema among Osmundales (Daugherty, 1960).

1960 Included species:

1961 • $(\dagger)$ B. rhomboidalis (S.Kutorga) Eichw., 1860 [Late Permian: Russia] 
1962 References. Kidston \& Gwynne-Vaughan (1909), Zalessky (1927), Miller (1971).

\section{Conclusion and outlook}

1964 This study provides a comprehensive comparative dataset and the methodological tool-kit to 1965 describe, identify, and classify fossil osmundalean axes. A phylogenetic framework assigns 1966 explicit biological meaning to the names of fossil and extant taxa. The design of our character 1967 matrix is optimized for these purposes. Information on the anatomy of forthcoming finds of 1968 fossil osmundalean axes can easily be incorporated into the matrix in order to facilitate 1969 systematic placement, comparisons, and character analysis. We propose natural groups that can 1970 be identified based on diagnostic character suites, and we aim to reconcile the extensive fossil 1971 record of the group in the form of anatomically preserved axes with modern phylogenies and 1972 systematic treatments of extant taxa based on molecular data. In light of the wealth of 1973 information about the axis anatomy in extant and fossil Osmundales, the use of artificial form1974 genera of osmundalean axes is, in our opinion, no longer needed; overall, axis anatomy has 1975 proven so informative for the systematic interpretation of fossil Osmundales that in case an 1976 anatomically preserved axis cannot be identified with certainty, it should be described in open 1977 nomenclature instead of being formally described. With the artifice of accepting also 1978 paraphyletic taxa as valid taxonomic units, we expect our systematic framework to be 1979 particularly stable and widely applicable, yet adaptable in case new data warrant erection of new 1980 groups. Furthermore, we hope to have set a new basis for in-depth analyses of evolutionary 1981 trends in Osmundales. The many homoplasious characters in our matrix make it difficult to infer 1982 explicit scenarios for the evolution of the order; a first necessary step will, therefore, be to assess 1983 which characters or character suites are compatible with the molecular tree. Ideally, this will 
1984 make it possible to estimate probabilities for character changes, which can then be included in

1985 subsequent tree inferences (e.g. as character weights in a ML or Bayesian framework). Total

1986 evidence (TE) analysis would benefit from using approaches that treat fossils not as terminal

1987 taxa, but place them according to their age (Ronquist et al. 2012, but see the result of TE dating

1988 for the modern Osmundoideae lineage provided in the supplement to Grimm et al., 2015). Much

1989 of the diversity and disparity of osmundalean axes is, however, concentrated in lineages with no

1990 extant representatives, and the evolutionary history of Osmundales spans at least $255 \mathrm{Ma}$. Our

1991 revision indicates that various lineages of Osmundales gave rise to similar adaptations during

1992 different time intervals ('temporal convergences'). Thus, it is important to assess diversity and

1993 phylogenetic relationships independently for each time slice, and compare the results to the

1994 preceding or subsequent time slice. A promising experiment may be to add also hypothetical

1995 ancestors of the extant genera placed in the corresponding time period, defined by a set of

1996 characters reconstructed using probabilistic ancestral state reconstruction methods (e.g.

1997 Felsenstein 2012; Revell 2012). A sound evolutionary hypothesis for Osmundales should include

1998 horizontal contemporaneous diversity patterns as well as vertical (along phylogenetic lineages)

1999 evolutionary trends.

2000 Acknowledgements

2001 We thank the editor William DiMichele (Washington, DC) and two anonymous reviewers

2002 for detailed and constructive criticism on an earlier version of this manuscript; Harald

2003 Schneider (London/Xishuangbanna) for helpful discussion on the recently revised

2004 classification of modern Osmundaceae (PPG I, 2016); Weston Testo (Burlington) for

2005 providing complete documentation of the phylogenetic analyses in Testo \& Sundue (2016); 
2006 and Ignacio H. Escapa (Trelew), Juan Garcia Massini (La Rioja), Ning Tian (Shenyang),

2007 Ezequiel I. Vera (Buenos Aires), and Yongdong Wang (Nanjing) for kind help in obtaining

2008 literature.

2009 Appendix A: Formal taxonomic treatment of nomenclatural novelties

2010 Guaireaceae subfam. Itopsidemoideae subfam. nov.

2011 Name-bringing genus. Itopsidema Daugherty (in American Journal of Botany 47: 775. 1960).

2012 Diagnosis. Stems radially symmetrical with spiral phyllotaxis. Stem core a parenchymatic pith

2013 with variable amounts of interspersed sclereids and tracheids; stele with a distinct peripheral

2014 metaxylem siphon lacking discrete leaf gaps and consisting of a spongy admixture of metaxylem

2015 and more-or-less diffusely interspersed patches of parenchyma. Stem cortex primarily

2016 parenchymatous and not differentiated into distinct layers; stipe without stipular wings and

2017 sclerenchyma ring; stipe vascular bundle with recurved tips (i.e., more or less inverse-omega-

2018 shaped). Roots commonly arising from abaxial side of leaf trace within the stem cortex.

2019 Tribus Osmundeae subtribus Osmundinae subtrib. nov.

2020 Name-bringing genus. Osmunda L. (in Species Plantarum 2: 1063. 1753)

2021 Diagnosis. Stem core a primarily parenchymatous pith. Stelar xylem siphon comparatively thin

2022 and with prominent leaf gaps. Leaf protoxylem poles initiating in mesarch position in stele,

2023 becoming endarch in stele or (rarely) in cortex. Cortex of stems and stipes two-layered, 
2024 differentiated into inner, primarily parenchymatous cylinder and outer sclerenchymatous

2025 cylinder; outer stem cortex homogeneous, thicker than inner stem cortex. Stipes with a pair of

2026 stipular wings commonly containing strands of thick-walled fibers of various shapes and sizes;

2027 stipe bundle with incurved tips (i.e., more or less horseshoe-shaped). Stipe sclerenchyma ring

2028 heterogeneous: differentiation typically initiating in the stipe base with the formation of an

2029 abaxial arch of particularly thick-walled fibres.

2030 Tribus Osmundeae subtribus Todeinae subtrib. nov.

2031 Name-bringing genus. Todea Willd. ex Bernh. (in Schraders Jahrbuch der Botanik 1800(2):

2032 126. 1801)

2033 Diagnosis. Stem core a primarily parenchymatous pith. Stelar xylem siphon comparatively thin

2034 and with prominent leaf gaps. Leaf protoxylem poles initiating in mesarch position in stele,

2035 becoming endarch in stele or (rarely) in cortex, first bifurcating as leaf-trace departs from stem.

2036 Cortex of stems and stipes two-layered, differentiated into inner, primarily parenchymatous

2037 cylinder and outer sclerenchymatous cylinder; inner stem cortex usually thinner than outer stem

2038 cortex; outer stem cortex heterogeneous, with a distinct ring of fibres surrounding each leaf trace.

2039 Stipes with a pair of stipular wings; stipe bundle with incurved tips (i.e., more or less horseshoe-

2040 shaped); stipe sclerenchyma ring heterogeneous, differentiating upwards into a thin band of

2041 particularly thick-walled fibres forming the outer margin of the sclerenchyma ring. 
2042 Millerocaulis tuhajkulensis (Pryn. in Gorskii, 1944 ex Pryn., 1974) comb. nov.

2043 Basionym. Osmundites tuhajkulensis Pryn. in Gorskii (in 'Geology of the USSR' [in Russian]

2044 XII: 252. 1944; nomen nudum) ex Pryn. (in 'Proceedings of the All-Union Scientific Research

2045 Geological Institute’ [in Russian] 182: 254. 1974)

2046 Synonym. Osmundites jelkinensis Pryn. in Gorskii (in 'Geology of the USSR' [in Russian] XII:

2047 252. 1944; nomen nudum).

2048 Comments. Presumably due to its publication in Russian, the species has been largely

2049 overlooked in the international literature (but see Gould, 1970).

2050 Claytosmunda beardmorensis (J.M.Schopf, 1978) comb. nov.

2051 Basionym. Osmundacaulis beardmorensis J.M.Schopf (in Canadian Journal of Botany 56: 3034.

2052 1978)

2053 Synonyms.

2054 Millerocaulis beardmorensis (J.M.Schopf) Tidwell (in SIDA 11: 402. 1986)

2055 Ashicaulis beardmorensis (J.M.Schopf) Tidwell (in SIDA 16: 256. 1994)

2056 Comments. This species is known from large, silicified root mounds from the Middle Triassic

2057 Fremouw Formation of the Transantarctic Mountains (Schopf, 1978). Root growth removed

2058 much of the parenchyma of the rhizomes inside the mounds; therefore, knowledge about the

2059 anatomy, especially of the stipes, is still incomplete. However, those features available

2060 demonstrate very close similarity to extant Claytosmunda claytoniana. This is even more

2061 noteworthy because large, almost complete frond compression fossils identical to modern 
2062 Claytosmunda claytoniana occur also in the Triassic of East Antarctica (Taylor et al. 1990;

2063 Phipps et al. 1998).

2064 One remarkable difference is that leaf traces of $O$. beardmorensis commonly arise with 2065 protoxylem still in mesarch position (Schopf, 1978; Bomfleur, pers. obs. 2012). This feature,

2066 however, also occurs in other species of Osmundoideae and might reflect aberrant development 2067 of an ancestral state.

2068 Claytosmunda chengii nom. nov.

2069 Basionym. Ashicaulis claytoniites Y.-M.Cheng (in Review of Palaeobotany and Palynology 156: $207098.2011)$

2071 Synonyms.

2072 Claytosmunda claytoniites (Y.-M.Cheng, 2011) comb. nov. [to be replaced; a junior homonym 2073 of Claytosmunda claytoniites (C.J.Phipps, T.N.Taylor, E.L.Taylor et al., 1998) comb. nov. 2074 based on (basionym) Osmunda claytoniites C.J.Phipps, T.N.Taylor, E.L.Taylor et al. (in 2075 American Journal of Botany 85: 889. 1998)]

2076 Ashicaulis advencensis Y.-M. Cheng [nomen nudum in Review of Palaeobotany and Palynology 2077 156: 101.2011]

2078 Claytosmunda embreei (Stockey \& S.Y.Sm., 2000) comb. nov.

2079 Basionym. Millerocaulis embreei Stockey \& S.Y.Sm. (in International Journal of Plant Sciences $2080 \quad 161: 160.2000)$ 
2081 Claytosmunda johnstonii (Tidwell, Munzing \& M.R.Banks, 1991) comb. nov.

2082 Basionym. Millerocaulis johnstonii Tidwell, Munzing \& M.R.Banks (in Palaeontographica

2083 Abteilung B 223: 94. 1991)

2084 Synonyms. Ashicaulis johnstonii (Tidwell, Munzing \& M.R.Banks) Tidwell (in SIDA 16: 256. 2085 1994)

2086 Claytosmunda liaoningensis (Wu Zhang \& Shao-Lin Zheng, 1991) comb. nov.

2087 Basionym. Millerocaulis liaoningensis Wu Zhang \& Shao-Lin Zheng (in Acta Palaeontologica 2088 Sinica 30: 717. 1991)

2089 Synonym.

2090 Ashicaulis liaoningensis (Wu Zhang \& Shao-Lin Zheng) Tidwell (in SIDA 16: 256. 1994)

2091 Claytosmunda plumites (N.Tian \& Y.D.Wang, 2014) comb. nov.

2092 Basionym. Ashicaulis plumites N.Tian \& Y.D.Wang (in Journal of Plant Research 127: 210. 2093 2014a)

2094 Claytosmunda preosmunda (Y.M.Cheng, Yu F.Wang \& C.S.Li, 2007) comb. nov.

2095 Basionym. Millerocaulis preosmunda Y.M.Cheng, Yu F. Wang \& C.S.Li (in International 2096 Journal of Plant Sciences 168: 1352. 2007) 
2097 Claytosmunda sinica (Y.M.Cheng \& C.S.Li, 2007) comb. nov.

2098 Basionym. Millerocaulis sinica Y.M.Cheng \& C.S.Li (in Review of Palaeobotany and

2099 Palynology 144: 253. 2007)

2100 Claytosmunda tekelili (E.I.Vera, 2012) comb. nov.

2101 Basionym. Millerocaulis tekelili E.I.Vera (in Alcheringa 36: 37. 2012)

2102 Claytosmunda wangii (N.Tian \& Y.D.Wang, 2014) comb. nov.

2103 Basionym. Ashicaulis wangii N.Tian \& Y.D.Wang (in Science China Earth Sciences 57: 673.

2104 2014b)

2105 Claytosmunda wehrii (C.N.Mill., 1982) comb. nov.

2106 Basionym. Osmunda wehrii C.N.Mill. (in American Journal of Botany 69: 116. 1982)

2107 Osmunda kidstonii (Stopes, 1921) comb. nov.

2108 Basionym. Osmundites kidstonii Stopes (in Annals of Botany 35: 59. 1921)

2109 Synonyms.

2110 Osmundacaulis kidstoni (Stopes) C.N.Mill. ex C.N.Mill. (in Contributions from the Museum of

2111 Paleontology University of Michigan 23: 137. 1971)

2112 Millerocaulis kidstonii (Stopes) Tidwell (in SIDA 11: 403. 1986) 
2113 Ashicaulis kidstonii (Stopes) Tidwell (in SIDA 16: 256. 1994)

2114 Comments. The species is incompletely known; information on the structure of the pith, stele,

2115 and cortex is lacking. However, the anatomy of the stipe bases is so clear and so similar to

2116 modern Osmunda that we have no hesitation in assigning the fossil to this genus.

2117 Osmundastrum indentatum (R.S.Hill, S.M.Forsyth \& F.Green, 1989) comb. nov.

2118 Basionym. Australosmunda indentata R.S.Hill, S.M.Forsyth \& F.Green (in Palaeontology 32:

$2119292.1989)$

2120 Synonyms.

2121 Millerocaulis indentata (R.S.Hill, S.M.Forsyth \& F.Green) Tidwell (in SIDA 16: 255. 1994)

2122 Osmundastrum precinnamomeum (C.N.Mill., 1967) comb. nov.

2123 Basionym. Osmunda precinnamomea C.N.Mill. (in Contributions from the Museum of

2124 Paleontology 21: 171. 1967)

2125 Osmundastrum pulchellum (Bomfleur, G.Grimm \& McLoughlin, 2015) comb. nov.

2126 Basionym. Osmunda pulchella Bomfleur, G.Grimm \& McLoughlin (in BMC Evolutionary

2127 Biology 15: 126. 2015) 
2128 Plenasium subgenus Aurealcaulis stat. et comb. nov.

2129 Original name and status. Genus Aurealcaulis Tidwell \& L.R.Parker (in American Journal of 2130 Botany 74: 805. 1987).

2131 Plenasium (Aurealcaulis) bransonii (Tidwell \& Medlyn, 1991) comb. nov.

2132 Basionym. Aurealcaulis bransonii Tidwell \& Medlyn (in Great Basin Naturalist 51: 331. 1991)

2133 Plenasium (Aurealcaulis) burgii (Tidwell \& J.E.Skog, 2002) comb. nov.

2134 Basionym. Aurealcaulis burgii Tidwell \& J.E.Skog (in Palaeontographica Abteilung B 262: 28. $2135 \quad 2002)$

2136 Plenasium (Aurealcaulis) crossii (Tidwell \& L.R.Parker, 1987) comb. nov.

2137 Synonym. Plenasium (Aurealcaulis) crossii (Tidwell \& L.R.Parker) comb. nov.

2138 Basionym. Aurealcaulis crossii Tidwell \& L.R.Parker (in American Journal of Botany 74: 805. 2139 1987)

2140 Plenasium (Aurealcaulis) dakotense (Tidwell \& J.E.Skog, 2002) comb. nov.

2141 Basionym. Aurealcaulis dakotensis Tidwell \& J.E.Skog (in Palaeontographica Abteilung B 262:

$2142 \quad 32.2002)$ 
2143 Plenasium (Aurealcaulis) moorei (Tidwell \& Medlyn, 1991) comb. nov.

2144 Basionym. Aurealcaulis moorei Tidwell \& Medlyn (in Great Basin Naturalist 51: 326. 1991)

2145 Plenasium (Aurealcaulis) nebraskense (Tidwell \& J.E.Skog, 2002) comb. nov.

2146 Basionym. Aurealcaulis nebraskensis Tidwell \& J.E.Skog (in Palaeontographica Abteilung B $2147 \quad 262: 31.2002)$

2148 Plenasium (Plenasium) arnoldii (C.N.Mill., 1967) comb. nov.

2149 Basionym. Osmunda arnoldii C.N.Mill. (in Contributions from the Museum of Palaeontology 2150 21: 181. 1967)

Plenasium chandleri (Arnold, 1952) comb. nov.

2152 Basionym. Osmundites chandleri Arnold (in Palaeontographica Abteilung B 92: 68. 1952)

2153 Comments. In her detailed treatment of Osmunda dowkeri, M.E.J. Chandler (1965: p. 158)

2154 expressed the opinion that '[...] it seems reasonably certain that Osmundites chandleri should be 2155 transferred to the living Osmunda and to the sub-genus Plenasium within it'. We concur with 2156 this transferal. 
2157 Plenasium dowkeri (Carruth., 1870) comb. nov.

2158 Basionym. Osmundites dowkeri Carruth. (in Quarterly Journal of the Geological Society 26:

$2159352.1870)$

2160 Synonym. Osmunda dowkeri (Carruth.) Chandler (in Bulletin of the British Museum (Natural

2161 History), Geology 10: 142. 1965)

2162

2163 Thamnopteris diploxylon (Kidst. \& Gwynne-Vaughan, 1909) comb. nov.

2164 Basionym. Zalesskya diploxylon Kidst. \& Gwynne-Vaughan (in Transactions of the Royal

2165 Society of Edinburgh 46: 226. 1909)

2166 Thamnopteris gracilis (Eichw., 1860) comb. nov.

2167 Basionym. Chelepteris gracilis Eichw. (in Lethaea Rossica I: 98. 1860)

2168 Synonym. Zalesskya gracilis (Eichw.) Kidst. \& Gwynne-Vaughan (in Transactions of the Royal

2169 Society of Edinburgh 46: 220. 1909)

2170 Thamnopteris javorskii (Zalessky, 1935) comb. nov.

2171 Basionym. Iegosigopteris javorskii Zalessky (in Bulletin de l'Académie des Sciences de

2172 l'URSS: 747. 1935) 
2173 Thamnopteris splendida (Zalessky, 1931) comb. nov.

2174 Basionym. Petcheropteris splendida Zalessky (in Bulletin de l'Académie des Sciences de

2175 l'URSS: 705. 1931b)

2176 Thamnopteris uralica (Zalessky, 1924) comb. nov.

2177 Basionym. Zalesskya uralica Zalessky (in Journal of the Linnean Society, Botany 46: 356. 1924)

2178 Appendix B: Glossary of terms and abbreviations as they are used here

2179 Axis: The most general term applied to the axial organs of Osmundales; includes the stem and its

2180 surrounding mantle of roots and persistent stipe bases; may be, for instance, arborescent (trunk)

2181 or non-arborescent (rhizome).

2182 Complete gap: A leaf gap that completely perforates the stelar xylem siphon; note that gap

2183 formation may be complete even though the complete aspect of the perforation may not be

2184 visible in any single TS, e.g., in cases where gaps are small and transect the siphon obliquely at 2185 an acute angle.

2186 Delayed gap: Mode of formation of a complete leaf gap in which the gap breaks through to the 2187 pith only after the trace has departed from the stele.

2188 Dictyostele: Type of stele with external and internal phloem layers connecting through (at least 2189 some) leaf gaps, thus completely enveloping stelar xylem segments (or groups thereof) in TS of 2190 axis. Example: Osmundacaulis skidegatensis.

2191 Dictyostelic: Having a dictyostele. 
2192 Dictyoxylic: Having a type of reticulate stele in which leaf gaps completely perforate the stelar

2193 metaxylem siphon such that in TS the siphon will appear like an interrupted ring of two or more

2194 separate stelar xylem segments.

2195 Dissected stele: Type of stele with external and internal endodermis layers that connect through

2196 (at least some) leaf gaps, thus completely enveloping stelar xylem segments (or groups thereof)

2197 in some TS of axis. Example: Guairea milleri.

2198 Heterogeneous sclerenchyma ring: A sclerenchyma ring in the stipe that, in its distal course

2199 away from the stem, develops distinct patches of particularly thick-walled fibres with

2200 characteristic arrangements beginning usually with an abaxial arch; proposed here as diagnostic

2201 of modern Osmundoideae.

2202 Immediate gap: Mode of formation of a complete leaf gap in which the gap breaks through to

2203 the pith immediately upon the departure of the trace from the stele; usually indicated already

2204 further below in the stele in the form of a notch or incision along the internal surface of the

2205 siphon.

2206 Incomplete gap: A leaf gap that does not perforate the stelar xylem siphon; formation of only

2207 incomplete gaps may be assumed in cases where the internal surface of the siphon is perfectly

2208 smooth and shows no notches, incisions, or embayments in a given TS.

2209 'Hewitson method': Method introduced by Hewitson (1962) for counting the number of stelar

2210 xylem segments in a given TS, in which only those xylem masses are recognized as individual

2211 segments that are completely separated from adjacent masses (i.e., not even connected by just a

2212 single tracheid); alternative approaches to determine the number of xylem segments might

2213 include, for instance, counting instead the number of protoxylem clusters in a given TS of the

2214 stelar xylem siphon. 
2215 Homogeneous sclerenchyma cylinder/ring: Stipe sclerenchyma cylinder that does not show a

2216 clear differentiation into regions composed of particularly thick-walled or completely occluded

2217 sclerenchyma cells (e.g., arches, masses, patches).

2218 Leaf trace: Within-stem portion of a vascular bundle supplying a leaf from the point where, in

2219 TS of axis, it appears completely separated from the stele up to the point where, in TS of axis, it

2220 departs from the stem to enter the stipe base and become the stipe vascular bundle.

2221 Leaf gap: Notch, incision, or perforation left in the external surface of the stelar xylem cylinder

2222 above a departed leaf trace; may be, for example, complete versus incomplete or immediate

2223 versus delayed.

2224 Mantle: Outer part of the axis enveloping the actual stem, composed usually of roots and

2225 persistent stipe bases; trunks of arborescent forms usually characterized by thick mantle with

2226 more or less vertical roots (i.e., roots mostly sectioned transversely in axis TS); rhizomes of non-

2227 arborescent Osmundales usually characterized by mantle with roots radiating out- and

2228 downwards in sinuous course (i.e., usually sectioned obliquely or longitudinally, but rarely

2229 transversely in axis TS), in some cases forming conspicuous mounds.

2230 Petiole: Stipe.

2231 Pith: Type of stem core consisting primarily of parenchyma, in some cases with varying

2232 amounts of sclerenchyma or interspersed tracheids.

2233 Plenasoid: Term initially introduced to illustrate one representative example for a mode of leaf-

2234 trace formation in which each trace is formed from two protoxylem poles originating from two

2235 adjacent stelar xylem segments; then adopted as one of a few 'types' of leaf-trace formation in

2236 Osmundales; here considered obsolete as a nominal category.

2237 Rhizome: The creeping to (semi-)erect axis characterizing a non-arborescent osmundalean plant. 
2238 Root trace: Within-stem portion of a vascular bundle supplying a root, from the point where, in

2239 TS of axis, it appears completely separated from the stele or leaf trace up to the point where, in

2240 TS of axis, it has departed from the stem and become the root vascular bundle.

2241 RS: Radial section.

2242 Sclerenchyma cylinder: a cylinder of sclerenchyma in the outer stipe cortex that derives from

2243 the outer stem cortex; may be homogeneous or heterogeneous; absent in Guaireaceae.

2244 Sclerenchyma ring: aspect of a sclerenchyma cylinder in a given TS.

2245 Semi-plenasoid: (here considered obsolete) A mode of leaf-trace formation in which each trace

2246 originates from a single protoxylem pole that begins to divide already in the stele, i.e., before the

2247 leaf-trace separates from the stele.

2248 Stele: Central part of the stem, excluding stem cortex; including all tissues contained inside the

2249 (external) stelar endodermis, such as stem core and stelar metaxylem siphon.

2250 Stem: Central part of the axis consisting of stele and cortex, excluding the mantle of roots and 2251 stipe bases.

2252 Stem core: The central part of the stele that is enveloped by the stelar metaxylem siphon; may

2253 consist primarily of tracheids or of a primarily parenchymatic pith with varying amounts of

2254 tracheids and/or sclerenchyma.

2255 Stem cortex: The outer part of the stem surrounding the stele, extending from external

2256 endodermis out to stem epidermis; traversed by root traces and leaf traces.

2257 Stipe (petiole): Leafless portion of a frond connecting the frond blade (lamina) to the stem; may

2258 bear stipular wings or spines.

2259 Trunk: The tall, upright form of axis characterizing an arborescent plant.

2260 TS: Transverse section. 
2261 Xylem segment, stelar x.s.: Anastomosing portion of the reticulate peripheral xylem siphon of a

2262 dictyoxylic stele that, in a given TS, appears as an isolated element separated from adjacent

2263 elements at each side by a complete ('Hewitson method') leaf gap.

2264 Xylem siphon, stelar x.s.: Distinct tube of xylem at the stele periphery; encloses the stem core;

2265 may show variable development of leaf gaps; shared by all Osmundales.

\section{Appendix C: Identification and classification key}

2267 A polytomous key for identification and classification of fossil osmundalean axes is provided in

2268 Figure 18. The concluding Figure 19 gives an overview of the taxic diversity and structural

2269 disparity of osmundalean axes grouped following the revised systematic treatment proposed in 2270 this paper. 
2271 Literature cited

2272 Andrews HN. 1950. A fossil osmundaceous tree-fern from Brazil. Bulletin of the Torrey

$2273 \quad$ Botanical Club 77:29-34.

2274 Archangelsky S, de la Sota E. 1962. Estudio anatómico de unestípite petrificado de

2275 "Osmundites", de edad Jurásica, procedente del Gran Bajo de San Julián, provincia de Santa Cruz. Ameghiniana 2:153-167.

2277 Archangelsky S, de la Sota E. 1963. Osmundites herbstii, nueva petrificación Triásica de El 2278 Tranquilo, provincia de Santa Cruz. Ameghiniana 3:135-140.

2279 Arnold CA. 1945. Silicified plant remains from the Mesozoic and Tertiary of western North 2280 America. I. Ferns. Papers of the Michigan Academy of Science, Arts, and Letters 30:3-34.

2281 Arnold CA. 1952. Fossil Osmundaceae from the Eocene of Oregon. Palaeontographica B 2282 92:63-78.

Arnold CA. 1964. Mesozoic and Tertiary fern evolution and distribution. Memoirs of the Torrey Botanical Club 21:58-66.

2285

2286

2287

Ash S. 1994. Donwelliacaulis chlouberii gen. et sp. nov. (Guaireaceae, Osmundales) one of the oldest Mesozoic plant megafossils in North America. Palaeontographica B 234:1-17.

Ashlock PD. 1971. Monophyly and associated terms. Systematic Zoology 20:63-69.

Auch AF, Henz SR, Holland BR, Göker M. 2006. Genome BLAST distance phylogenies inferred from whole plastid and whole mitochondrion genome sequences. $B M C$ Bioinformatics 7:350.

Bernhardi JJ. 1801. Schrader's Journal für die Botanik, II. Band. Göttingen: Heinrich Dieterich. 
2293 Blume CL. Enumeratio plantarum Javae et insularum adjacentium; minus cognitarum vel 2294 novarum ex herbariis Reinwardtii, Kuhlii, Hasseltii et Blumii, Fasciculus II. Leiden: JW 2295 van Leeuwen.

2296 Bomfleur B, Grimm GW, McLoughlin S. 2015. Osmunda pulchella sp. nov. from the Jurassic of Sweden — reconciling molecular and fossil evidence in the phylogeny of Osmundaceae. BMC Evolutionary Biology 15(126), 25pp.

Bomfleur B, McLoughlin S, Vajda V. 2014. Fossilized nuclei and chromosomes reveal 180 million years of genomic stasis in royal ferns. Science 343:1376-1377.

Bower FO. 1911. On medullation in the Pteridophyta. Annals of Botany 25:555-574.

2302 Bower FO. 1926. The ferns (Filicales) treated comparatively with a view to their natural classification. 2. The Eusporangiatae and other relatively primitive ferns. Cambridge: Cambridge University Press. Libraires-Éditeurs, quai Voltaire 13. New York, 375-391.

2314 Bryant D, Moulton V. 2004. Neighbor-Net: An agglomerative method for the construction of phylogenetic networks. Molecular Biology and Evolution 21:255-265. 
2316 Cantrill DJ. 1997. The pteridophyte Ashicaulis livingstonensis (Osmundaceae) from the Upper

2317 Cretaceous of Williams Point, Livingston Island, Antarctica. New Zealand Journal of

$2318 \quad$ Geology and Geophysics 40:315-323.

2319 Cantrill DJ, Webb JA. 1987. A reappraisal of Phyllopteroides Medwell (Osmundaceae) and its stratigraphic significance in the Lower Cretaceous of eastern Australia. Alcheringa 11:59_

Carruthers W. 1870. On the structure of a fern-stem from the Lower Eocene of Herne Bay, and on its allies, recent and fossil. Quarterly Journal of the Geological Society of London 26:349-354.

Chandler MEJ. 1965. The generic position of Osmundites dowkeri Carruthers. Bulletin of the British Museum of Natural History 10:139-162.

2327 Cheng Y-M. 2011. A new species of Ashicaulis (Osmundaceae) from the Mesozoic of China: a close relative of living Osmunda claytoniana. Review of Palaeobotany and Palynology 165:96-102.

Cheng Y-M, Li C-S. 2007. A new species of Millerocaulis (Osmundaceae, FIlicales) from the Middle Jurassic of China. Review of Palaeobotany and Palynology 144:249-259.

2332 Cheng Y-M, Wang Y-F, Li C-S. 2007. A new species of Millerocaulis (Osmundaceae) from the Middle Jurassic of China and its implication for evolution of Osmunda. International und wichtigeren Arten der Farnpflanzen mit besonderer Berücksichtigung der Exotischen. Jena: G Fischer. 
2338 Cobbett A, Wilkinson M, Wills MA. 2007. Fossils impact as hard as living taxa in parsimony 2339 analyses of morphology. Systematic Biology 56:753-766.

2340 Couper RA. 1953. Upper Mesozoic and Cainozoic spores and pollen grains from New Zealand. $2341 \quad$ New Zealand Geological Survey Palaeontological Bulletin 22:1-77.

2342 Couper RA. 1958. British Mesozoic microspores and pollen grains. A systematic and stratigraphic study. Palaeontographica B 103:75-179.

2344 Crepet WL, Stevenson DW. 2010. The Bennettitales (Cycadeoidales): a preliminary perspective on this arguably enigmatic group. In: Gee CT, ed. Plants in Mesozoic Time:

2346 Morphological Innovations, Phylogeny, Ecosystems. Bloomington: Indiana University Press, 215-244.

Darwin C. 1859. On the origin of species by means of natural selection, or the preservation of favoured races in the struggle for life. London: John Murray.

Daugherty LH. 1960. Itopsidema, a new genus of the Osmundaceae from the Triassic of Arizona. American Journal of Botany 47:771-777.

de Hoon MJL, Imoto S, Nolan J, Miyano S. 2004. Open source clustering software. Bioinformatics 20:1453-1454.

2354 Denk T, Grimm GW. 2009. Biogeographic history of beech trees. Review of Palaeobotany and Palynology 158:83-100.

Duby JE. 1828. Botanicon Gallicum, seu Synopsis Plantarum in Flora Gallica Descriptarum. Paris: Desray.

2358 Edwards WN. 1933. Osmundites from central Australia. Annals and Magazine of Natural 2359 History, Series 10, 11:661-663. 
2360 Eichwald E. 1842. Die Urwelt Russlands, durch Abbildungen erlaeutert. II. Heft. Sankt

2361 Petersburg: Kaiserliche Akademie der Wissenschaften.

2362 Eichwald E. 1860. Lethaea Rossica ou Paléontologie de la Russie. Stuttgart: E. Schweizerbart.

2363 Escapa IH, Cúneo NR. 2012. Fertile Osmundaceae from the Early Jurassic of Patagonia.

2364 International Journal of Plant Sciences 173:54-66.

2365 Farris JS. 1983. The logical basis of phylogenetic analysis. In: Platnick N, Funk V, eds.

2366 Advances in Cladistics. New York: Columbia University Press, 7-36.

2367 Faull JH. 1901. The anatomy of the Osmundaceae. Botanical Gazette 32:381-420.

2368 Faull JH. 1910. The stele of Osmunda cinnamomea. Transactions of the Royal Canadian

$2369 \quad$ Institute 8:515-534.

2370 Felsenstein J. 1985. Confidence limits on phylogenies: an approach using the bootstrap.

$2371 \quad$ Evolution 39:783-791.

2372 Felsenstein J. 2001. The troubled growth of statistical phylogenetics. Systematic Biology

$2373 \quad 50: 465-467$.

2374 Felsenstein J. 2004. Inferring phylogenies. Sunderland, MA, U.S.A.: Sinauer Associates.

2375 Friis EM, Crane PR, Pedersen KR, Bengtson S, Donoghue PCJ, Grimm, GW, Stampanoni

2376 M. 2007. Phase-contrast X-ray microtomography links Cretaceous seeds with the Gnetales 2377 and Bennettitales. Nature 450:549-552.

2378 Galtier J, Wang S-J, Li C-S, Hilton J. 2001. A new genus of filicalean fern from the Lower 2379 Permian of China. Botanical Journal of the Linnean Society 137:429-442.

2380 Gascuel O. 1997. BIONJ: An improved version of the NJ algorithm based on a simple model of 2381 sequence data. Molecular Biology and Evolution 14:685-695. 
2382 Gorskii II. 1944. Geology of the USSR XII. Leningrad-Moscow: State Geological Publishing. 2383 [in Russian]

2384 Gould RE. 1970. Palaeosmunda, a new genus of siphonostelic osmundaceous trunks from the $2385 \quad$ Upper Permian of Queensland. Palaeontology 13:10-28.

2386 Gould RE. 1973. A new species of Osmundacaulis from the Jurassic of Queensland.

2387 Proceedings of the Linnean Society of New South Wales 98:86-94.

2388 Grimm GW, Kapli P, Bomfleur B, McLoughlin S, Renner SS. 2015. Using more than the 2389 oldest fossils: Dating Osmundaceae by three Bayesian clock approaches. Systematic 2390 Biology 46:396-405.

2391 Gupta KM. 1970. Investigations on the Jurassic flora of the Rajmahal Hills, India. 8. On a new species of Osmundites rajmahalense sp. nov. from the Rajmahal Hills, Bihar (India). Palaeontographica B 130:173-180.

2394 Gwynne-Vaughan DT. 1911. Some remarks on the anatomy of the Osmundaceae. Annals of 2395 Botany 25:525-536.

2396 Gwynne-Vaughan DT. 1914. On a 'mixed pith' in an anomalous stem of Osmunda regalis. $2397 \quad$ Annals of Botany 28:351-354.

2398 Haeckel E. 1866. Allgemeine Anatomie der Organismen-Kritische Grundzüge der mechanischen Wissenschaft von den entwickelten Formen der Organismen, begründet durch die Descendenz-Theorie. Berlin: Georg Reimer. type. Arkiv Botanik 10(15):1-10.

2403 Harris TM. 1931. The fossil flora of Scoresby Sound, East Greenland. Part 1: Cryptogams 2404 (exclusive of Lycopodiales). Meddelelser om Grönland 85(5):1-133. 
2405 Hendricks JR, Saupe EE, Myers CE, Hermsen EJ, Allmon WD. 2014. The generification of 2406 the fossil record. Paleobiology 40:511-528.

2407 Hennig W. 1950. Grundzüge einer Theorie der phylogenetischen Systematik. Berlin: Dt.

$2408 \quad$ Zentralverlag.

2409 Hennipman E. 1968. A new Todea from New Guinea with remarks on the generic delimitation 2410 in recent Osmundaceae (Filices). Blumea 16:105-108.

2411 Herbst R. 1977. Dos nuevas especies de Osmundacaulis (Osmundaceae, Filices) y otros restos 2412 de Osmundales de Argentina. Facena 1:19-40.

2413 Herbst R. 1981. Guairea milleri nov. gen. et sp. y Guaireaceae, nueva familia de las $2414 \quad$ Osmundales (sensu lato) del Pérmico Superior de Paraguay. Ameghiniana 18:35-50.

2415 Herbst R. 1994. A new genus of thamnopteridoid ferns (Osmundaceae, Filicales) from the 2416 Upper Triassic Carrizal Formation of Marayes, Province San Juan, Argentina. Acta $2417 \quad$ Geologica Leopoldensia 17:93-107.

2418 Herbst R. 1995. Millerocaulis stipabonettii nov. sp. (Osmundaceae, Filices) from the Late 2419 Triassic La Cepeda Formation of San Juan Province, Argentina. Mededelingen Rijks $2420 \quad$ Geologische Dienst 53:13-19.

2421 Herbst R. 2001. A revision of the anatomy of Millerocaulis patagonica (Archangelsky and de la Sota) Tidwell (Filices, Osmundaceae), from the Middle Jurassic of Santa Cruz Province, Argentina. Eleventh Simposio Argentino de Paleobotánica y Palinología. Asociación Paleontológica Argentina, Publicación Especial 8:39-48.

Herbst R. 2003. Osmundacaulis tehuelchense nov.sp. (Osmundaceae, Filices) from the Middle Jurassic of Santa Cruz Province (Patagonia, Argentina). Courier Forschungsinstitut Senckenberg 241:85-95. 
2428 Herbst R. 2006. Millerocaulis (Erasmus) ex Tidwell (Osmundales, Filices) de la Formación

2429 Carrizal (Triásico Superior) de Marayes, provincia de San Juan, Argentina. Revista del

$2430 \quad$ Museo Argentino de Ciencias Naturales, Nueva Série 8:185-193.

2431 Herbst R. 2008. La filotaxis en Osmundales (Filices) fósiles. Revista del Museo Argentino de

2432 Ciencias Naturales, Nueva Série 10:263-271.

2433 Herbst R. 2015. The Osmundaceae (Filices) from the Cretaceous of South Africa: new species $2434 \quad$ and revision. Palaeontologia Africana 49:25-41.

2435 Herbst R, Barboni R, Dutra TL. 2012. El género Guairea Herbst (Guaireaceae, Osmundales) en el Triásico, Rio Grande do Sul, Brasil. XV Simposio Argentino de Paleobotánica y Palinología, Corrientes [conference abstract]. Botanical Garden 49:57-93.

Hill RS, Forsyth SM, Green F. 1989. A new genus of osmundaceous stem from the Upper Triassic of Tasmania. Palaeontology 32:287-296.

2442 Hillis DM, Wiens JJ. 2000. Molecules versus morphology in systematics: conflicts, artefacts, and misconceptions. In: Wiens JJ, ed. Phylogenetic Analysis of Morphological Data. Washington, DC: Smithsonian Institution Press, 1-19. of the Torrey Botanical Society 133:119-168.

2447 Hooker WJ. 1837. Icones Plantarum, or Figures, with Brief Descriptive Characters and 2448 Remarks, of New or Rare Plants, Selected from the Author's Herbarium. London:

2449 Longman, Rees, Orme, Brown, Green \& Longman. 
2450 Hörandl E. 2006. Paraphyletic versus monophyletic taxa - evolutionary versus cladistic $2451 \quad$ classifications. Taxon 55:564-570.

2452 Hörandl E. 2007. Neglecting evolution is bad taxonomy. Taxon 56:1-5.

2453 Huson DH, Bryant D. 2006. Application of phylogenetic networks in evolutionary studies.

$2454 \quad$ Molecular Biology and Evolution 23:254-267.

2455 Jud NA, Rothwell GW, Stockey RA. 2008. Todea from the Lower Cretaceous of western North 2456 America: implications for the phylogeny, systematics, and evolution of modern 2457 Osmundaceae. American Journal of Botany 95:330-339.

2458 Kidston R, Gwynne-Vaughan DT. 1907. On the fossil Osmundaceae. Part I. Transactions of 2459 the Royal Society of Edinburgh 45:759-780.

2460 Kidston R, Gwynne-Vaughan DT. 1908. On the fossil Osmundaceae. Part II. Transactions of 2461 the Royal Society of Edinburgh 46:213-232.

2462 Kidston R, Gwynne-Vaughan DT. 1909. On the fossil Osmundaceae. Part III. Transactions of 2463 the Royal Society of Edinburgh 46:651-667.

2464 Kidston R, Gwynne-Vaughan DT. 1910. On the fossil Osmundaceae. Part IV. Transactions of 2465 the Royal Society of Edinburgh 47:455-477.

2466 Kidston R, Gwynne-Vaughan DT. 1914. On the fossil Osmundaceae. Part V. Transactions of 2467 the Royal Society of Edinburgh 50:469-480.

2468 Kuhn M. 1869. Filices. Annales Musei Botanici Lugduno-Batavi 4:276-300.

2469 Lewis PO. 2001. A likelihood approach to estimating phylogeny from discrete morphological $2470 \quad$ character data. Systematic Biology 50:913-925.

2471 Li C, Cui J. 1995. Atlas of Fossil Plant Anatomy in China. CRC Beijing: Science Press. 
2472 Li Z-M. 1983. Palaeosmunda emended and two new species. Acta Phytotaxonomica Sinica

$2473 \quad 21: 153-160$. (in Chinese with English abstract)

2474 Li Z-M. 1993. The genus Shuichengella gen. nov. and systematic classification of the order 2475 Osmundales. Review of Palaeobotany and Palynology 77:51-63.

2476 Linnaeus C. 1753. Species plantarum, exhibentes plantas rite cognitas, ad genera relatas, cum 2477 differentiis specificis, nominibus trivialibus, synonymis selectis, locis natalibus, secundum systema sexuale digestas. Stockholm: L Salvius.

2479 Link HF. 1833. Hortus Regius Botanicus Berolinensis, Tomus II. Berlin: G Reimer.

2480 Maithy PK. 1974. Dichotomopteris, a new type of fern frond from the Lower Gondwana of $2481 \quad$ India. Palaeobotanist 21:365-367.

2482 Marshall P. 1926. A new species of Osmundites from Kawhia, New Zealand. Transactions of 2483 the New Zealand Institute 56:210-213.

2484 Martynov II. 1820. Tekhno-Botanicheskii Slovar. St Petersburg: Proceedings of the Imperial $2485 \quad$ Russian Academy.

2486 Matsumoto M, Nishida H. 2003. Osmunda shimokawaensis sp. nov. and Osmunda cinnamomea 2487 L. based on permineralized rhizomes from the Middle Miocene of Shimokawa, Hokkaido, $2488 \quad$ Japan. Paleontological Research 7:153-165.

2489 Matsumoto M, Seiki K, Zhang W, Zheng S, Wang Y. 2006. A new species of osmundaceous 2490 fern rhizome, Ashicaulis macromedullosus sp. nov., from the Middle Jurassic, northern 2491 China. Paleontological Research 10:195-205.

2492 Mayr E, Bock WJ. 2002. Classifications and other ordering systems. Journal of Zoological $2493 \quad$ Systematics and Evolutionary Research 40:169-194. 
2494 McLoughlin S. 1992. Late Permian plant megafossils from the Bowen Basin, Queensland, 2495 Australia: Part 1. Palaeontographica B 228:105-149.

2496 Metzgar JS, Skog JE, Zimmer EA, Pryer KM. 2008. The paraphyly of Osmunda is confirmed 2497 by phylogenetic analyses of seven plastid loci. Systematic Botany 33:31-36.

2498 Miller CN. 1967. Evolution of the fern genus Osmunda. Contribution from the Museum of $2499 \quad$ Paleontology 21:139-203.

2500 Miller CN. 1971. Evolution of the fern family Osmundaceae based on anatomical studies. 2501 Contribution from the Museum of Paleontology 23:105-169.

2502 Miller CN. 1982. Osmunda wehrii, a new species based on petrified rhizomes from the Miocene 2503 of Washington. American Journal of Botany 69:116-121.

Moore T. 1857. Index Filicum: a Synopsis, with Characters, of the Genera, and an Enumeration 2505 of the Species of Ferns, with Synonymes, References, etc. etc. London: W Pamplin. Bayesian approaches in the investigation of a basal fossil clade. Systematic Biology 55:503-511.

Müller J, Reisz RR. 2006. The phylogeny of early Eureptiles: Comparing parsimony and

Pant D, Khare P. 1974. Damudopteris gen. nov. a new genus of ferns from the Lower Gondwanas of the Raniganj coalfield, India. Proceedings of the Royal Society of London B 186:121-135.

Penhallow DP. 1902a. Osmundites skidegatensis n. sp. Transactions of the Royal Society of Canada, $2^{\text {nd }}$ series 8:3-29. Royal Society of Canada, $2^{\text {nd }}$ series 8:31-91. 
2516 Phipps CJ, Taylor TN, Taylor EL, Cúneo R, Boucher, LD, Yao X. 1998. Osmunda

2517 (Osmundaceae) from the Triassic of Antarctica: an example of evolutionary stasis.

2518 American Journal of Botany 85:888-895.

2519 PPG I. 2016. A community-derived classification for extant lycophytes and ferns. Journal of $2520 \quad$ Systematics and Evolution 54:563-603.

2521 Presl CB. 1836. Tentamen Pteridographiae, seu Genera Filicacearum Praesertim Juxta 2522 Venarum Decursum et Distributionem Exposita. Praha: T Haase.

2523 Presl CB. 1845. Supplementum Tentaminis Pteridographiae, continens Genera et Species

2524 Ordinum Dictorum Marattiaceae, Ophioglossaceae, Osmundaceae, Schizaeaceae et 2525 Lygodiaceae. Abhandlungen der Mathematisch-Naturwissenschaftlichen Classe der 2526 Königlichen Böhmischen Gesellschaft der Wissenschaften 4:261-380.

2527 Presl KB. 1848. Die Gefäßbündel im Stipes der Farrn. Abhandlungen der Mathematisch2528 Naturwissenschaftlichen Classe der Königlichen Böhmischen Gesellschaft der Wissenschaften 5:307-356.

2530

2531

2532
Prynada VD. 1974. O nakhodke roda Osmundites v verkhnetriasovykh otlozhenijakh vostochnogo sklona Urala. Trudy Vsesoyuznogo Nauchno-Issledovatel'skogo Geologicheskogo Instituta 182:252-263.

Rößler R, Galtier J. 2002. First Grammatopteris tree ferns from the Southern Hemispherenew insights in the evolution of the Osmundaceae from the Permian of Brazil. Review of Palaeobotany and Palynology 121:205-230.

Rothwell GW, Crepet WL, Stockey RA. 2009. Is the anthophyte hypothesis alive and well? New evidence from the reproductive structures of Bennettitales. American Journal of Botany 96:296-322. 
2539 Rothwell GW, Stockey RA. 2008. Phylogeny and evolution of ferns: a paleontological

2540

2541

2542

2543

2544

2545

2546

2547

2548

2549

2550

2551

2552

2553

2554

2555

2556

2557

2558

2559

2560

2561

perspective. In: Ranker TA, Haufler CH, eds. Biology and Evolution of Ferns and Lycophytes. Cambridge: Cambridge University Press.

Rothwell GW, Taylor EL, Taylor TN. 2002. Ashicaulis woolfei n. sp.: Additional evidence for the antiquity of osmundaceous ferns from the Triassic of Antarctica. American Journal of Botany 89:352-361.

Sagasti AJ, García Massini J, Escapa IH, Guido DM, Channing A. 2016. Millerocaulis zamunerae sp. nov. (Osmundaceae) from Jurassic, geothermally influenced, wetland environments of Patagonia, Argentina. Alcheringa 40:456-474.

Sahni B. 1932. On a Paleozoic tree-fern, Grammatopteris baldaufi (Beck) Hirmer, a link between the Zygopterideae and Osmundaceae. Annals of Botany 46:863-877.

Saitou N, Nei M. 1987. The neighbor-joining method: A new method for reconstructing phylogenetic trees. Molecular Biology and Evolution 4:406-425.

Schelpe EACLC. 1955. Osmundites natalensis-A new fossil fern from the Cretaceous of Zululand. Annals and Magazine of Natural History, Series 12 8:652-656.

Schelpe EACLC. 1956. Osmundites atherstonei-a new Cretaceous fern from Cape Province, South Africa. Annals and Magazine of Natural History, Series 12 9:330-332.

Schliep K, Potts AJ, Morrison DA, Grimm GW. 2017. Intertwining phylogenetic trees and networks. Methods in Ecology and Evolution DOI: 10.1111/2041-210X.12760.

Schmid R. 1982. The terminology and classification of steles: Historical perspective and the outlines of a system. Botanical Review 48:817-931.

Schopf JM. 1978. An unusual osmundaceous specimen from Antarctica. Canadian Journal of Botany 56:3083-3095. 
2562 Schuettpelz E, Pryer KM. 2007. Fern phylogeny inferred from 400 leptosporangiate species

$2563 \quad$ and three plastid genes. Taxon 56:1037-1050.

2564 Schuster J. 1911. Osmundites von Sierra Villa Rica in Paraguay. Berichte der Deutschen

2565 Botanischen Gesellschaft 39:534-539.

2566 Scotland RW, Olmstead RG, Bennett JR. 2003. Phylogeny reconstruction: The role of

2567 morphology. Systematic Biology 52:539-548.

2568 Scotland RW, Steel M. 2015. Circumstances in which parsimony but not compatibility will be 2569 provably misleading. Systematic Biology 64:492-504.

2570 Serbet R, Rothwell GW. 1999. Osmunda cinnamomea (Osmundaceae) in the Upper Cretaceous 2571 of Western North America: Additional evidence for exceptional species longevity among 2572 filicalean ferns. International Journal of Plant Sciences 160:425-433.

2573 Seward AC. 1900. The Jurassic flora, I. The Yorkshire Coast. Catalogue of the Mesozoic plants 2574 in the Department of Geology. British Museum (Natural History) 3:1-341.

2575 Seward AC. 1907. Notes on fossil plants from South Africa. Geological Magazine, New Series $2576 \quad$ (Decade 5) 4:481-487.

2577 Seward AC, Ford SO. 1903. The anatomy of Todea, with notes on the geological history and 2578 affinities of the Osmundaceæ. Transactions of the Linnean Society of London, 2nd Series, $2579 \quad$ Botany 6:237-260.

2580 Sharma BD. 1973. Anatomy of osmundaceous rhizomes collected from the Middle Jurassic of 2581 Amarjola in the Rajmahal Hills, India. Palaeontographica B 140:151-160.

2582 Sharma BD, Bohra DR, Singh R. 1979. Osmundacaulis estipulare sp. nov.- - a petrified 2583 rhizome from Jurassic of Rajmahal Hills, India. Phytomorphology 29:46-52. 
2584 Simpson GG. 1945. The principles of classification and a classification of mammals. Bulletin of 2585 the American Museum of Natural History 85:1-350.

2586 Sinnott EW. 1914. Some Jurassic Osmundaceae from New Zealand. Annals of Botany 28: 471$2587 \quad 479$.

2588 Smith AR, Pryer KM, Schuettpelz E, Korall P, Schneider H, Wolf PG. 2006. A classification 2589 for extant ferns. Taxon 55:705-731.

2590 Smith MA, Rothwell GW, Stockey RA. 2015. Mesozoic diversity of Osmundaceae:

2591 Osmundacaulis whittlesii sp. nov. in the Early Cretaceous of western Canada. International 2592 Journal of Plant Sciences 176:245-258.

2593 Spencer M, Davidson EA, Barbrook AC, Howe CJ. 2004. Phylogenetics of artificial 2594 manuscripts. Journal of Theoretical Biology 227:503-511.

2595 Stamatakis A, Hoover P, Rougemont J. 2008. A rapid bootstrap algorithm for the RAxML 2596 web servers. Systematic Biology 57:758-771.

2597 Stamatakis A. 2014. RAxML version 8: a tool for phylogenetic analysis and post-analysis of 2598 large phylogenies. Bioinformatics 30:1312-1313.

2599 Stockey RA, Smith SY. 2000. A new species of Millerocaulis (Osmundaceae) from the Lower 2600 Cretaceous of California. International Journal of Plant Sciences 161:159-166.

2601 Stopes MC. 1921. The missing link in Osmundites. Annals of Botany 35:55-61.

2602 Sweet R. 1826. Sweet's Hortus Britannicus: or a catalogue of plants cultivated in the gardens of 2603 Great Britain, arranged in natural orders, Pt I. London: J Ridgway.

2604 Swofford DL. 2002. PAUP*: Phylogenetic analysis using parsimony (and other methods). 4.0 2605 beta 10 ed. Sunderland, MA: Sinauer Associates. 
2606 Taylor TN, Taylor EL, Meyer-Berthaud B, Isbell JL Cúneo NR. 1990. Triassic

2607

2608

2609

2610

2611

2612

2613

2614

2615

2616

2617

2618

2619

2620

2621

2622

2623

2624

2625

2626 osmundaceous ferns from the Allan Hills, southern Victoria Land. Antarctic Journal of the United States 25(5):18-20.

Testo W, Sundue M. 2016. A 4000-species dataset provides new insight into the evolution of ferns. Moleculiar Phylogenetics and Evolution 105:200-211.

Thunberg CP. 1780. Kaempferus illustratus: Explicatio illarum plantarum quas Kaempferus in Iaponia collegit et in fasciculo Quinto Amoenitatum exoticarum adnotavit [...] Nova Acta Regiae Societatis Scientiarum Upsaliensis 3:196-209.

Thunberg CP. 1784. Flora Japonica. Lipsia: IG Mueller.

Tian N, Wang Y-D, Dong M, Li L-Q, Jiang Z-K. 2016. A systematic overview of fossil osmundalean ferns in China: Diversity variation, distribution pattern, and evolutionary implications. Palaeoworld 25:149-169.

Tian N, Wang Y-D, Jiang Z-K. 2008. Permineralized rhizomes of the Osmundaceae (Filicales): Diversity and tempo-spatial distribution pattern. Palaeoworld 17:183-200.

Tian N, Wang Y-D, Philippe M, Zhang W, Jiang Z-K, Li L-Q. 2014a. A specialized new species of Ashicaulis (Osmundaceae, Filicales) from the Jurassic of Liaoning, NE China. Journal of Plant Research 127:209-219.

Tian N, Wang Y-D, Zhang W, Jiang Z-K. 2014b. A new structurally preserved fern rhizome of Osmundaceae (Filicales) Ashicaulis wangii sp. nov. from the Jurassic of western Liaoning and its significances for palaeobiogeography and evolution. Science China: Earth Sciences 57:671-681. 
2627 Tian N, Wang Y, Zhang W, Jiang Z, Dilcher DL. 2013. Ashicaulis beipiaoensis sp. nov., a

2628

2629

2630

2631

2632

2633

2634

2635

2636

2637

2638

2639

2640

2641

2642

2643

2644

2645

2646

2647

2648

new osmundaceous fern species from the Middle Jurassic of Liaoning Province, northeastern China. International Journal of Plant Sciences 174:328-339.

Tidwell WD. 1986. Millerocaulis, a new genus with species formerly in Osmundacaulis Miller (fossils: Osmundaceae). SIDA 11:401-405.

Tidwell WD. 1987. A new species of Osmundacaulis (O. jonesii sp. nov.) from Tasmania, Australia. Review of Palaeobotany and Palynology 52:205-216.

Tidwell WD. 1990. A new osmundaceous species (Osmundacaulis lemonii n.sp.) from the Upper Jurassic Morrison Formation, Utah. Hunteria 2:1-6.

Tidwell WD. 1991. Lunea jonesii gen. et sp. nov., a new member of Guaireaceae from the midMesozoic of Tasmania, Australia. Palaeontographica B 223:81-90.

Tidwell WD. 1992. Millerocaulis richmondii sp. nov., an osmundaceous fern from Mesozoic strata near Little Swanport, Tasmania, Australia. Papers and Proceedings of the Royal Society of Tasmania 126:1-7.

Tidwell WD. 1994. Ashicaulis, a new genus for some species of Millerocaulis (Osmundaceae). SIDA 16:253-261.

Tidwell WD. 2002. The Osmundaceae - a very ancient group of ferns. In: Dernbach U, Tidwell WD, eds. Secrets of Petrified Plants. Heppenheim: D’Oro Publishers.

Tidwell WD, Ash SR. 1994. A review of selected Triassic to Early Cretaceous ferns. Journal of Plant Research 107:417-442.

Tidwell WD, Clifford HT. 1995. Three new species of Millerocaulis (Osmundaceae) from Queensland, Australia. Australian Systematic Botany 8:667-685. 
2649 Tidwell WD, Jones R. 1987. Osmundacaulis nerii, a new osmundaceous species from

2650

2651

2652

2653

2654

2655

2656

2657

2658

2659

2660

2661

2662

2663

2664

2665

2666

2667

2668

2669

2670

2671

Tasmania, Australia. Palaeontographica B 204:181-191.

Tidwell WD, Medlyn DA. 1991. Two new species of Aurealcaulis (Osmundaceae) from northwestern New Mexico. Great Basin Naturalist 51:325-335.

Tidwell WD, Munzing GE, Banks MR. 1991. Millerocaulis species (Osmundaceae) from Tasmania, Australia. Palaeontographica B 223:91-105.

Tidwell WD, Parker LR. 1987. Aurealcaulis crossii gen. et sp. nov., an arborescent, osmundaceous trunk from the Fort Union Formation (Paleocene), Wyoming. American Journal of Botany 74:803-812.

Tidwell WD, Pigg KB. 1993. New species of Osmundacaulis emend. from Tasmania, Australia. Palaeontographica B 230:141-158.

Tidwell WD, Rozefelds AC. 1990. Grammatocaulis donponii gen. et sp. nov., a permineralized fern from the Jurassic of Queensland, Australia. Review of Palaeobotany and Palynology 66:147-158.

Tidwell WD, Rushforth SR. 1970. Osmundacaulis wadei, a new osmundaceous species from the Morrison Formation (Jurassic) of Utah. Bulletin of the Torrey Botanical Club 97:137144.

Tidwell WD, Skog JE. 2002. Three new species of Aurealcaulis (A. burgii sp. nov., A. dakotensis sp. nov., and A. nebraskensis sp. nov.) from South Dakota and Nebraska, USA. Palaeontographica B 262:25-37.

Tschopp E, Mateus O, Benson RBJ. 2015. A specimen-level phylogenetic analysis and taxonomic revision of Diplodocidae (Dinosauria, Sauropoda). PeerJ 3:e857; DOI 10.7717 peerj. 857 
2672 Unger F. 1854. Ein fossiles Farnkraut aus der Ordnung der Osmundaceen nebst vergleichenden

2673 Skizzen über den Bau des Farnstammes. Denkschriften der Kaiserlichen Akademie der

2674 Wissenschaften, Mathematisch-naturwissenschaftliche Klasse 10:137-151.

2675 Upchurch P, Tomida Y, Barrett PM. 2004. A new specimen of Apatosaurus ajax (Sauropoda:

2676 Diplodocidae) from the Morrison Formation (Upper Jurassic) of Wyoming, USA. National

2677 Science Museum Monographs 26:1-108.

2678 Van Wyk AE. 2007. The end justifies the means. Taxon 56:645-648.

2679 Vera EI. 2007. A new species of Ashicaulis Tidwell (Osmundaceae) from Aptian strata of 2680 Livingston Island, Antarctica. Cretaceous Research 28:500-508.

2681 Vera EI. 2008. Proposal to emend the genus Millerocaulis Erasmus ex Tidwell 1986 to

2682 recombine the genera Ashicaulis Tidwell 1994 and Millerocaulis Tidwell emend. Tidwell

2683 1994. Ameghiniana 45:693-698.

Vera EI. 2010. A new specimen of Millerocaulis (Osmundales: Osmundaceae) from the Cerro Negro Formation (Lower Cretaceous), Antarctica. Revista del Museo Argentino de Ciencias Naturales, Nueva Série 12:41-46.

Vera EI. 2012. Millerocaulis tekelili sp. nov., a new species of osmundalean fern from the Aptian Cerro Negro Formation (Antarctica). Alcheringa 36:35-45.

2689 Vishnu-Mittre 1955. Osmundites sahnii sp. nov., a new species of petrified osmundaceous rhizomes from India. The Palaeobotanist 4:113-118.

Wang S-J, Hilton J, Galtier J, He X-Y, Shao L-Y. 2014a. Tiania yunnanense gen. et sp. nov., an osmundalean stem from the Upper Permian of southwestern China previously placed within Palaeosmunda. Review of Palaeobotany and Palynology 210:37-49. 
2694 Wang S-J, Hilton J, He X-Y, Seyfullah LJ, Shao L. 2014b. The anatomically preserved 2695 Zhongmingella gen. nov. from the Upper Permian of China: evaluating the early evolution 2696 and phylogeny of the Osmundales. Journal of Systematic Palaeontology 1:1-22.

2697 Wang Z. 1983. Osmundacaulis hebeiensis, a new species of fossil rhizomes from the Middle 2698 Jurassic of China. Review of Palaeobotany and Palynology 39:87-107.

2699 Wardlaw CW. 1946. Experimental and analytical studies of pteridophytes. VII. Stelar 2700 morphology: The effect of defoliation on the stele of Osmunda and Todea. Annals of

2701

2702

Wardlaw CW. 1947. Experimental and analytical studies of pteridophytes. X. The size-structure correlation in the filicinean vascular system. Annals of Botany 11:203-217.

Wiens JJ. 2004. The role of morphological data in phylogeny reconstruction. Systematic Biology 2705 53:653-661.

Yatabe Y, Murakami N, Iwatsuki K. 2005. Claytosmunda; a new subgenus of Osmunda (Osmundaceae). Acta Phytotaxonomica et Geobotanica 56:127-128.

Yatabe Y, Nishida H, Murakami N. 1999. Phylogeny of Osmundaceae inferred from rbcL nucleotide sequences and comparison to the fossil evidences. Journal of Plant Research Botany 46:347-358.

Zalessky MD. 1927. Flore permienne de limites ouraliennes de l'Angaride. Memoires du Comité 2714 Géologique 174:1-76. 
2715 Zalessky M. 1931a. Structure anatomique du stipe du Chasmatopteris principalis n. gen. et sp., 2716 un nouveau représentant des Osmundacées permiennes. Bulletin de l'Académie des 2717 Sciences de l'URSS, Classe des Sciences Mathématiques et Naturelles 1931:715-720.

2718 Zalessky M. 1931b. Structure anatomique du stipe du Petcheropteris splendida n. g. et sp., un nouveau représentant des Osmundacées permiennes. Bulletin de l'Académie des Sciences de l'URSS, Classe des Sciences Mathématiques et Naturelles 1931:705-710.

2721 Zalessky MD. 1935. Structure anatomique du stipe d'une nouvelle Osmondée de terrain Permien 2722 du Bassin de Kousnetzk. Bulletin de l'Académie des Sciences de l'URSS, Classe des $2723 \quad$ Sciences Mathématiques et Naturelles 1935:747-752.

2724 Zhang W, Zheng S-L. 1991. A new species of osmundaceous rhizome from Middle Jurassic of 2725 Liaoning, China. Acta Palaeontologica Sinica 30:714-727. 
2726 Figures and figure captions

\section{Figure 1}

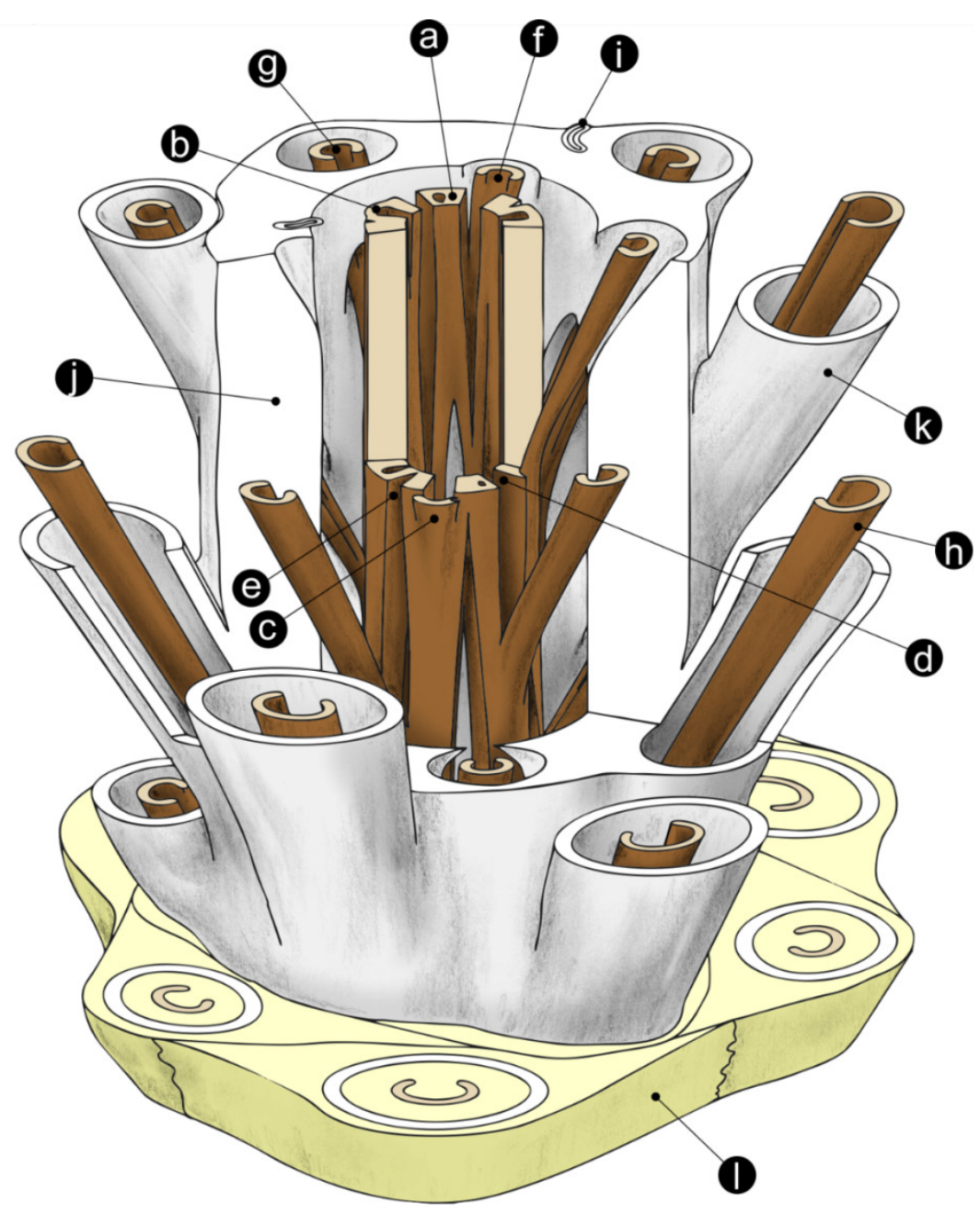

2728

2729 Figure 1. Diagrammatic representation of a cutout stem portion of a Millerocaulis-type

2730 osmundoidalean rhizome (Osmundoideae, Osmundaceae) showing a selection of general

2731 anatomical features. Petiolar parenchyma in yellow-green; outer and inner surface of

2732 sclerenchymatic outer cortex in light grey; xylem in brown; parenchyma of pith and inner

2733 cortices left transparent and most roots omitted for clarity reasons.

2734 Labelled features are as follows: $\mathbf{a}=$ stelar xylem segment; $\mathbf{b}=$ internal embayment in

2735 metaxylem siphon indicative of an incipient leaf-gap formation; $\mathbf{c}=$ departing leaf trace; $\mathbf{d}=$ leaf 
2736 gap forming complete perforation of the xylem cylinder immediately upon departure of leaf

2737 trace; $\mathbf{e}=$ peripheral incision into stelar xylem cylinder above departed leaf trace; $\mathbf{f}=$ leaf trace in

2738 inner stem cortex; $\mathbf{g}=$ leaf trace in outer stem cortex; $\mathbf{h}=$ stipe vascular bundle; $\mathbf{i}=$ root trace

2739 upon departure from stem. Anatomical features of cortex and mantle: $\mathbf{j}=$ outer sclerenchymatic

2740 stem cortex; $\mathbf{k}$ = stipe sclerenchyma cylinder ('sclerenchyma ring' in TS); $\mathbf{I}=$ stipular wings

2741 forming part of the mantle. A pdf version of this image without labels is provided in the

2742 Supplemental Materials.

2743 


\section{Figure 2}

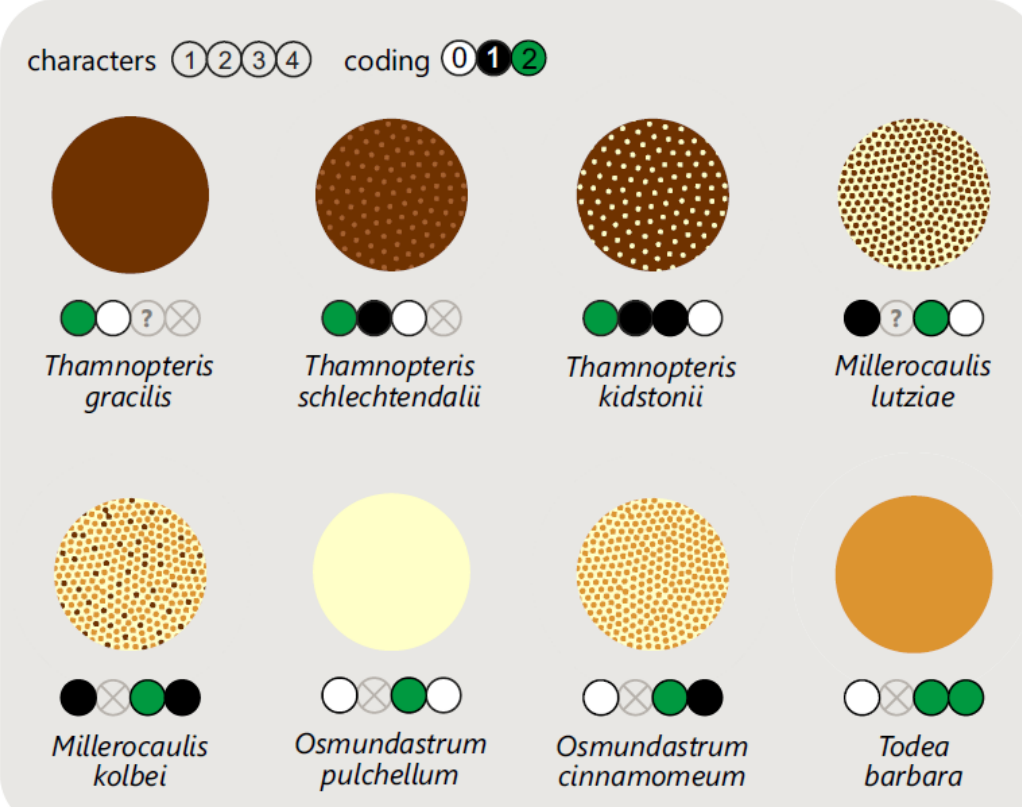

Figure 2. Diagram showing different tissue compositions of selected types of osmundalean stem

2747 cores as seen in cross-section through the stem core, together with the respective character

2748 scoring used in the matrix (for definition of characters and of character states see text). A gradual

2749 transition can be drawn from only tracheids (Thamnopteris gracilis) to parenchyma to fully

2750 sclerified stem cores (extant Todea barbara). Parenchyma in pale yellow; sclerenchyma in light

2751 brown; tracheids/xylem in dark brown.

2752 


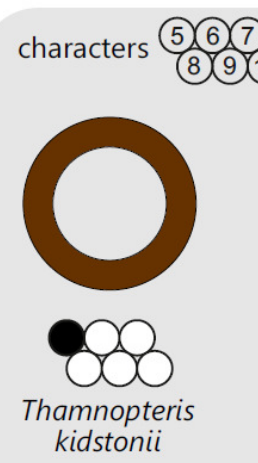

coding (0) 12
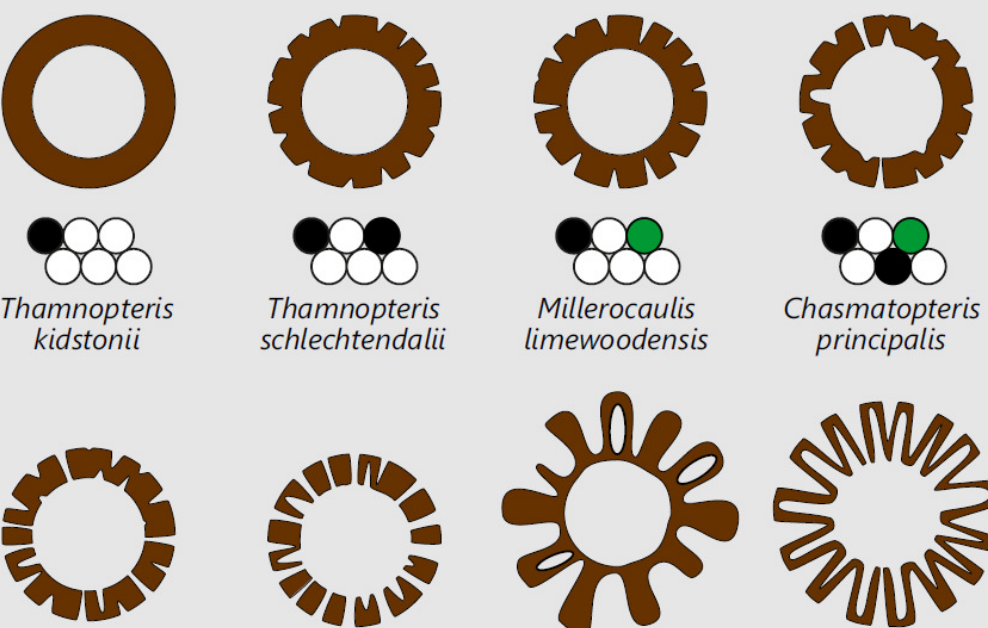

Thamnopteris

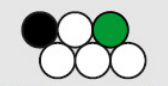

schlechtendalii

Millerocaulis limewoodensis
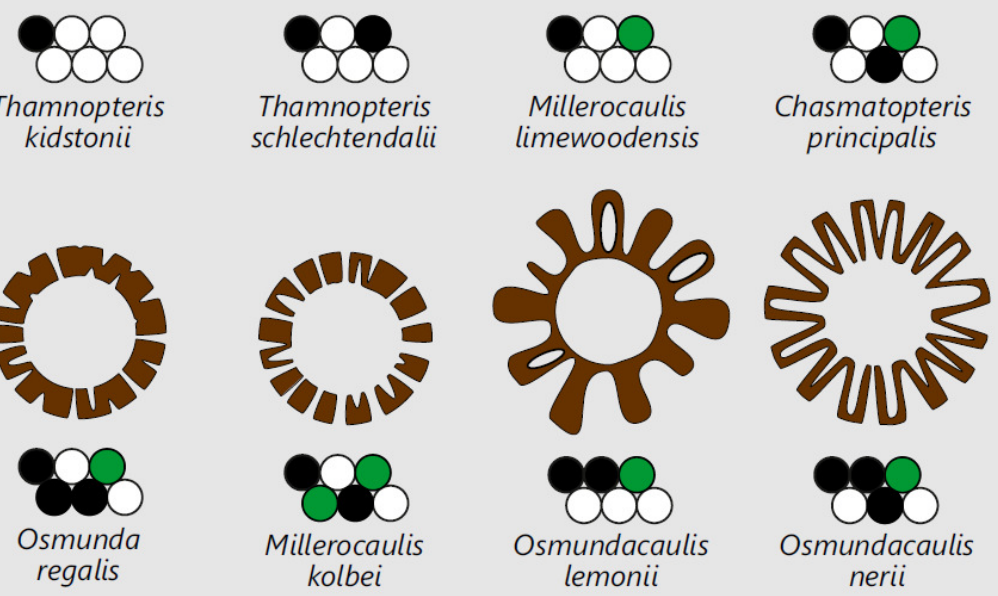
regalis

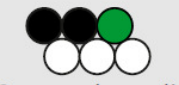

Osmundacaulis lemonii
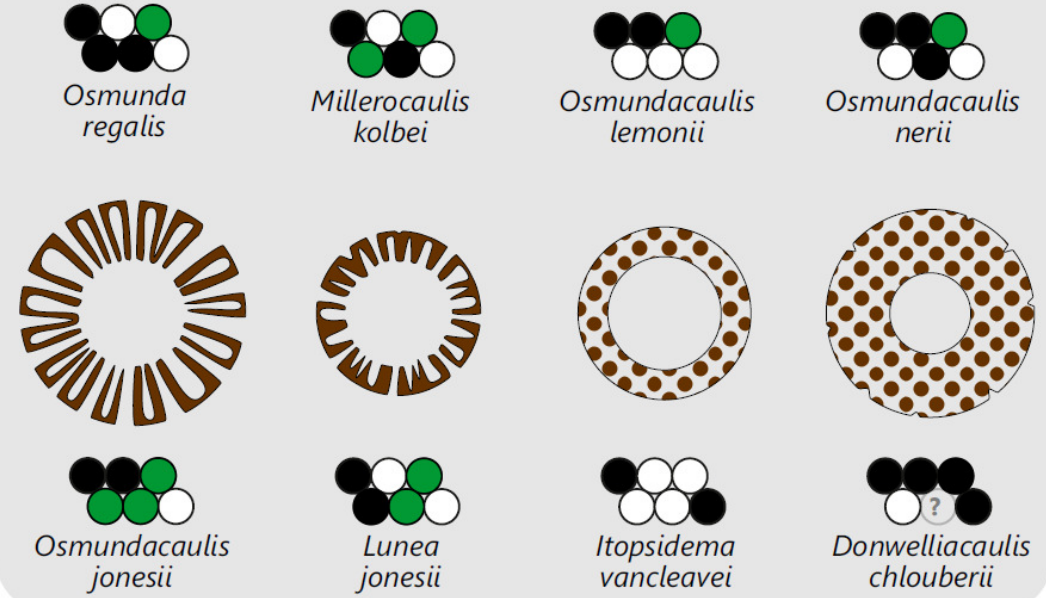

2755 Figure 3. Diagram showing selected examples of the wide variety of modifications of the stelar

2756 xylem siphon in osmundalean stems as seen in cross-section through the stele, together with the

2757 respective character scoring used in the matrix (for definition of characters and of character

2758 states see text). 
Figure 4

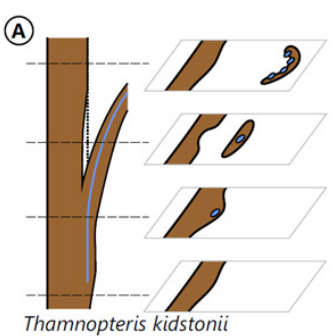

(E)

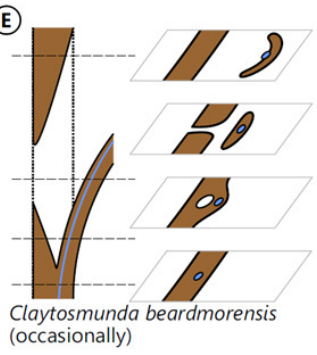

(B)

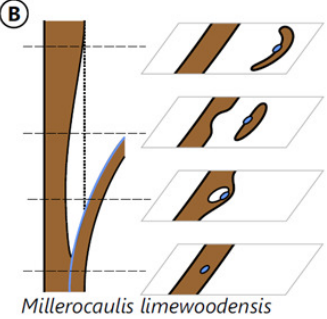

(F)

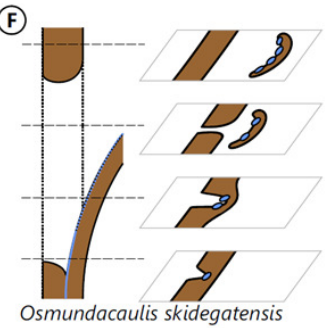

(c)

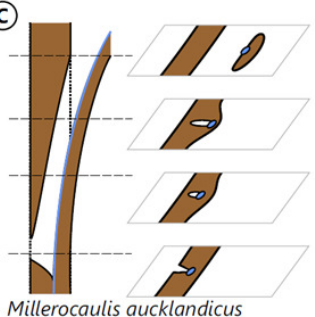

(a)

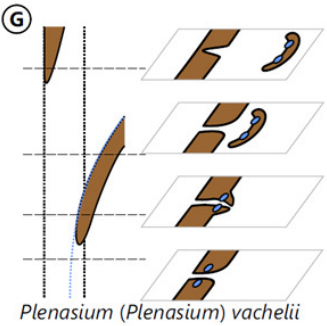

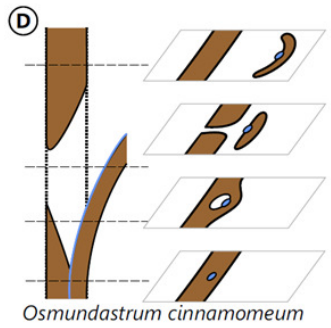

$(\oplus$

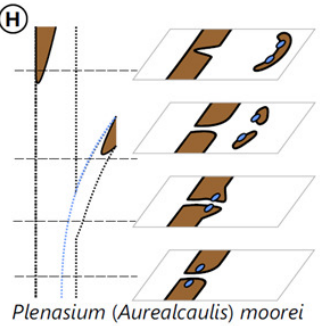

2762

2763 Figure 4. Diagram illustrating different modes of leaf-trace formation in selected types of

2764 osmundalean stems, each showing a stem radial section through the center of the developing

2765 trace and the resulting aspects of four successive cross-sections. Metaxylem in brown;

2766 protoxylem strands in blue. 
Figure 5

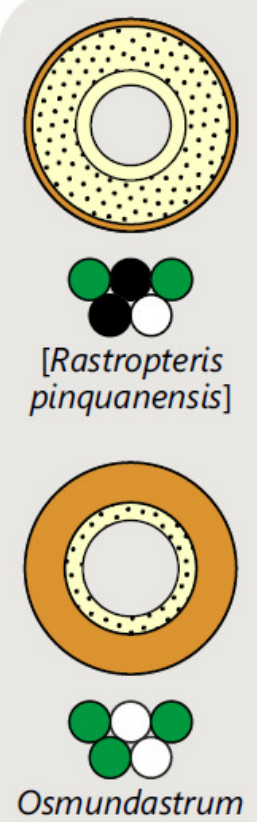

cinnamomeum


Guairea carnierii
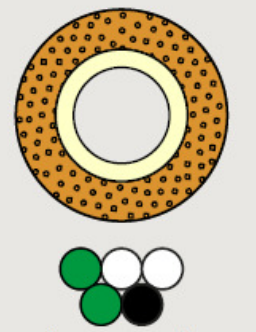

Leptopteris superba

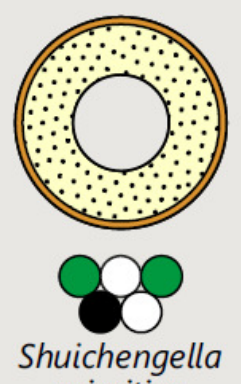
primitiva

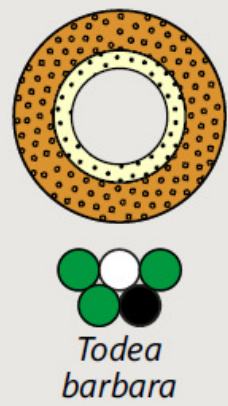

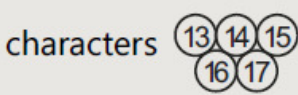

coding (0)12)

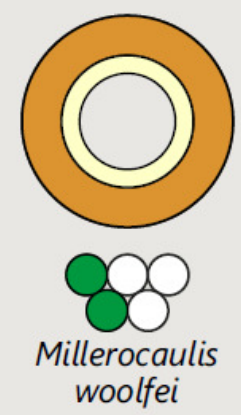

2769 Figure 5. Diagram illustrating selected examples for different layering and composition of

2770 cortical tissues in osmundalean stems as seen in stem cross-section, together with the respective

2771 character scoring used in the matrix (for definition of characters and of character states see text).

2772 Parenchyma in pale yellow; sclerenchyma in light brown; thicker-walled fibre patches as black

2773 stipples or rings. 
Figure 6

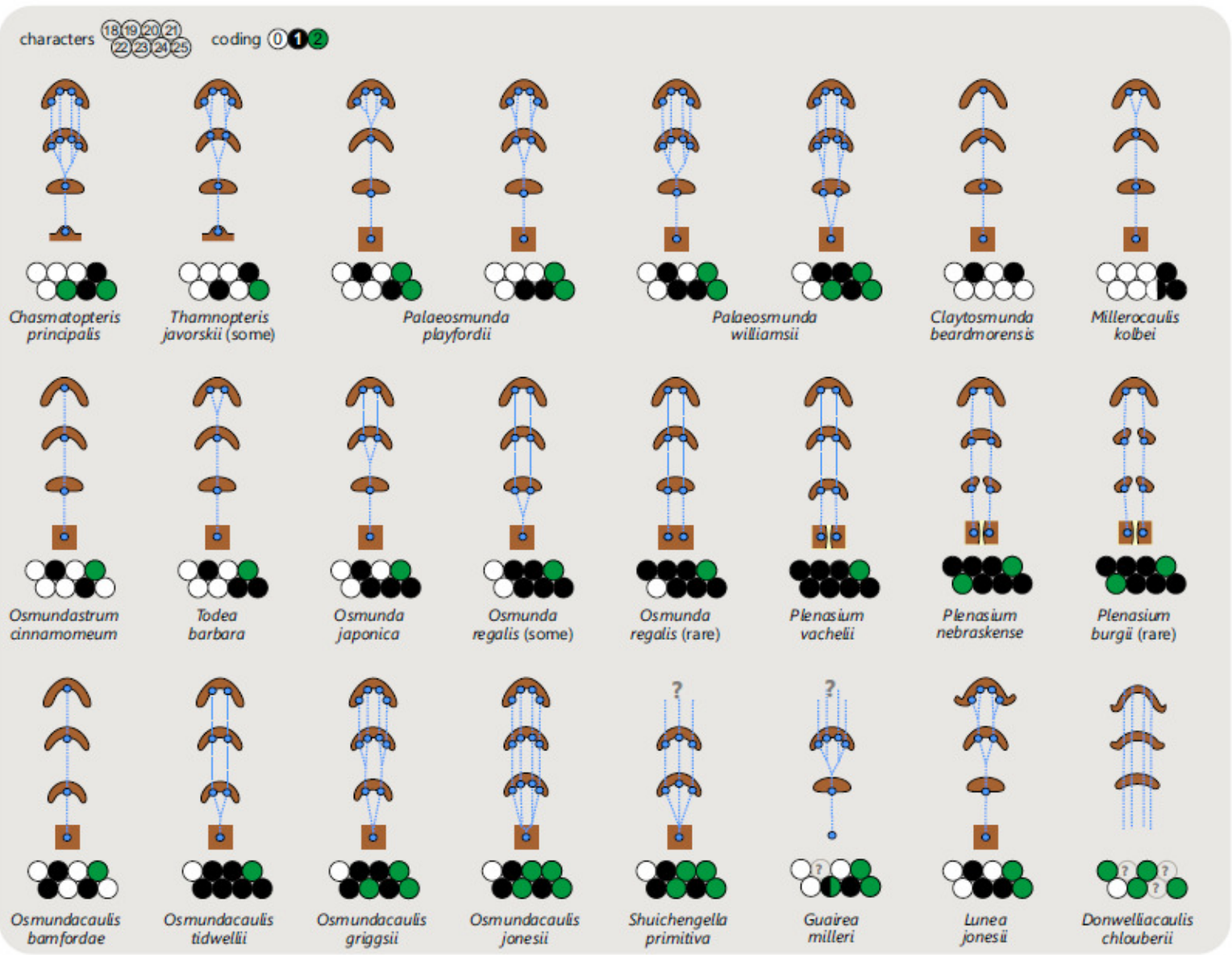

Figure 6. Diagram illustrating selected examples for different modes of leaf-trace formation and

2777 development in osmundalean stems each in the form of four simplified aspects of successive

2778 cross-sections (at the level of the stele, upon departure from the stele, mid-way through the

2779 cortex, and upon departure from the stem), together with the respective character scoring used in

2780 the matrix (for detailed explanation and for definition of characters and of character states see

2781 text). Metaxylem in brown; protoxylem strands in blue; parenchyma in pale yellow. 
Figure 7
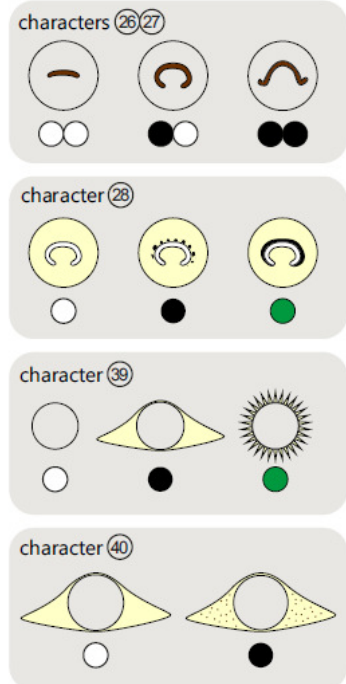
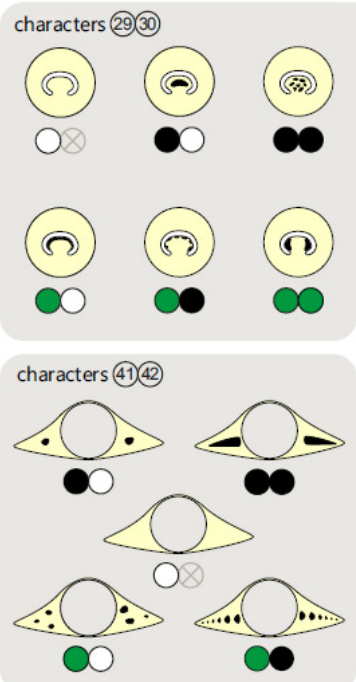
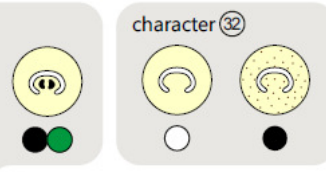

characters (35) (36) (37) 38
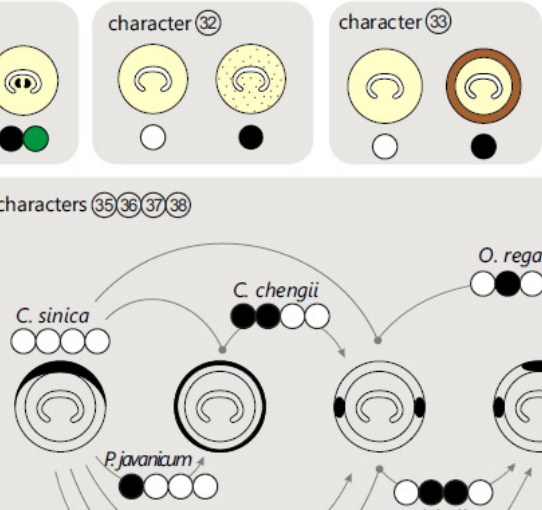

character (34)

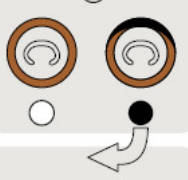

c. claytoniana

O. cinnamomeum 000

coding (0) 12

2784 Figure 7. Diagram illustrating selected anatomical features of the stipes of Osmundales together

2785 with the respective character scoring used in the matrix (for detailed explanation and for

2786 definition of characters and of character states see text). Metaxylem (characters 26 and 27) in

2787 dark brown; parenchyma in pale yellow; sclerenchyma in brown; scattered isolated sclereids

2788 (characters 32 and 40) indicated as brown stipples; patches or clusters of particularly thick-

2789 walled fibres in black. 


\section{Figure 8}
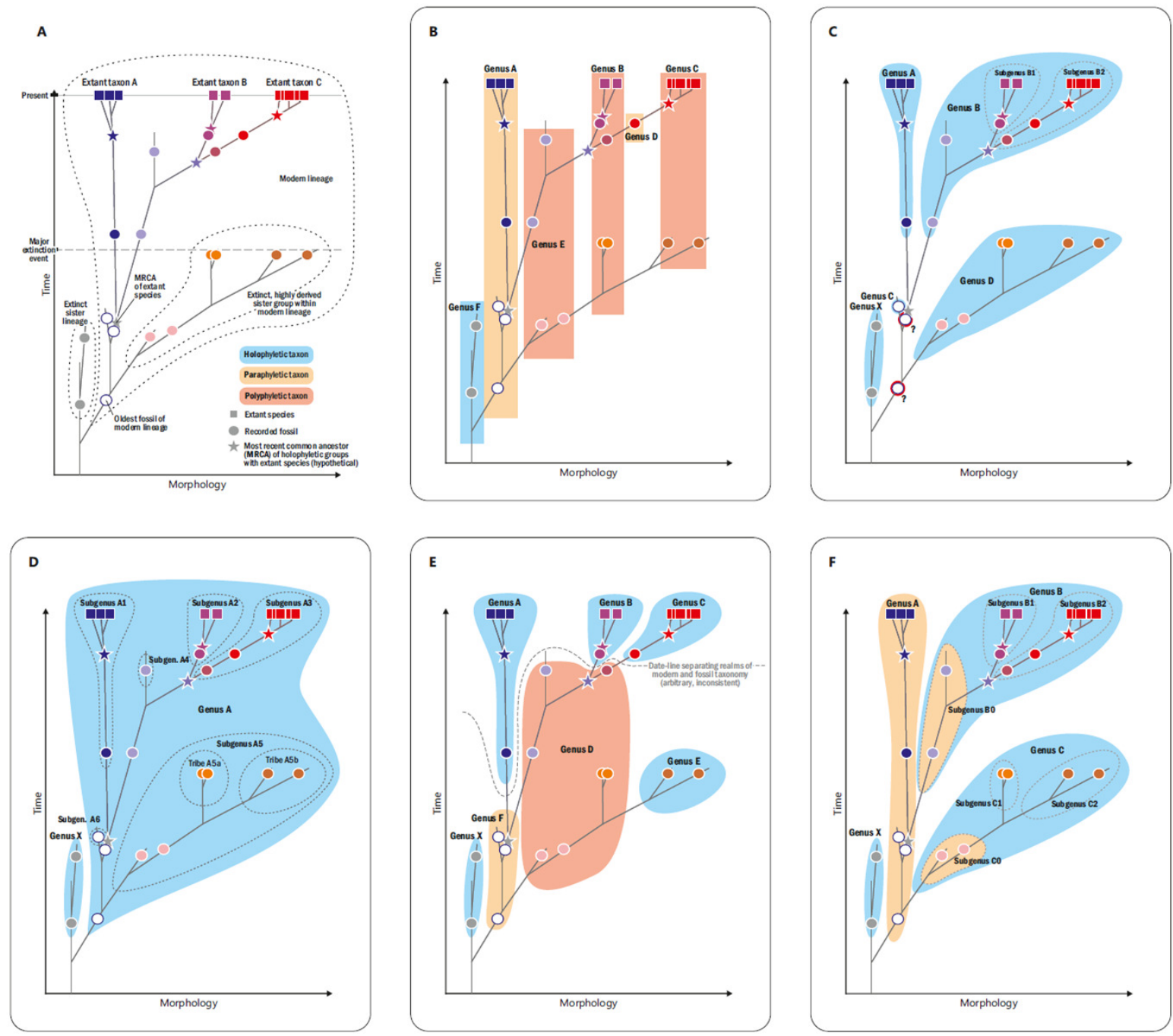

2792 Figure 8. Diagram illustrating different naming concepts (classifications) for extinct and extant

2793 representatives of a phylogenetic lineage. $\mathbf{A}=$ a hypothetical phylogeny of three extant genera

2794 (taxa A, B, and C) and their fossil relatives including actual ancestors and extinct sister lineages;

$2795 \mathbf{B}=$ a traditional phenetic classification, in which all species that share a similar morphology

2796 (morphospace) are classified together regardless of their phylogenetic relationship; note that the

2797 resulting genera can thus be para- or polyphyletic; $\mathbf{C}=$ an incomprehensive cladistic

2798 classification accepting only holophyletic taxa; note that one fossil has to be accommodated in its

2799 own genus and that two other fossils (members of the lineage ancestral of Genera A-B and 
2800 Genera A-D respectively) must be excluded ('gen. indet.') to avoid violation of the principle; D

$2801=$ comprehensive cladistic classification accepting only holophyletic taxa; the problem of

2802 unclassifiable fossils is avoided by including all fossils and extant species of the modern lineage

2803 in one large genus and by introducing lower taxon ranks to distinguish holophyletic (sub)groups;

$2804 \mathbf{E}=$ a phenetic-cladistic 'hybrid' classification common in palaeontology in which selected

2805 fossils are assigned to extant genera, whereas others are assigned to artificial taxa ('parataxa',

2806 'fossil taxa', formerly 'form taxa' or 'morphotaxa') in order to maintain holophyly of extant

2807 taxa; note that an arbitrary and inconsistent date-line separates the realms of modern taxonomy

2808 and fossil taxonomy, and that fossils can effectively build up paraphyletic or polyphyletic taxa; F

$2809=$ evolutionary classification in which paraphyletic taxa are accepted as valid taxonomic units;

2810 note that the resulting classification takes phylogenetic history into account and at the same time

2811 produces only monophyletic taxa that can be diagnosed by a distinct morphology; potential new

2812 fossils can be easily incorporated and nomenclatural stability is maintained; taxa are informative;

2813 and inflationary numbers of single-specimen taxa or of taxonomic ranks are avoided. 


\section{Figure 9}

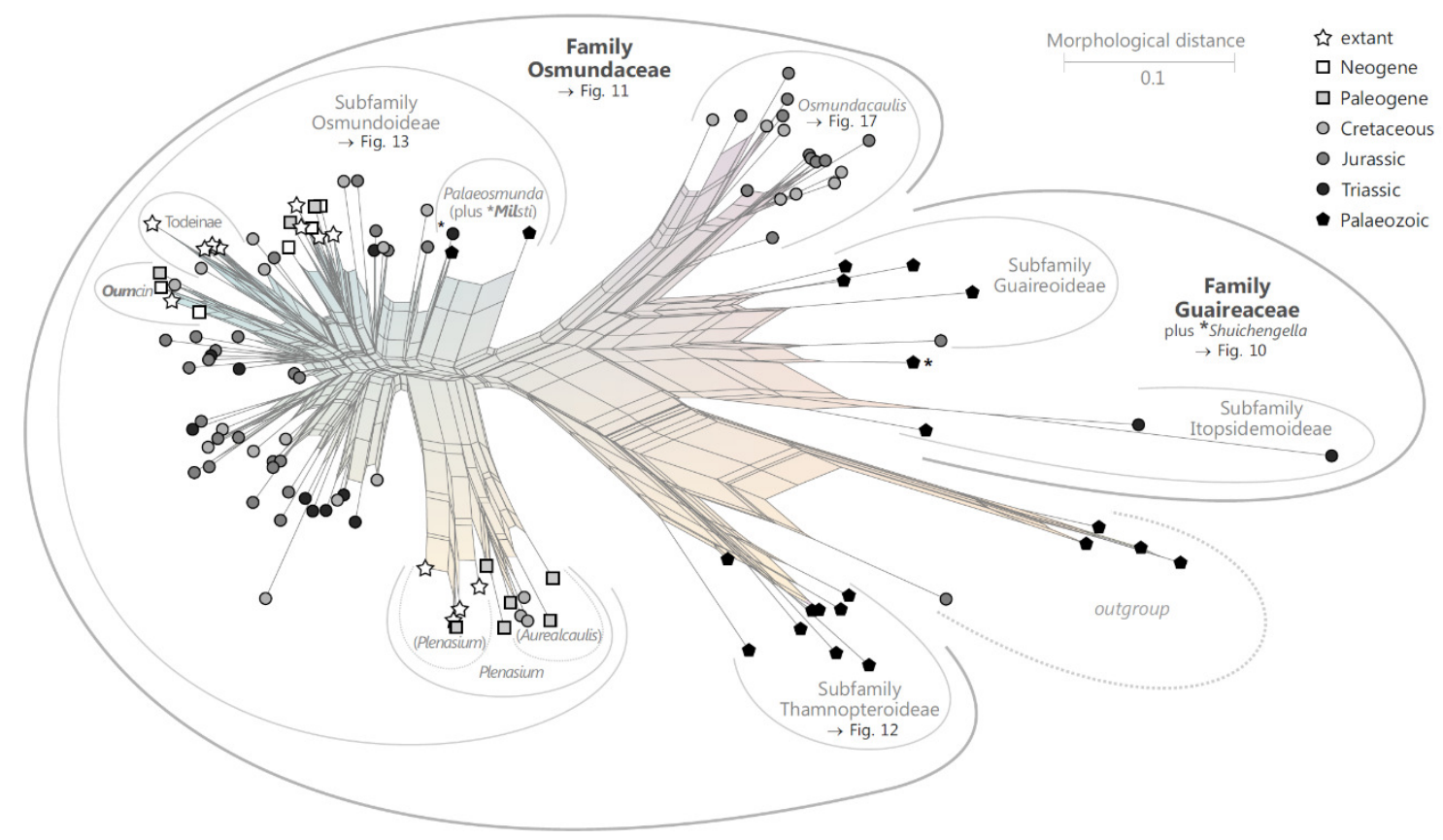

2816 Figure 9. Planar phylogenetic network (neighbour-net) for all operational units of order

2817 Osmundales except those with $>60 \%$ characters missing. Note that the currently accepted family 2818 and subfamily concept is well supported with the exception of the Osmundacaulis lineage. The

2819 six-letter labels are contractions of the taxon name of an operational unit formed from the first

2820 three letters of the genus name in bold followed by the first three letters of the specific epithet;

2821 Oum $=$ Osmundastrum. A fully labelled raw version of this graph is provided in the

2822 Supplemental Materials (Supplemental Figure S3). 


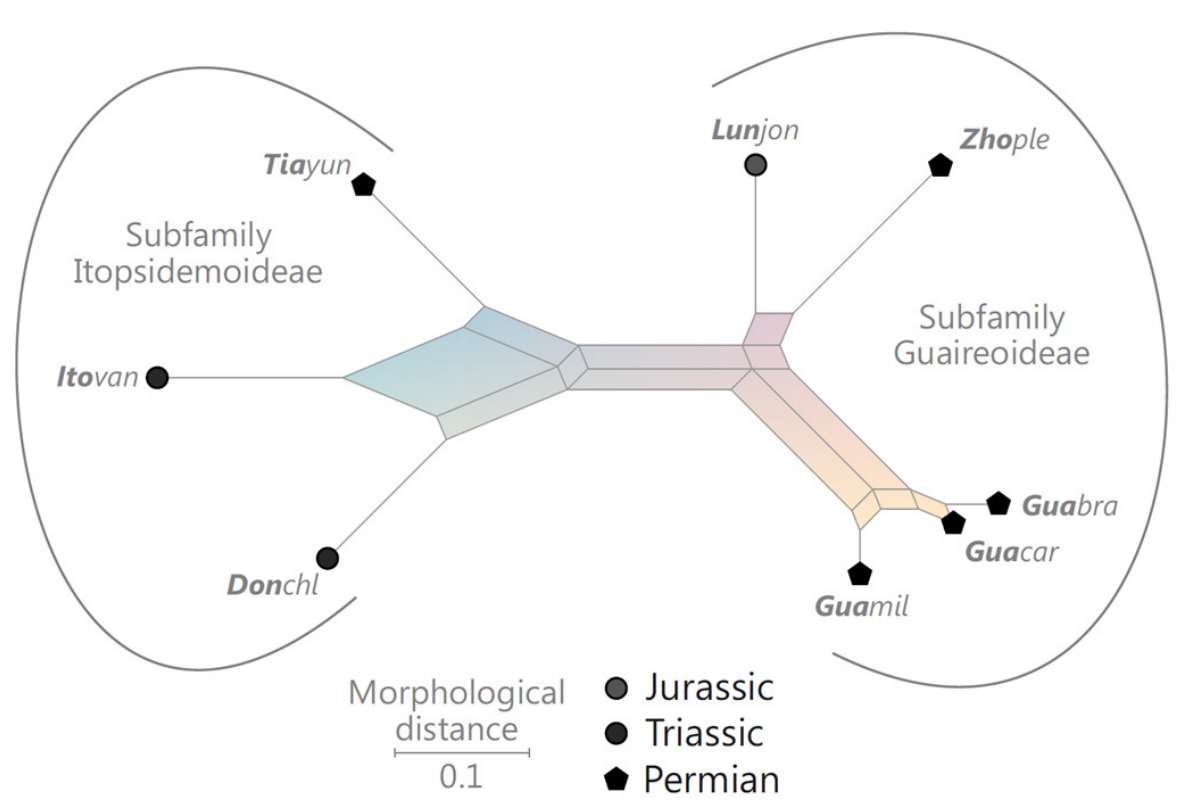

2825 Figure 10. Planar phylogenetic network (neighbour-net) for all operational units of family

2826 Guaireaceae. The six-letter labels are contractions of the taxon name of an operational unit

2827 formed from the first three letters of the genus name in bold followed by the first three letters of

2828 the specific epithet. A fully labelled raw version of this graph is provided in the Supplemental

2829 Files. 


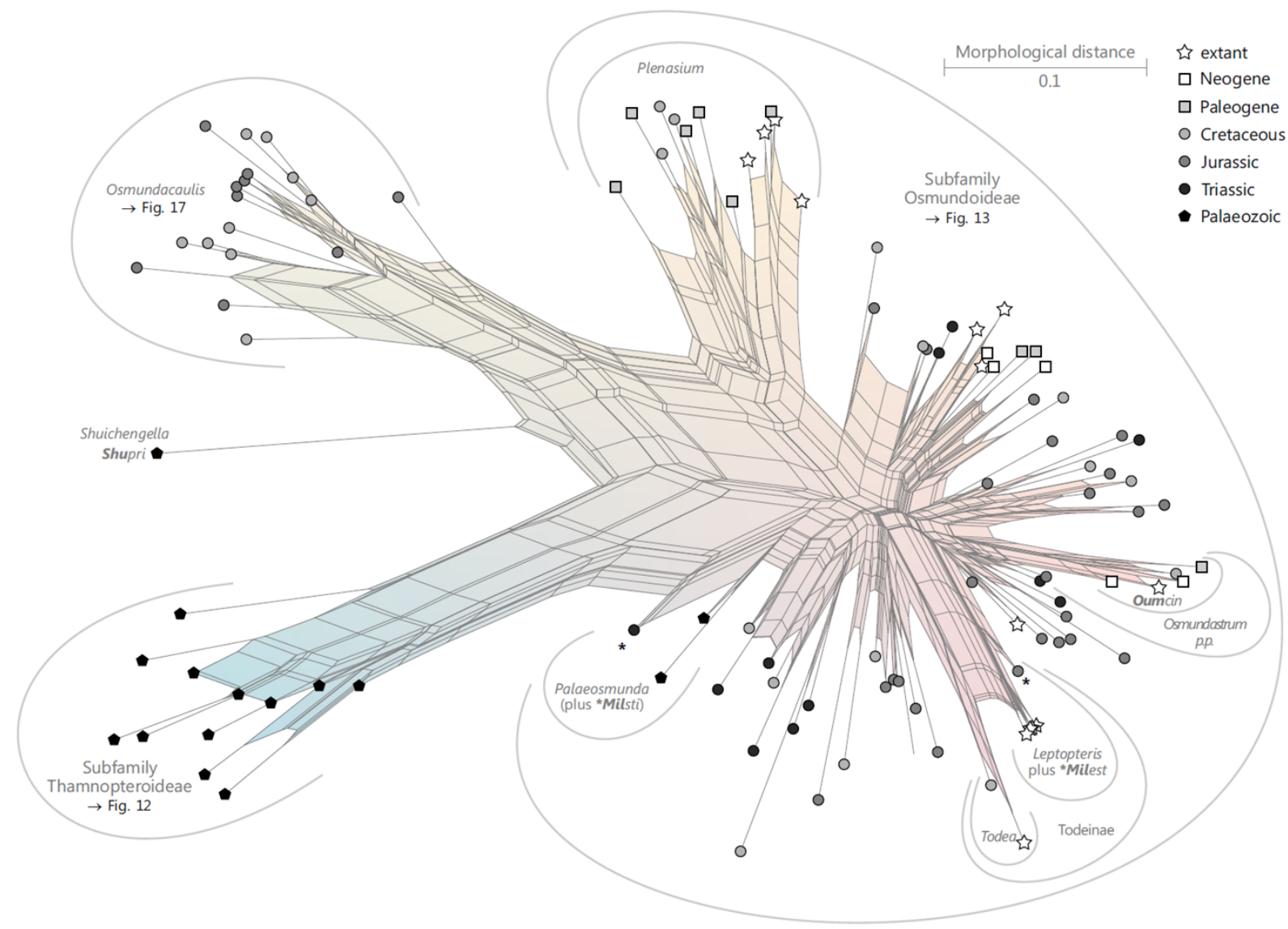

2832 Figure 11. Planar phylogenetic network (neighbour-net) for all operational units of family

2833 Osmundaceae. Note the two well-resolved branches for subfamily Thamnopteroideae and for

2834 Osmundacaulis; attachment of the isolated Shuichengella near the base of the Osmundacaulis

2835 branch; the box comprising Palaeosmunda plus Millerocaulis stipabonettiorum between

2836 Thamnopteroideae and the remaining Osmundoideae; the clustering of modern genera and of

2837 subgenera with extant representatives; and the poorly resolved spider-web structure of the 2838 remaining Mesozoic fossil Osmundinae and Millerocaulis species. The six-letter labels are 2839 contractions of the taxon name of an operational unit formed from the first three letters of the 2840 genus name in bold followed by the first three letters of the specific epithet; Oum = 
2841 Osmundastrum. A fully labelled raw version of this graph is provided in the Supplemental Files 2842 (Supplemental Figure S4). 


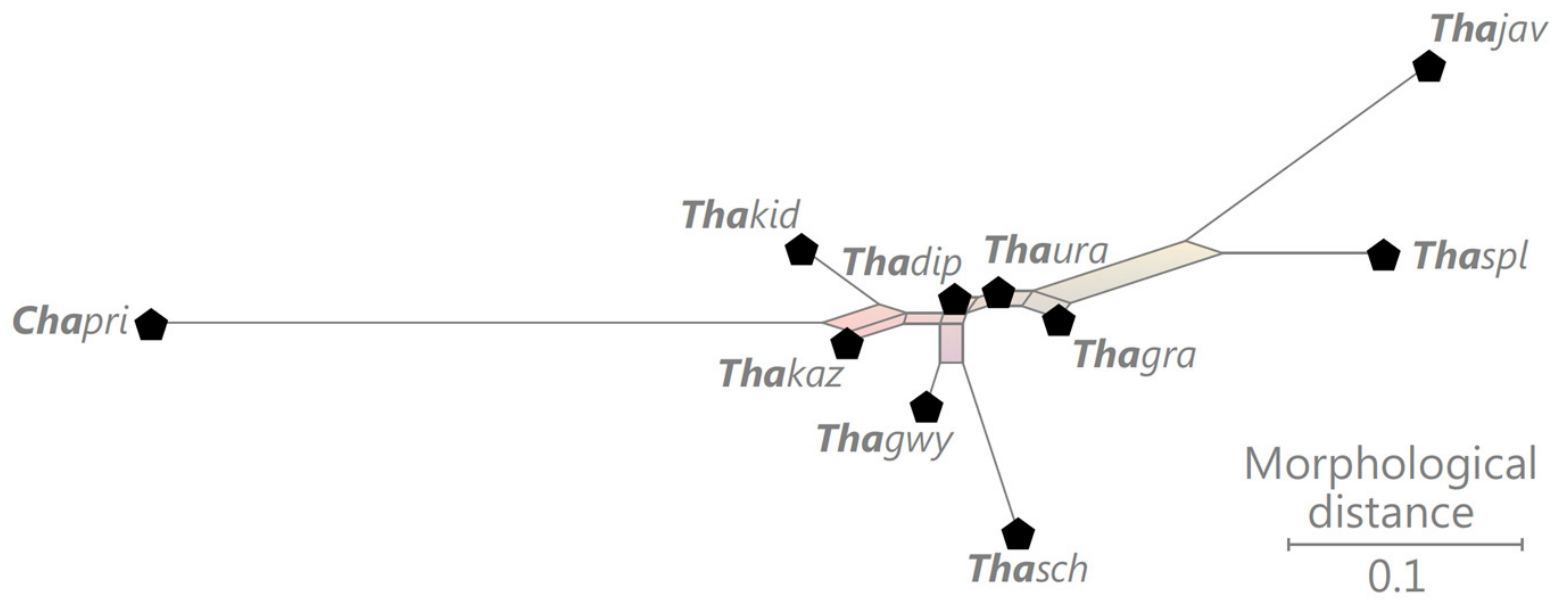

2845 Figure 12. Planar phylogenetic network (neighbour-net) for all operational units of subfamily 2846 Thamnopteroideae (Osmundaceae). Note the clustering especially of species of the formerly 2847 separated Thamnopteris and Zalesskya in the center of the net and the relatively wide divergence 2848 of Chasmatopteris principalis. The six-letter labels are contractions of the taxon name of an 2849 operational unit formed from the first three letters of the genus name in bold followed by the first 2850 three letters of the specific epithet. 


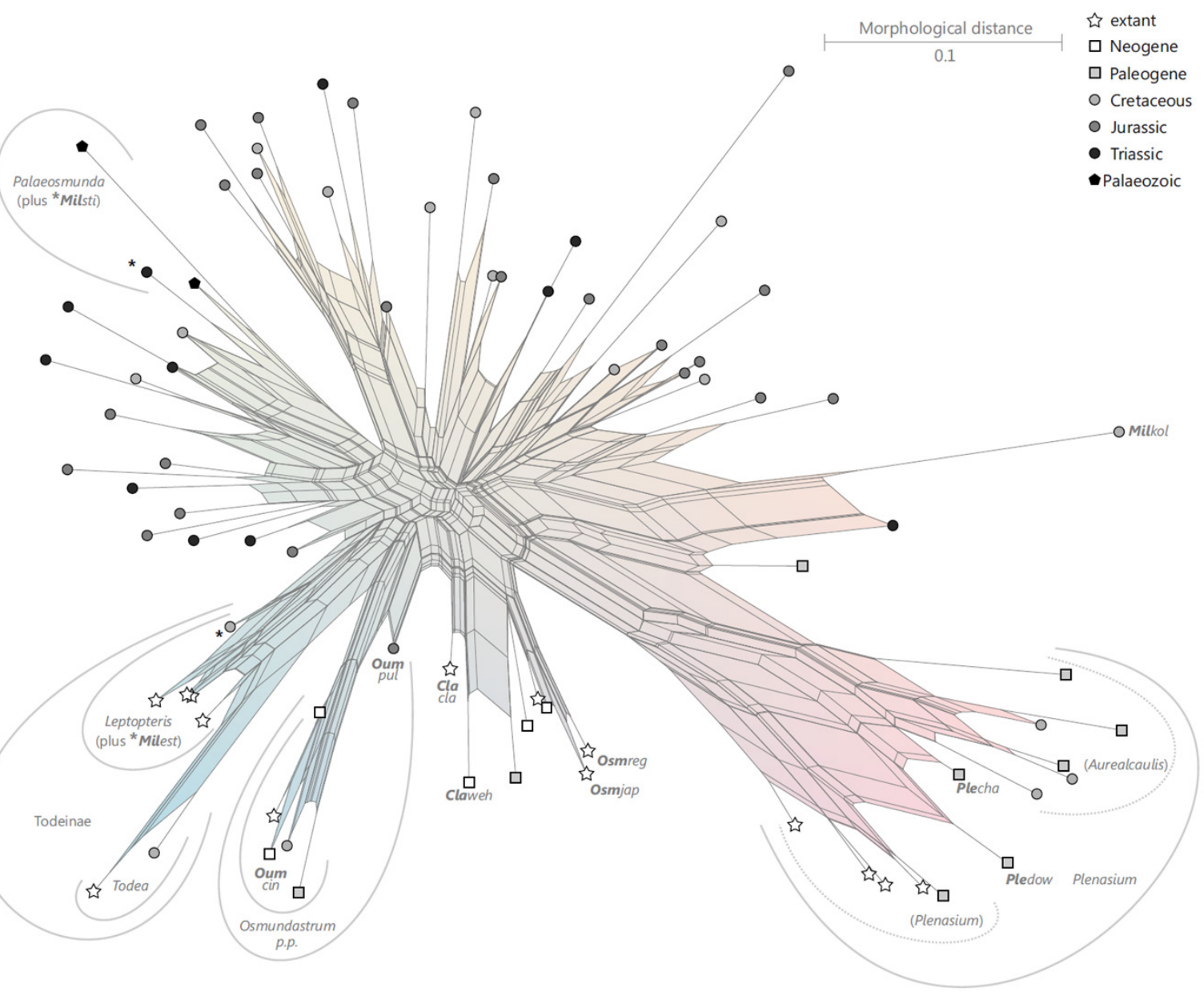

2853 Figure 13. Planar phylogenetic network (neighbour-net) for all operational units of subfamily

2854 Osmundoideae (Osmundaceae). Note the divergence of the branch comprising the closely similar

2855 subgenera Plenasium and Aurealcaulis and the separation of the branch containing Todea and Leptopteris, including 'Millerocaulis estipularis'. The six-letter labels are contractions of the

2857 taxon name of an operational unit formed from the first three letters of the genus name in bold 2858 followed by the first three letters of the specific epithet; Oum = Osmundastrum. A fully labelled 2859 raw version of this graph is provided in the Supplemental Files (Supplemental Figure S5). 


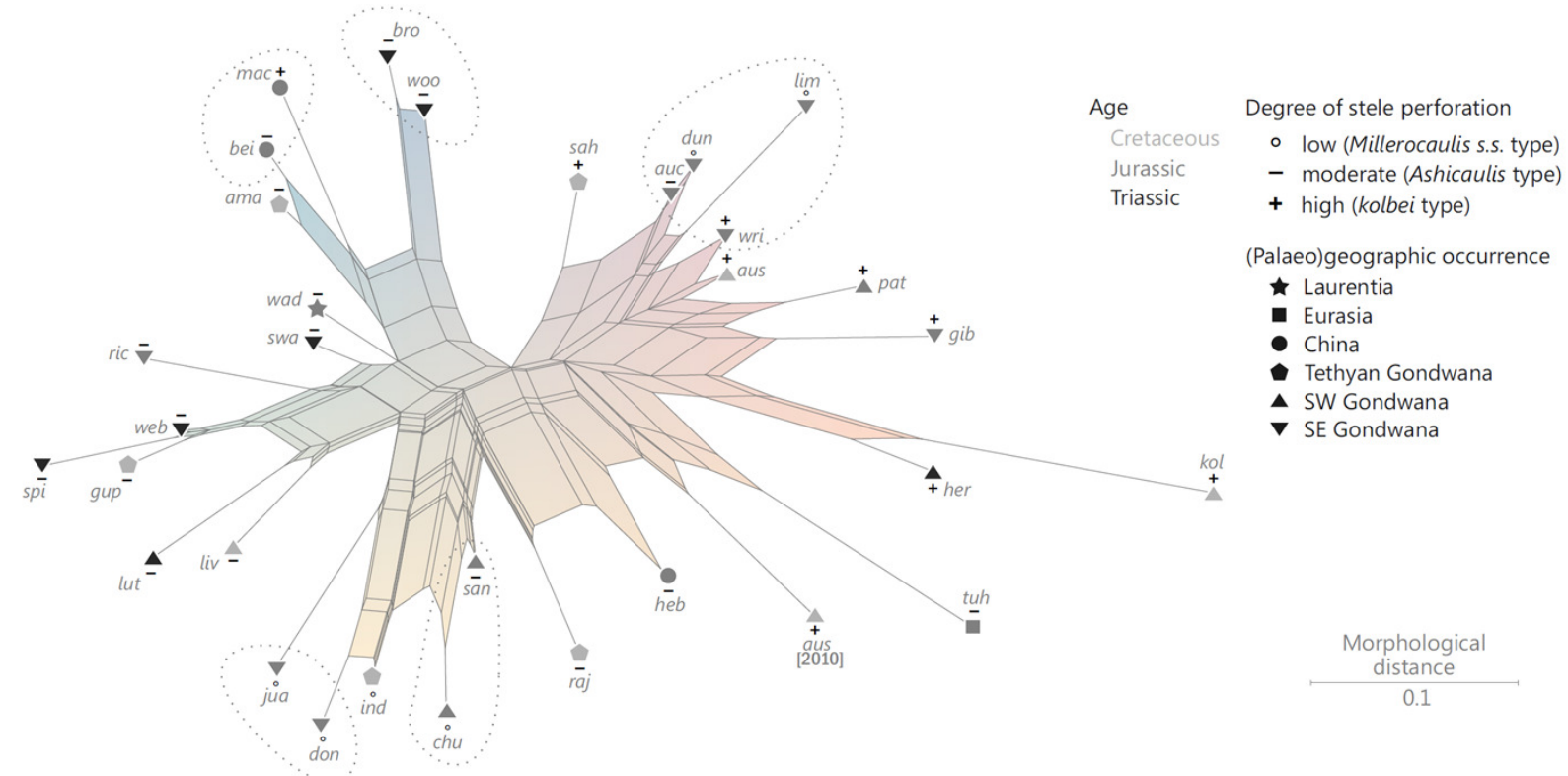

2861

2862 Figure 14. Planar phylogenetic network (neighbour-net) for all operational units of genus

2863 Millerocaulis (Osmundaceae, Osmundoideae). Note the poorly resolved spider-web structure of 2864 the net and the conspicuous close placements of several taxa from similar-aged deposits in

2865 similar geographic realms (see text for details). The six-letter labels are contractions of the taxon 2866 name of an operational unit formed from the first three letters of the genus name in bold 2867 followed by the first three letters of the specific epithet. 


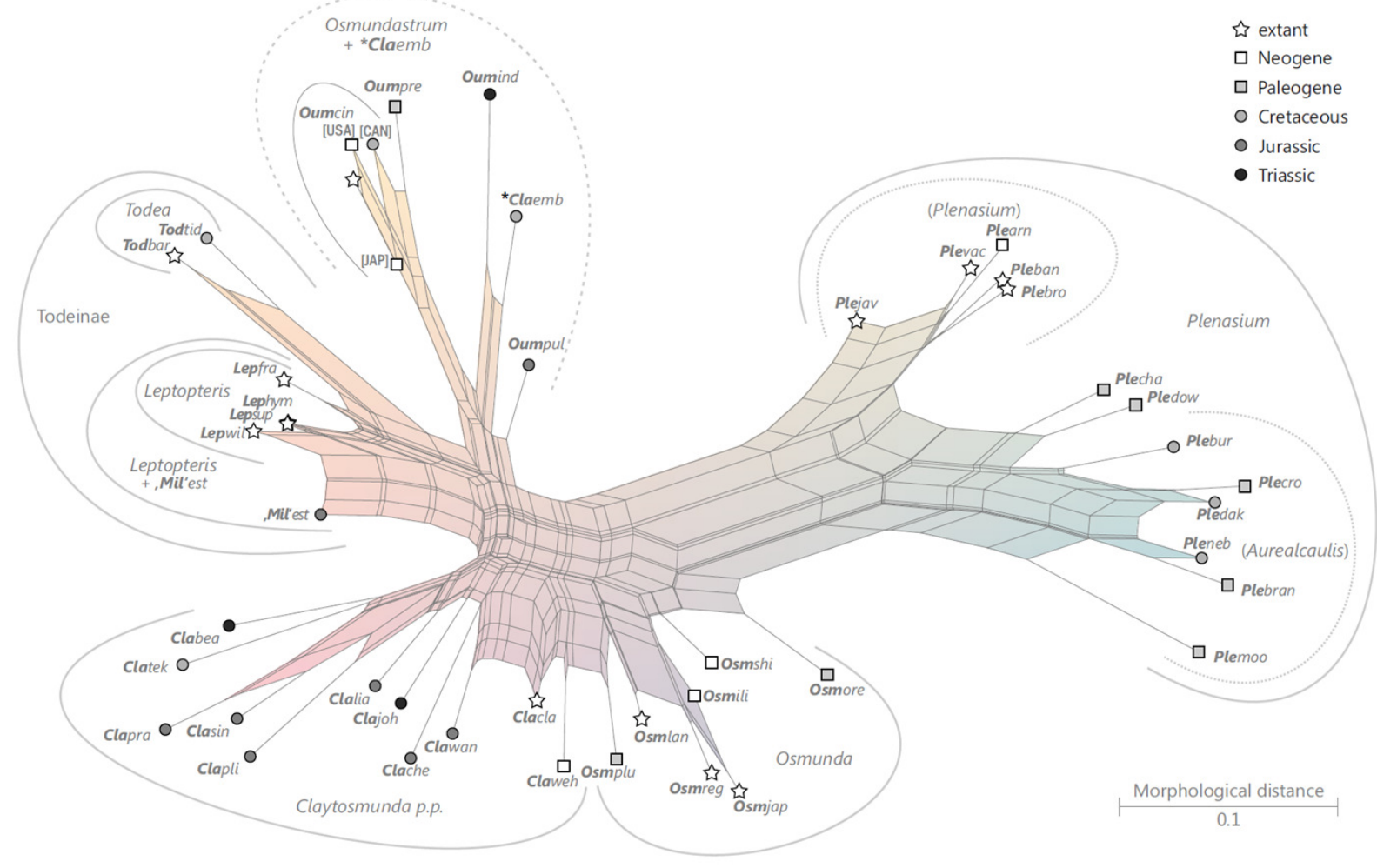

2870 Figure 15. Planar phylogenetic network (neighbour-net) for all operational units of tribe

2871 Osmundeae (containing those Osmundaceae genera with extant species). Note the divergence of

2872 the branch comprising the subgenera Plenasium and Aurealcaulis; the divergence of subgenus

2873 Aurealcaulis; the separation of a branch containing Todea and Leptopteris, including

2874 'Millerocaulis estipularis'; and the consistent placement of the oldest (Triassic to Jurassic)

2875 fossils between the younger members of Osmundastrum and Claytosmunda. The six-letter labels

2876 are contractions of the taxon name of an operational unit formed from the first three letters of the 2877 genus name in bold followed by the first three letters of the specific epithet; Oum = Osmundastrum. 


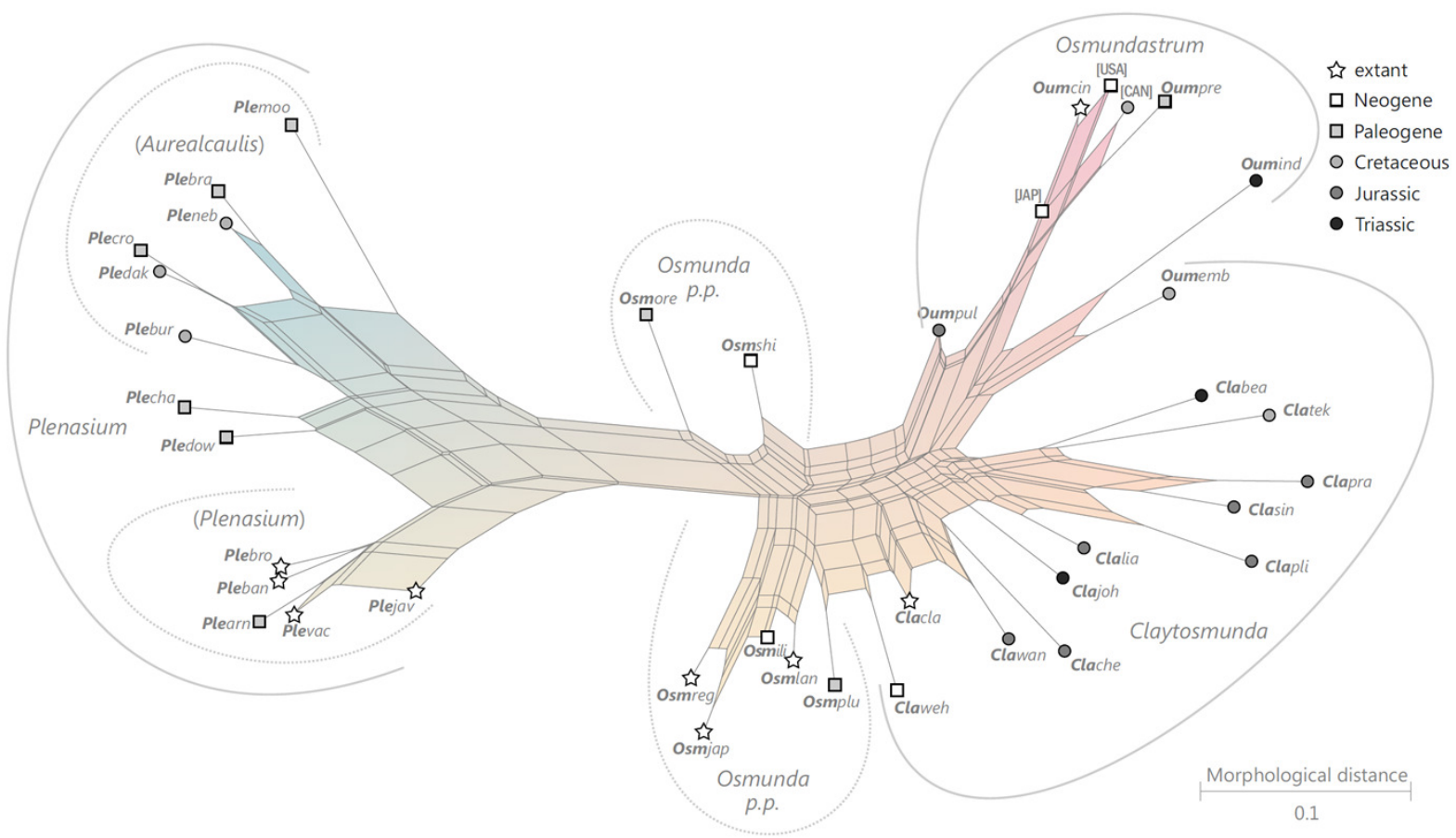

2880

2881 Figure 16. Planar phylogenetic network (neighbour-net) for all operational units of subtribe

2882 Osmundinae (Osmundaceae, Osmundoideae, Osmundeae). Note the divergence of the branch comprising the closely similar subgenera Plenasium and Aurealcaulis out from the center of the

2884 box comprising Osmunda; the divergence of subgenus Aurealcaulis; the separation of a branch

2885 containing Todea and Leptopteris, including 'Millerocaulis estipularis'; and the consistent

2886 placement of all Mesozoic fossils between the younger members of Osmundastrum and

2887 Claytosmunda. The six-letter labels are contractions of the taxon name of an operational unit

2888 formed from the first three letters of the genus name in bold followed by the first three letters of

2889 the specific epithet; Oum = Osmundastrum. 
Figure 17

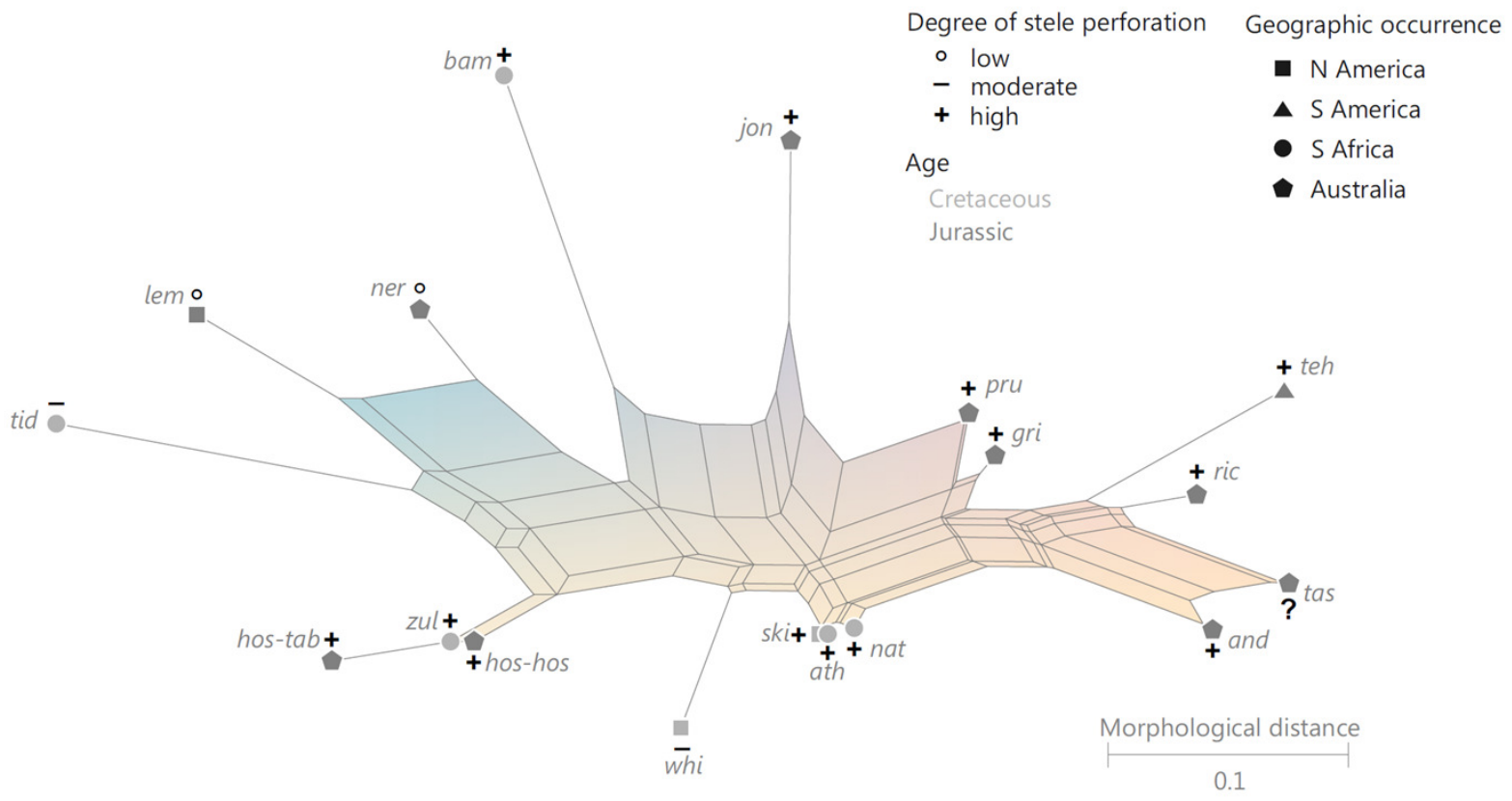

2892 Figure 17. Planar phylogenetic network (neighbour-net) for all operational units of genus

2893 Osmundacaulis (subfamily incertae sedis, Osmundaceae). The three-letter labels indicate the 2894 first three letters of the specific epithet of the relevant taxon. 


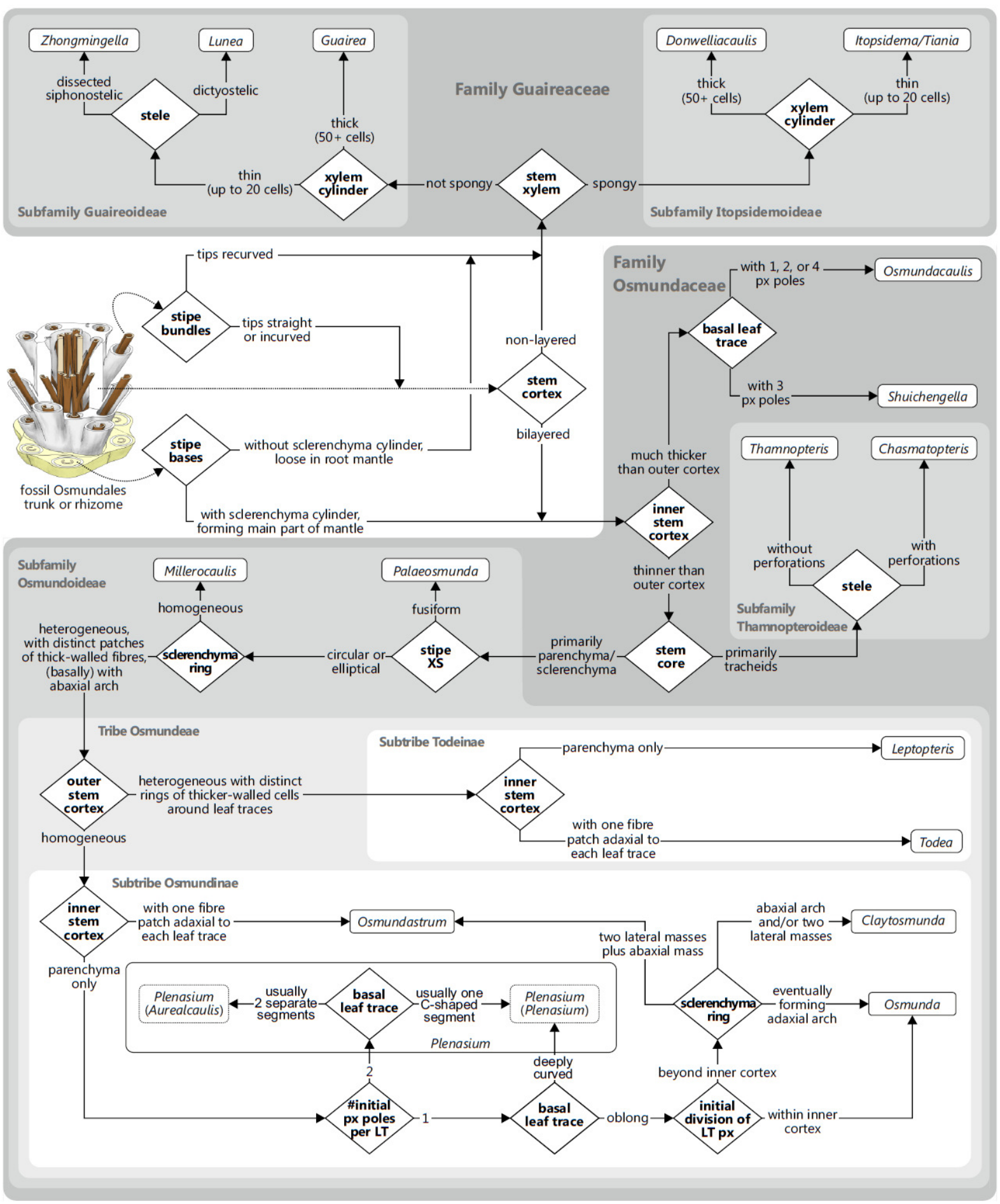


2897 Figure 18. Polytomous key illustrating possible ways for straightforward identification and

2898 classification of structurally preserved axes of Osmundales according to diagnostic anatomical 2899 features. 

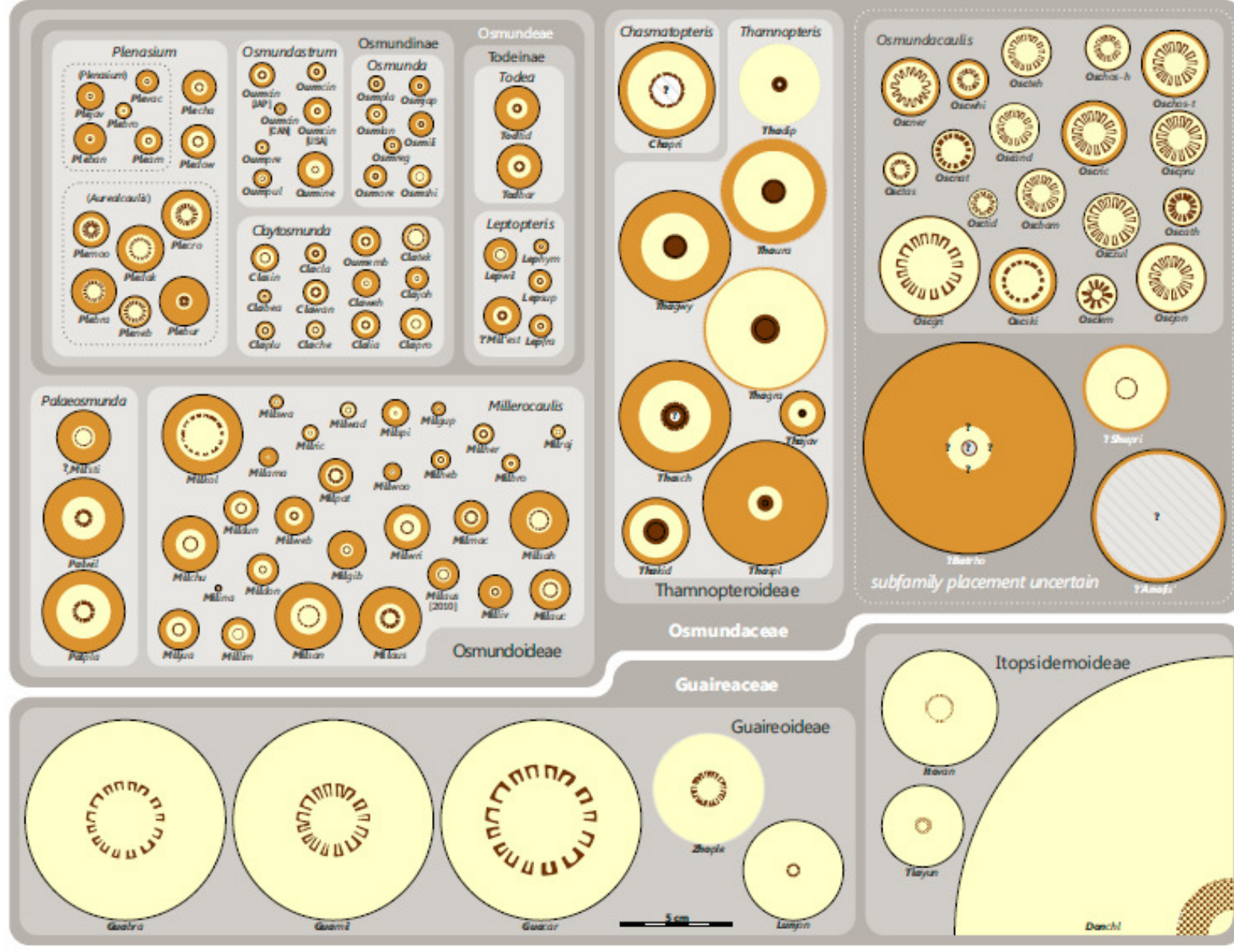

2901

2902 Figure 19. Overview diagram illustrating the diversity and disparity of osmundalean stems

2903 arranged according to the taxonomic revision proposed here. Each circular diagram represents a

2904 simplified stem cross-section of the relevant species that gives basic information on the structure

2905 and proportional sizes of the stem core, xylem siphon, cortex or cortical layers and the entire

2906 stem excluding the mantle, all to the same scale. Taxon names are given in the form of six-letter

2907 labels that are contractions formed from the three first letters of the genus name in bold followed

2908 by the first three letters of the specific epithet; Oum = Osmundastrum. Primarily parenchymatic

2909 tissues in pale yellow; stelar metaxylem in dark brown; sclerenchyma in light brown; note that 
2910 individual fibres or fibre patches in pith or cortical tissues are omitted. A large-format, high-

2911 resolution version of this image is provided in the Supplemental Files (Supplemental Figure S6). 


\section{Tables}

2913 Table 1. Potential sister species within Millerocaulis as inferred via non-parametric

2914 bootstrapping of the Millerocaulis-matrix (matrix dimensions 33 taxa, 23 variable characters).

2915 Only pairs are shown, where the corresponding split received BS support $>33$ under at least one

2916 optimality criterion (i.e. approximately one-third or more of the scored characters support such a

2917 split). Abbreviations: AllOther = range with respect to any other taxon in the matrix

2918 ('Millerocaulis' stipabonettiorum, see above, not considered); IND = India; K = Cretaceous;

2919 CHI $=$ China; $\mathrm{J}=$ Jurassic; AUS $=$ Australia; $\mathrm{T}=$ Triassic; ANT $=$ Antarctica; NZ $=$ New

2920 Zealand; ARG = Argentina; SAF = South Africa; co-occurrence in bold.

2921

Pair

Provenance

Pairwise

BS support

distance

M. amarjolensis + M. beipiaoensis

M. broganii + M. woolfei

Pair AllOther ML LS MP

M. dunlopii + M. aucklandicus

IND (K) + CHI (J)

0.06

$M$. indicus $+M$. donponii

AUS (T) + ANT (T)

$0.14-0.61 \quad 31$

NZ (J) + NZ (J)

$\begin{array}{llll}0.17-0.50 & 94 \quad 87 & 68\end{array}$

M. hebeiensis + M. rajmahalensis

IND (K) + AUS (J)

$0.11-0.47 \quad 42 \quad 42 \quad 12$

M. herbstii + M. kolbii

CHI (J) + IND (K)

0.06

$\operatorname{ARG}(\mathrm{J})+\mathrm{SAF}(\mathrm{K})$

0.15

$0.17-0.67$

57

M. spinksii + M. websteri

AUS (?T) + AUS (?T)

0.23

$0.13-0.60 \quad 30 \quad 37 \quad 28$

2922 
2923 Table 2. Tabulation of values regarding relationships within the Todeinae and the placement of

2924 the two fossil members of the subtribe. All values are based on the Osmundeae-only-matrix;

2925 asterisks denote splits that are in conflict with molecular data. Note: All other competing splits

2926 received $\mathrm{BS}_{\mathrm{ML} / \mathrm{LS} / \mathrm{MP}}<10$.

2927

\begin{tabular}{lllllll}
$\begin{array}{l}\text { Split (clade in an accordingly } \\
\text { rooted tree) }\end{array}$ & \multicolumn{2}{l}{ Pairwise distance } & & BS support \\
& Internal & External & & ML & LS & MP \\
& & Todeinae & Other & & & \\
\hline Todeinae & $0-0.26$ & N/A & $0.10-0.63$ & 46 & 75 & $<10$ \\
Leptopteris (incl. ?L. estipularis) & $0-0.15$ & $0.14-0.26$ & $0.10-0.57$ & $<10$ & 11 & 13 \\
?. estipularis + L. wilkesiana & 0.05 & $0.03-0.26$ & $0.10-0.57$ & 34 & 25 & 20 \\
Extant Leptopteris + Todea & $0-0.24$ & $0.05-0.26$ & $0.17-0.63$ & 21 & 27 & 16 \\
Extant Leptopteris & $0-0.10$ & $0.14-0.24$ & $0.10-0.57$ & $<10$ & 26 & 16 \\
L. fraseri + Todea* & $0.10-0.23$ & $0.07-0.26$ & $0.19-0.63$ & 44 & 25 & 13 \\
L. fraseri + T. barbara* & 0.14 & $0.10-0.25$ & $0.19-0.63$ & 15 & 10 & 13 \\
T. tidwellii + T. barbara & 0.10 & $0.19-0.26$ & $0.24-0.63$ & 72 & 75 & 52 \\
\hline
\end{tabular}


2929 Table 3. Tabulation of values regarding potential relationships of pre-Cretaceous fossils treated

2930 here as members of the Osmundastrum-lineage.

\begin{tabular}{|c|c|c|c|c|c|c|c|c|c|c|}
\hline \multirow{2}{*}{$\begin{array}{l}\text { Split; } \\
\text { (alternative) clade } \\
\text { in an accordingly } \\
\text { rooted tree }\end{array}$} & & \multicolumn{3}{|c|}{$\begin{array}{l}\text { Pairwise distance } \\
\text { (matrix S08) }\end{array}$} & \multicolumn{3}{|c|}{$\begin{array}{l}\text { BS support } \\
\text { Matrix S08 }\end{array}$} & \multicolumn{3}{|c|}{ Matrix S09 } \\
\hline & & $\begin{array}{l}\text { Within } \\
\text { (pot.) }\end{array}$ & $\begin{array}{l}\text { To extant } O \text {. } \\
\text { cinnamomeum }\end{array}$ & $\begin{array}{l}\text { To extant } C \text {. } \\
\text { claytoniana }\end{array}$ & ML & LS & MP & ML & LS & MP \\
\hline $\begin{array}{l}\text { Osmundastrum } \\
\text { cinnamomeum }\end{array}$ & $\begin{array}{l}\text { Cretaceous } \\
\text { onwards }\end{array}$ & $\begin{array}{l}0.03- \\
0.10\end{array}$ & $0.03-0.10$ & $0.15-0.30$ & $<10$ & 16 & $<10$ & $<10$ & 18 & $<10$ \\
\hline $\begin{array}{l}\text { O. cinnamomeum } \\
\text { (Cretaceous, } \\
\text { Canada) }+ \text { O. } \\
\text { precinnamomeum }\end{array}$ & & 0.07 & $0.10 / 0.17$ & $0.23 / 0.23$ & 60 & 59 & 33 & 65 & 59 & 38 \\
\hline $\begin{array}{l}\text { O. cinnamomeum } \\
+O . \\
\text { precinnamomeum }\end{array}$ & $\begin{array}{l}\text { Cretaceous } \\
\text { onwards }\end{array}$ & $\begin{array}{l}0.03- \\
0.17\end{array}$ & $0.03-0.17$ & $0.15-0.30$ & 57 & 51 & 16 & 56 & 65 & 17 \\
\hline $\begin{array}{l}\text { O. pulchellum }+O . \\
\text { (pre) } \text { cinnamomeum }\end{array}$ & $\begin{array}{l}\text { Jurassic } \\
\text { onwards }\end{array}$ & $\begin{array}{l}0.03- \\
0.17\end{array}$ & $0.03-0.17$ & $0.10-0.30$ & 26 & 22 & $<10$ & 22 & 27 & $<10$ \\
\hline $\begin{array}{l}\text { Osmundastrum } \\
\text { (incl. } O . \\
\text { indentatum) }\end{array}$ & $\begin{array}{l}\text { Triassic } \\
\text { onwards }\end{array}$ & $\begin{array}{l}0.03- \\
0.28\end{array}$ & $0.03-0.31$ & $0.10-0.37$ & $<10$ & $<10$ & $<10$ & $14 *$ & $<10^{*}$ & $<10^{*}$ \\
\hline $\begin{array}{l}\text { O. indentatum }+ \\
\text { Claytosmunda } \\
\text { embreeii }\end{array}$ & $\begin{array}{l}\text { Triassic- } \\
\text { Jurassic }\end{array}$ & 0.14 & $0.28 / 0.25$ & $0.37 / 0.21$ & 42 & 57 & 33 & 51 & 62 & 37 \\
\hline $\begin{array}{l}\text { O. indentatum }+C \text {. } \\
\text { embreeii }+C \text {. } \\
\text { sinica }\end{array}$ & $\begin{array}{l}\text { Triassic- } \\
\text { Jurassic }\end{array}$ & $\begin{array}{l}0.14- \\
0.25\end{array}$ & $0.25-0.29$ & $0.21-0.37$ & 14 & 10 & $<10$ & 29 & 13 & $<10$ \\
\hline $\begin{array}{l}\text { O. indentatum }+C \text {. } \\
\text { embreeii }+C \text {. } \\
\text { sinica }+C \text {. } \\
\text { preosmunda }\end{array}$ & $\begin{array}{l}\text { Triassic- } \\
\text { Jurassic }\end{array}$ & $\begin{array}{l}0.11- \\
0.29\end{array}$ & $0.25-0.29$ & $0.21-0.37$ & 27 & 22 & $<10$ & 35 & 23 & $<10$ \\
\hline
\end{tabular}

2931

$2932 *$ A modern Osmundastrum-O. indentatum clade would receive $\mathrm{BS}_{\mathrm{ML} / \mathrm{LS} / \mathrm{MP}}=11 / 11 /<10$; and including $C$. embreeii $2933 \mathrm{BS}_{\mathrm{ML} / \mathrm{LS} / \mathrm{MP}}=<10 / 18 /<10$ 